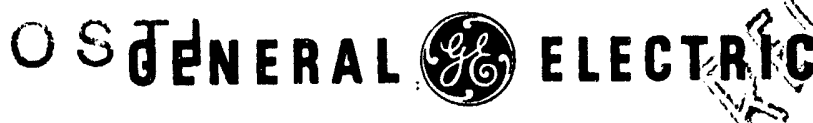

HANFORD ATOMIC PRODUCTS OPERATION - RICHLAND; WASHINGTON W

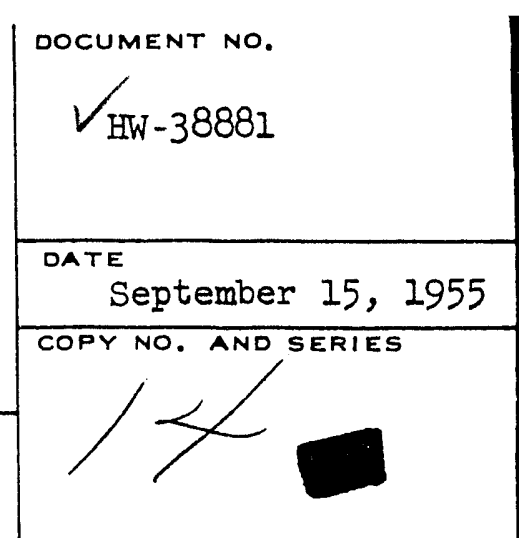

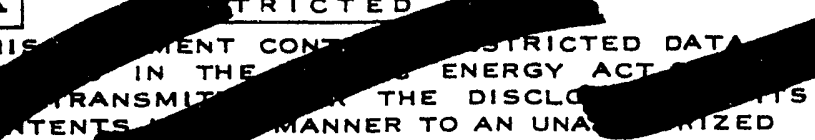
ERSON MIBITED.

OTHER OFFICIAL CLASSIFIED INFORMATION THIS MATERIAL CONTAINS INFORMATION AFFECTING THE NATIONAL DEFENSE OF THE UNITED STATES WITHIN THE MEANING OF THE ESPIONAGE LAWS, TITLE 18, U. S.C., SECS. 793 AND 794, THE TRANSMISSION OR REVELATION OF WHICH IN ANY MANNER TO AN UNAUTHORIZED PERSON IS PROHIBITED BY LAW.

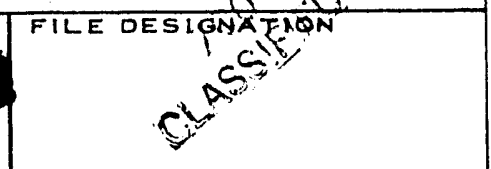

J. B. Fecht, R. T. Jaske,

T. V. Lane, J. O. Ludlow TO IT. WHEN NOT GUARDED AREA CLASSIFIED THIS PRON THIS PRQ OF RE OBT To IM FROM THE RELATED ISS IN THE SPACE PROVIDED BELO LOCKED REPOSITORY WI
TOU HAVE OBTAINED A SH

NAUTHORIZED PERSON MAY HAVE ACCESS LOCKED REPOSITORY WITH I APPROVED EIPT FROM CEIPT FROM
HE LIMITS OF TS TRANSMITTAL TO DUPLICATED MATE AT YOUR PLACE COPIES ARE REQUIRED, ALL PERSONS DOCUMENT ARE REQUESTED

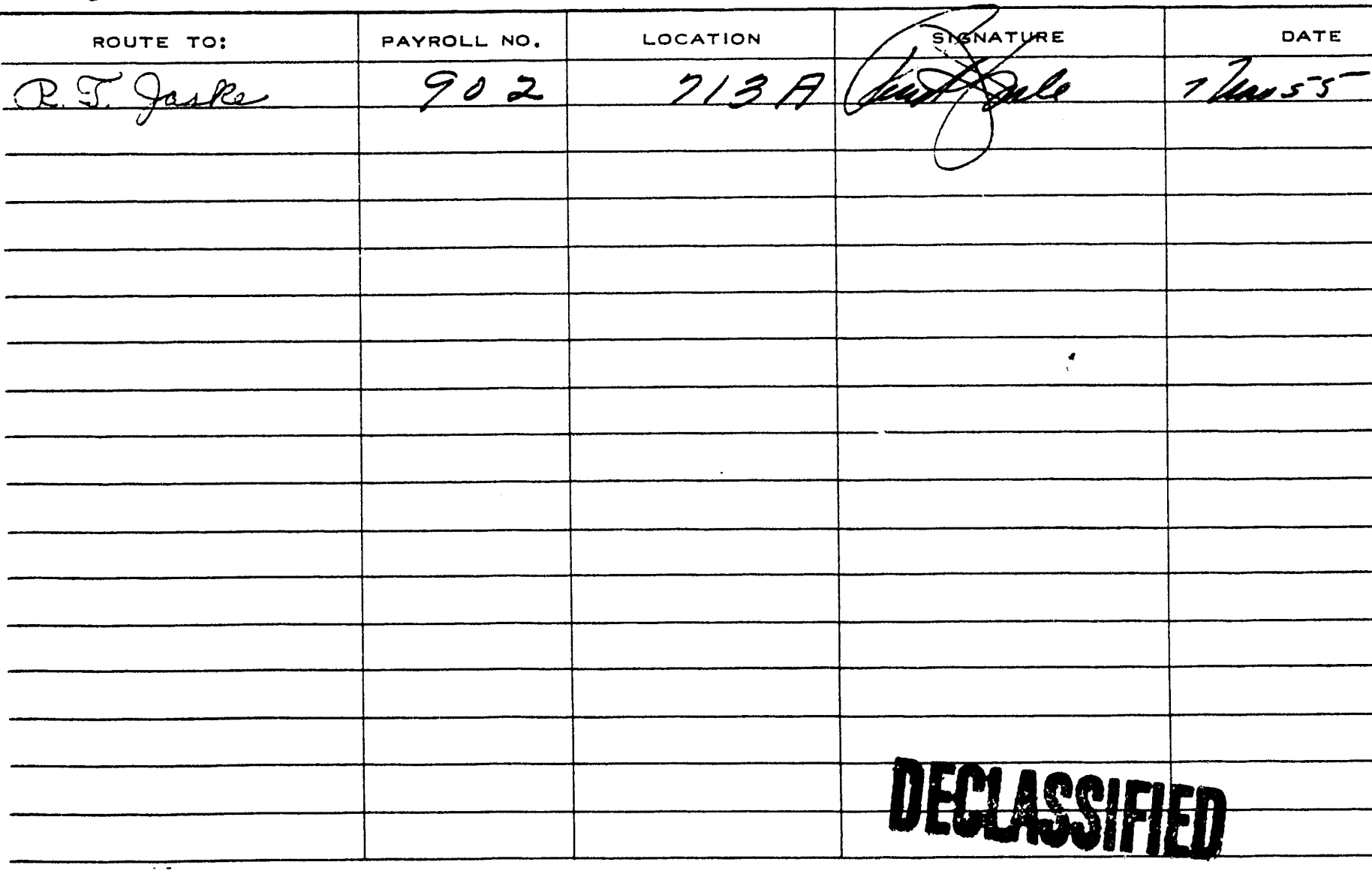

C-3195-MS (1I-54) AEC.ge MICHLANO. WASH

$\min$ 
GENERAL ELECTRIC

COMPANY
1. F. W. Albaugh

2. R. H. Beaton

3. C. R. Bergdahl

4. J. I. Boyd/H. D. Tibbals

5. W. G. Browne

6. H. A. Carlberg

7. W. J. Dowis

8. J. B. Fecht

9. W. F. Garetson/C. F. Gabel

10. A. B. Greninger

11. W. M. Harty

12. T. W. Hauff

13. O. F. Hill

14. R. T. Jaske Guat

15. C. E. Kent/D. R. Gustavson

16. P. D. Lee

17. J. O. Ludlow/T. V. Lane

18. C. A. Lyneis

19. W. K. MacCready
HW-38881

Page 1

This document consists of $\frac{g}{36}$ pages. Copy $1 / 4$ of

20. J. S. McMahon

21. P. R. McMurray

22. E. W. O'Rourke

23. 0. H. Pilkey

24. A. M. Platt

25. W. H. Reas

26. E. I. Reed

27. R. B. Richards

28. C. A. Rohrmann

29. H. P. Shaw

30. 0. V. Smiset

31. R. E. Smith

32. J. H. Warren

33. F. W. Woodfield

34. Extra

35. Extra

36. Extra

37. 300 Files

38. Yellow File

September 15, 1955

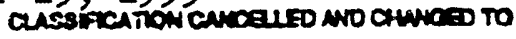
ECLASSIFIEC

W. M. Harty, Head

Separations Design \& Development

762 Building, 700 Area

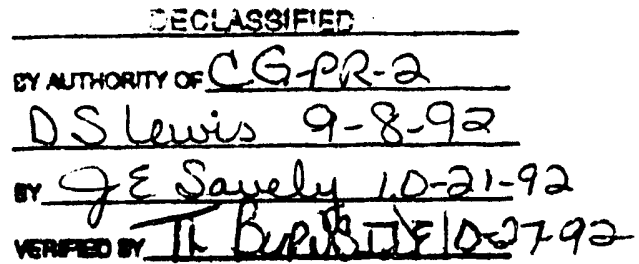

The initial study of a new integrated separations plant has been completed and the results summarized in the attached report. Certain novel process, equipment, and building features have been selected in the bases of the study and will require development and demonstration effort of approximately 18 to 24 months duration depending upon the availability of manpower and money. The preliminary scope is considered feasible. It is believed that a more detalled study would not significantly change the project costs and schedules. The capacity selected was rather arbitrary and within reasonable limits the cap:.tal investment should not be significantly influenced by capacity changes.

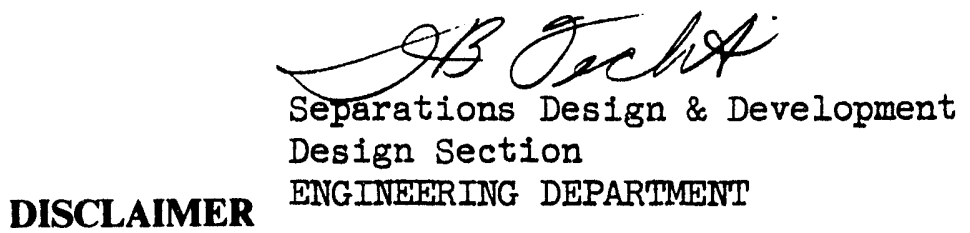

JB Fecht:vsc

This report was prepared as an account of work sponsored by an agency of the United States Government. Neither the United States Government nor any agency thereof, nor any of their employees, makes any warranty, express or implied, or assumes any legal liability or responsibility for the accuracy, completeness, or usefulness of any information, apparatus, product, or process disclosed, or represents that its use would not infringe privately owned rights. Reference herein to any specific commercial product, process, or service by trade name, trademark, manufacturer, or otherwise does not necessarily constitute or imply its endorsement, recommendation, or favoring by the United States Government or any agency thereof. The views and opinions of authors expressed herein do not necessarily state or reflect those of the United States Government or any agency thereof. 


\title{
DECLASFFED
}

\section{A PUREX PROCESS TWO CYCLE PLANT STUDY}

\section{By}
J. B. Fecht
R. T. Jaske
T. V. Lane
J. 0 . Ludlow

September 15, 1955

PROCESS ENGINEERING SUB-SECTION

DESIGN SECTION - EMTGINEERING DEPARTMEIVT

GENERAL ELECTRIC COMPANY

HANFORD ATOMIC PRODUCTS OPERATION

\author{
HANFORD ATOMIC PRODUCTS OPERATION \\ DESIGN SECTION INTERNAL REPORT
}

This document contains information of a preliminary nature prepared primarily for the use of the Design Section and is subject to revision on further checking or collection of additional data. 
B. Process Description

1. General

2. Dissolution

3. Acid Recovery

4. Off-Gas Treatment

5. Partition Cycle

6. Second U Cycle

7. Second Pu Cycle

8. Waste Treatment

9. Organic Treatment

10. Rework

C. Plant Description 15

1. Site

2. Process Builaing - $202 \quad 16$

a. General 16

b. Slug Transfer and Storage 17

c. Slug Charging System 18

d. Product Removal Cell 18

e. Crane and Associated Services 19

f. Miscellaneous Supporting Facilities 19

g. Service Facilities 21 


\section{DECLASSFEED}

$l$.

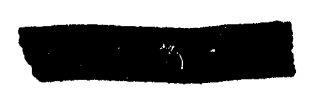

HW -38881

Page 4

3. Equipment and Piping

a. Dissolving and off Gas Cell (A)

b. Feed Preparation and Partition Cell (B)

c. Uranium Cycle Contact Cell (c)

d. Plutonium Cycle Contact Cell (D)

e. Waste Cell (E)

f. Organic Treatment Cell (F)

4. Chemical Tank Farm - 211

5. UNH Storage Facility - 203

6. Control and Analytical Laboratory - 222

7. Waste Facilities

a. Tank Farm

b. Other Facilities

D. Costs

1. Project Costs

2. Operating Costs

E. Timing

1. Design

31

2. Procurement and Construction

3. Project Completion

F. Development Items

1. General Intent

2. Process Features Requiring Development

a. Dissolution

b. Acid Recovery

c. Off-Gas Treatment

d. Iodine Removal

e. Zirconium-Niobium-Ruthenium Removal

f. Waste Condensate Treatment

g. Organic Treatment

h. Effect of Organic Degradation Products on Cont. Calciner 37

3. Mechanical Features Requiring Development Operation 37

a. Slug Handling and Charging

b. In-Iine Pomps

c.- Process Connectors

d. Flexible Jumpers

e. In-Line Samplers and Radiation Instrumentation

f. Column Concatenation and Multiple Operation

g. Pulse Generators

39

h. Coalescers 39

$\begin{array}{ll}\text { V. ACKNOWLEDGEMENTS } & 39\end{array}$

$\begin{array}{ll}\text { VI. BIBLIOGRAPHY } & 40\end{array}$

VII. APPENDICES $\quad 4 I$ 
I. INTRODUCTION

Major additions to separations facilities may be required because of increased reactor power levels, reduced exposures; changes in slug specifications, obso-. lescence of existing solvent extraction plants, or development of new separations processes with lower operating costs. The magnitude of first costs for a separations plant is so large as to discourage production planning which would require an additional major separations facility. Experience in separations design has shown that certain process and equipment changes; if they could be developed, would significantly reduce the capital investment in a separations facility. Accordingly design development for a new separations facility is under way.

II. PURPOSE

The purposes of this document are to present the results of the first separation design study directed toward a new solvent extraction plant and to summarize process, plant, and equipment changes which should be developed to achieve significant capital and operating cost reduction.

III. SUMMARY

Significant capital and operating cost reductions can be obtained in a new separations facility if technical and design developments continue directed at flowsheet, building, and equipment simplifications. For the flowsheet, building and equipment assumed, separations capacity of approximately 400 tons of uranium per month can be obtained in five-and-one-half years for $\$ 52,000,000$. This capital investment is $\$ 3.5-45,000,000$ less than the cost of duplicating existing designs of the Purex Plant. The estimated annual operating cost of the assumed plant is $\$ 5,200,000$ approximately thirty per cent less than what can be expected in the Purex Plant.

The flowsheet, building, and equipment bases included herein would not necessarily be the scope-from which a new separations plant would be designed since technical and design developments and extraneous factors present at the time of project authortzation will dictate scope.

Suitable escalation $(\$ 6,285,000)$ and contingency $(\$ 9,428,000)$ factors have been included in the capital cost estimate and may need to be reviewed should a project develop.

IV. DISCUSSION

The preliminary scope of a new integrated separations facility is described on the following drawings, copies of which are included in the appendix of this report. 
HW -38881

Page 6

Process Sketches

SK-2-1909 Material Balance (secret)

SK-2-1975 Schematic Flow Diagram.

SK-2-1911 Process Flow Sketch - Partition Cycle

SK-2-1919 Process Flow Sketch - Head End Section

SK-2-191? Process Flow Sketch - 2nd Pu Cycle

SK-2-1913 Process Flow Sketch - 2nd.U Cycle

SK-2-1914 Process Flow Sketch - Waste Section

SK-2-1915 Process Flow Sketch - Organic Treatment

Process Equipment Sketches

SK-2-5926 Continuous Dissolver

SK-2-1918 Dissolver off-Gas Absorber

SK-2-1921 Dissolver Off-Gas Cooler

SK $-2-1926$

$\mathrm{SK}-2-1927$

SK-2-1928

SK $-2-1929$

SK $-2-1930$

SK $-2-1931$

Concentrator

Condenser

Cooler

Concentrator Assembly

UNH Concentrator Assembly

SK $-2-1932$

SK-2-1956

SK $-2-1958$

$\mathrm{SK}-2-1920$

SK-2-1978

SK-2-2635

Deentrainer

Acid Stripper Tower

Concatenated Column Package

2A-2B Column Package

Continuous Solvent Recovery

IB \& IC Column Package

Dual Silver Reactor

Process Equipment Arrangement Sketches

SK-2-1955 Process Equipment Arrangement - Dissolver \& Waste Sections

SK-2-1959 Process CelI Arrangement - Cell C - Plutonium Cycle

SK-2-198I Process Cell Arramgement - Cell B - Partition Cycle

Building Architectural Arrangement Sketches

SK-2-1965 Process and Architectural Arrangement - Plans at 4'-0"

SK-2-1967 Architectural and Process Arrangements - Sections

SK-2-1972 Architectural \& Process - Miscellaneous Views

SK-2-1974 Architectural \& Process - Plans at 4'-0" and 16'-0"

Plant Plans

SK-2-1968 Utilities and Services - General Area Plot Plan

SK-2-1969 Building Area Arrangement

Miscellaneous Sketches

SK-2-1947 Dissolver Charging System

SK-2-1960 Flexioie Jumper Study

SK-2-1970 Revised Gilmont Sampler

SK-7-600 Lìrge S1ze Connector Blocks 
The bases used in developing the study, a description of the process and plant and requirements for development and demonstration work are described in the following paragraphs.

\section{A. Bases of Study}

The following assumptions were made to establish the bases for this study.

1. Production Rate

Instantaneous design rate - 15 TU/day

Nominal rate based on plant operating efficiency of $80 \%$ (operating efficlency $90 \%$ and mechanical efficiency $90 \%$ ).

2. Slugs Processed

Aluminum jacketed, natural uranium slugs would be processed. Pile irradiation would result in a slug history of a maximum of $1000 \mathrm{MWD} / \mathrm{TU}$ and $7.5 \mathrm{MW} / \mathrm{T}$. Slugs would be cooled a minimum of 120 days prior to processing.*

3. Use of Existing Facilities

An entirely new separation area would be provided except for utilities which are considered to be adequate in view of the anticipated future shutdown of the T and TBP Plants.

4. Period of Operation

The separations facility would be built for long range operation with production starting in July, 1961.

5. Products

Uranium - Aqueous uranyl nitrate solution

Plutonium - Aqueous plutonyl nitrate solution 55-75 grams/Liter

\section{Flowsheet}

A simplified flowsheet of the Purex Process shown on SK-2-I975 would be used.

7. Capacity Factor and Plant Flexibility

Production capacity in excess of the above stated instantaneous design rate would not be provided within the plant for this study. Actual production capacity increases would be obtained solely by improvement of overall plant operating efficiency and/or future installation of equipment of higher capacity.

* An entlre new study would need to be made if shorter cooling or higher power levels were proposed since solvent treatment and off-gas treatment proposed are based on 120 day cooling and $7.5 \mathrm{MW} / \mathrm{TU}$ power level. 
$\mathrm{HW}-38881$

Page 8

Flexibility for conversion of process would be provided only in the sense that existing process equipment could he removed and other equipment installed. Space has been allocated for mecnanical dejacketing of slugs if such change be required at some future date.

8. Dissolution of Slugs

It is assumed that the continuous and simultaneous dissolution of aluminum jackets and uranium slugs using a mercury catalyst and certain additives will suppress hydrogen evolution to within safe operating limits.

9. Analytical Control

A new laboratory of sufficient size to provide for complete analytical control of the new facility would not be provided as it is expected that ample laboratory space will be available subsequent to the shutdown of the $T$ and TBP Plants.

\section{Timing and Escalation}

The on-stream date of July, 1961, for the new separations facility will be compatible with the attained reactor megawatt comittments of that date. The escalation of $5 \%$ per year to the midpoint of construction in 1959 will be adequate.

\section{Construction Contractor}

The construction of the 202 Building would be by a CPFF contractor and the supporting facilities by lump sum contractors.

12. Development Program

The cost of development and demonstration work required to assure process and equipment performances as desired would not be borne by the project. It is assumed that the data required for design scope could be obtained by July 1, 1957.

\section{B. Process Description}

\section{General}

The basic flowsheet used for this separations plant study is an adaptation of the flowsheet used for the Purex process. Uranium slugs complete with aluminum jackets (or alternatively having jackets of other material removed by mechanical dejacketing) are charged into a continuous dissolving unit and dissolved using nitric acid. Mercury catalyst is used if aluminum jacketed slugs are used. Off-gas treat-. ment is an improvement on the Purex system in that an absorption tower gives essentially complete excess nitric acid recovery. The product 
solution is continuously cooled, pumped alternatively to one of two centrifuges and centrifuged for the removal of extraneous particulate matter--effluent overflowing to a floating feed tank and pumped to the solvent extraction battery. Nitric acid and valence adjustment are performed continuously in the floating feed tank. The solvent extraction battery comprises a partition cycle, a second uranium decontamination cycle and a second plutonium decontamination cycle. The partition cycle $\mathrm{IA}$ column is characterized by an elongated scrub section with external coalescing units to minimize aqueous carryover by the organic extractant. Intercycle concentration is accomplished in a modified long tube evaporator, the product cascading through a continuous product cooler and being fed to the second uranium cycle by means of an in-line pump. The product from the second uranium cycle is batch received, sampled and exported to 224-U Building--utilizing the stripping and concentration facilities available in this location. The second plutonium cycle is that used on the alternate method of the HW No. 3 Purex flowsheet. This consists of introducing part of the $2 \mathrm{BP}$ stream into the upper portion of the $2 \mathrm{~A}$ column--thus enriching the plutonium content of the $2 \mathrm{AP}$ stream and as a consequence the plutonium content of the 2BP stream; flow ratios and amount of recycle are adjusted to obtain a product of 75 grams of plutonium per liter.

\section{Dissolution}

The process used for the dissolving of jacketed slugs as proposed for the New Separations Plant Study is incompletely developed at the present time. Preliminary information obtained at $\operatorname{ORNL}(1,2)$ and at $\operatorname{HAPO}(3,4$, $5,6)$ indicate the general feasibility of dissolution including jackets.

(1) CF-55-2-117, "Continuous Normal Uranium Dissolution," FL Culler, February 17, 1955

(2) CF-55-3-190, "Status Report, Chemical Technical Division, Unit Operations Section," WK Eister, March, 1955. (Verbal information AM Platt, Chemical Development Sub-section.)

(3) HW-30838, "Application of the Mercury Catalyzed Aluminum Technique to the Redox Process," MH Curtis, J Bradford, MK Harmon, December 11, 1953.

(4) HW-32316, "Pilot-Plant Studies of Mercury - Catalyzed Dissolving Aluminum Jacket Fuel Elements," J Bradford, KI Adler, July 1, 1954.

(5) HW-32823, "Proposed Alternate Dissolving Flowsheets for Redox Plant," MH Curtis, MK Harmon, August 13, 1954.

(6) HW-33297, "The Progress Report Chemical Development Unit--September, 1954," FW Woodfield, September 30, 1954. 
The processes used at Oak Ridge were of two types: a tank type unit wherein the slugs were charged intermittently, and a trickle tower type unit also with intermittent slug addition. Higher dissolving rates were obtained with the tank type unit than with the tower type untt; however, the batch addition of comparatively large quantities of slugs to the solution resulted in large intermittent evolution of hydrogen gas. Two different methods are being proposed for minimizing the hydrogen evolution. These are as follows:

1. Operating the unit as a submerged tower to gain the benefits of tank type dissolution and maintaining the level of slugs in the tower three feet above the liquid level to serve as a deentrainer and also to approach continuous addition of the aluminum jackets into the solution. This distributes the hydrogen evolution over the entire dissolving period and avoids peak evolution.

2. Using additions of either sulphate or phosphate ion to depress the hydrogen evolution in accordance with preliminary work of the Chemical Research Sub-Section. This work is being continued and optimum conditions will be determined at a later date.

Because of the lack of complete data regarding the conditions of dissolving it should be realized that the exact flowsheet required will be developed as a result of studies now in process. The dissolver as designed, however, is believed to be sufficiently flexible to allow any foreseeable flowsheet changes for optimum operation.

Solution flows from the dissolver under specific gravity control through an in-line cooler and is elevated by pump to a centrifuge facility. Two centrifuges are used in order to allow continuous operation while allowing clean out by batch means of each centrifuge. Product adjustment is accomplished by metering $\mathrm{NO}_{2}$ gas into the $2 \mathrm{AF}$ feed tank. This metering is not critical, since it is only necessary for an excess of $\mathrm{NO}_{2}$ to be added. Control of the nitric acid in the feed tank is accomplished during operation of the dissolver itself. A combination of increased acid feed and changed liquid level in the dissolver accomplishes this result.

\section{Acid Recovery}

Off-gas from the dissolver is piped to a vertical finned tube gas cooler wherein nitric acid and water vapor are condensed. This solution flows down the tubes co-current with the gas flow, absorbs $\mathrm{NO}_{2}$ vapor, and forms nitric acid which is conducted to an acid receiver tank. The vapors leaving the gas cooler are aumented by a metered air addition to facilitate reoxidation of the No formed by absorption of $\mathrm{NO}_{2}$. The nitric acid absorber is of conventional sieve plate type with a serpentine cooling coil immersed in the 


\section{DECLASSIFED}

$\mathrm{HW}-38881$

Page 11

liquid on each plate. Demineralized water containing mercuric catalyst is introduced at the top of the tower and flows countercurrent to the entering vapor. A side stream is removed from the absorber for purging any chloride content. The nitric acid formed in the absorber is conducted to the same acid receiver as the acid from the gas cooler. This combined acid is pumped back to the dissolver tower under flow control and enters at the top of the liquid section as previously mentioned. Additional acid from the waste section is also pumped into the dissolver tower entertng below the acid mentioned above.

Since the stream intering the dissolver from the waste section contains more acid than is required for dissolution, the excess is purged from the dissolver system as a side stream take off from the acid tank to the dissolver and is piped to the top of the $1 \mathrm{~A}$ column where is serves as part of the scrub solution.

4. Off-Gas Treatment

Off-gas from the absorber is heated by steam in a finned tube heater and conducted to a silver reactor which is constructed to maintain adiabatic conditions throughout its length. The silver reactor is operated until a sample at the mid-point of its packed section indicates maximum allowable iodine concentration, at which time it should be regenerated. This provides adequate backup for "burst" emission of iodine and prevents emission in the event of inadequate regeneration. The off-gas from the silver reactor is filtered in a conventional off-gas filter, air is admitted under pressure control for maintaining proper pressure in the process equipment, and is transferred to the stack via a steam jet.

\section{Partition Cycle}

The function of the partition cycle is to decontaminate the aqueous solution of uranium and plutonium nitrates from fission products and then to separate the uranium and plutonium from each other--the uranium then being transferred to an aqueous solution.

The decontamination of the uranium and plutonium is accomplished by using a suitabde strength of nitric acid as a salting agent and feeding it into the middle of the IA column. Thirty per cent TBP in hydro-carbon diluent recovered from the second cycle is pumped into the bottom of the $1 \mathrm{~A}$ column, flows countercurrent to the descending acid solution of uranium and plutonium and thus selectively extracts the uranium and plutonium into the organic phase, leaving the bulk of the fission products in the aqueous phase. The top section of the IA column--the scrub section-has scrub solution admitted at the top flowing countercurrent to the ascending organic stream containing uranium and plutonium. By means of this countercurrent "scrubbing" residual fission product content in the organic phase is depressed and scrubbed into the aqueous phase. Activity arising from the entrained aqueous phase in the organic phase is minimized by coalescing units installed at strategic locations.. The organic nroduct 
bearing stream from the top of the $1 \mathrm{~A}$ column cascades to the middle point of the $1 B$ column--the partitioning column--wherein the separation of uranium and plutonium takes place.

Partioning of uranium and plutonium depends upon the rapid reduction of the solvent extractable plutonium (IV) to inextractable plutonium (III), by ferrous ion. As in the Redox and Purex processes, sulfamic acid $\left(\mathrm{HSO}_{3} \mathrm{NE}_{2}\right)$ is required to stabilize the ferrous ion and plutonium (III) in the nitrate solution. In high nitrate concentrations in the presence of ferrous sulfamate, uranium remains in the organic phase while the plutonium (III) state is transferred to the aqueous phase. After partitioning, the plutonium is kept in the (III) state by the excess of ferrous sulfamate.

The organic solution from the top of the $I B$ column is conducted to the bottom of the IC column in which it is stripped into the aqueous phase by a countercurrent extraction using another aqueous solution. The organic stream from the IC column cascades to the organic treatment section, while the aqueous uranium stream cascades to the ICU concentrator.

The ICU interstage concentrator is operated as an organic stripper in order to remove residual organic solution from the aqueous ICU. This is accomplished by feeding the aqueous solution onto bubble cap plates intermediately located on the tower. Heat introduced in the concentrator bundles bolls the solution, driving off water and some nitric acid. As this vapor ascends through the bubble cap trays countercurrent to the descending aqueous feed, the nitric acid boiled up in the vapor is recondensed to the liquid and any organic entering with the liquid feed is removed as a vapor. The vapor above the feed point-deentrained from feed solution by using dry bubble cap trays, is conducted to a condenser and then to crib facilities under control of the usual in line flow sampling and radiation instrumentation. Uranium solution leaves the ICU concentrator via a continuous tubular cooler and in-line pump, is throttled by specific gravity control to insure proper uranium content and is conducted to the second uranium cycle.

6. Second Uranium Cycle

Feed to the second uranium cycle--coming from ICU concentrator is adjusted in acid concentration by metering in additional nitric acid. Ferrous sulfamate is also introduced at this point in order to guarantee all of the plutonium being in the (III) state. This stream after the above adjustment is introduced into the middle of the $2 D$ colum which is operated identical to the $1 \mathrm{~A}$ column with the exception that the ferrous sulfamate introduced with the $2 D F$ holds any residual plutonium in the (III) state trus insuring that the residual. plutonium will pass out with the 2DW solution. 


\section{DECUSSFFED}

HW -38881

Page 13

The operation of the 2E column is identical with the operation of the IC column. The dilute aqueous uranium solution is received in a batch receiver, transferred to a batch sampler tank, and is exported to the 224-U Building for stripping and final concentration. The organic leaving the $2 \mathrm{E}$ column--the $2 \mathrm{EW}-$-is pumped via a surge tank to the bottom of the IA column where it serves as the organic extractant.

7. Second Plutonium Cycle

The IBP stream leaving the $I B$ column contains excess nitric acid, small amounts of ferrous sulfamate, small quantities of uranium and small quantities of fission products. Also, the plutonium content is quite low. The function of the second plutonium cycle is to provide a concentrated plutonium stream (approximately 75 grams/liter) free of other metallic ions including fission products, and containing no more than a tolerable quantity of nitric acid. In order to subject plutoniumcontaining solution to a solvent extraction cycle for removal of extraneous ions and acid, it is necessary to first convert it to an organic soluble state. This is accomplished by treating the IBP solution with $\mathrm{NO}_{2}$ gas in a compartmented vessel--nitric acid is also added for adjustment of the salting strength. This solution is fed into the middle of the $2 \mathrm{~A}$ column, organic is introduced at the bottom and extracts the plutonium into the organic phase. This organic phase is scrubbed in the top part of the $2 \mathrm{~A}$ column and is conducted to the $2 \mathrm{~B}$ column where is ascends countercurrent to an aqueous extraction solution. A portion of the plutonium-containing aqueous solution from the bottom of the $2 B$ column is pumped back to the $2 A$ column and by this means increases the concentration of plutonium in the 2AP stream. The increase in plutonium content of the $2 \mathrm{AP}$ stream leads to an increase in the aqueous plutonium solution leaving the $2 B$ column. Full recycle of $2 B$ bottoms is maintained until the $2 B P$ concentration in plutonium is sufficient for introduction into Task 1 of 234-5 Building, at which time an aqueous side stream of product is removed into a batch receiver. This batch receiver is periodically transferred to batch sampling and loadout facilities similar to those used in 202-A Building. The 2BW stream (the organic waste from the $2 B$ column) is pumped to the feed nozzle of the IB column and thus eliminates any plutonium loss at this point.

8. Waste Treatment

The IAW solution is cascaded continuously into a waste evaporator where its volume is reduced to a suttable small quantity for storing under conditions similar to the original Purex scope. $\mathrm{NO}_{2}$ gas or sodium nitrite may be introduced into the concentrator to depress ruthenium volatilization. This waste is received in a batch receiver, transferred to a neutralizer where it is sampled, neutralized with caustic, and transferred to underground storage. The overheads from this concentrator are deentrained from fission product activity by passing

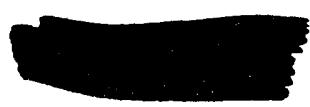




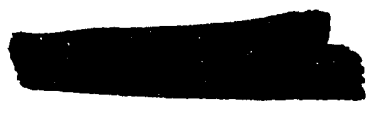

HW -38881

Page 14

through dry bubble cap plates in the deentrainment tower and then introduced into the stripper as a vapor feed. The 2DW and the 2AW are introduced as liquid feeds into the stripper and heat input adjusted so that the bottoms from the stripper will be of the proper acid concentration for the continuous dissolver. Overheads from the stripper are condensed and sent to crib in the same manner as that from the UNH concentrator previously mentioned.

Sump drain collection and disposal are handled as in thë Purex Plant.

9. Organic Treatment

Spent organic from the IC column (ICW) must be treated and prepared before introducing into the solvent extraction battery. This is accomplished in the organic treatment facility. Organic is received in a continuous treatment tank consisting essentially of a vessel containing a shrouded turbine agitator located in a draft tube. Suitable orifices above and below the turbine are provided to regulate the ratio of aqueous to organic circulating through the shrouded turbine. The outer vessel is of sufficient size relative to turbine size so that discreet aqueous and organic phases separate in the outer vessel. Sodium carbonate solution is used as the aqueous treatment agent. The organic mixture is pumped continuously through a decanter to a second treatment tank identical to the first. Aqueous solution from the first treatment tank is removed periodically to an organic wash receiver and jetted to crib. Fresh carbonate solution can be added to the second treatment tank, be removed from there and transferred to the first treatment tank, thus providing countercurrent treatment; or alternately, fresh carbonate can be used for each treatment step. The organic from the second treatment tank is continuously pumped via a decanter to a floating organic feed tank. This feed tank contains continuous pumps which pressurize a header and thus supplies the 2AX and 2DX and the IBX by means of flow meters.

10. Rework

Product uranium solution not up to specification in the UNH sample tank is transferred to the UNH rework tank. The feed pumps in the UNI rework tank feed the ICU concentrator and thus the entire second uranium cycle. Depending upon production rate this uranium rework can be accomplished by blending into the ICU concentrator or by shutting down the first cycle.

Plutonium rework is accomplished by introducing the 2BP plutonium solution into the LAF tank.

Waste that requires reworking upon sampling in the neutralizer is routed to the acid tank and from there into the dissolver.

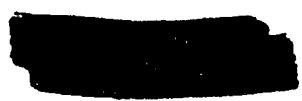




\section{Plant Description}

\section{Site}

Selection of a site in the 200-W Area evolved from a study of the alternatives set forth in HW-37319 (7). The assumptions made are as follows:

1. Bismuth phosphate processes will not be operated.

2. The uranium recovery plant will be shut down.

3. Purex capacity will be raised to goal levels.

4. The $\mathrm{UO}_{3}$ Plant will continue to function.

5. The $224-U$ evaporators will be available for UNH concentration.

6. The 200-W Area will continue to be a more desirable area for cribbing of wastes.

The shutdown of $T$ Plant and $U$ Plant would release the utilities capacity currently assigned to these functions. While Phase III Redox expansion might reduce some of this potential, for the purposes of this study it will be assumed that sufficient capacity will remain without requiring utilities renovation beyond service connections. This makes a $200-\mathrm{W}$ location especially attractive in view of the present high level of service activity carried on at this location.

In addition, it is likely that Purex raw water needs many ultimately consume half of the available system supply. Since a 50-50 water flow between areas is the only way to achieve system flows over 20,000 GPM, it is especially desirable to divide the load in order to use the existing system without further renovation. However, an extensive substitution of water cooling towers as an alternative to swamping would eliminate raw water supply as a factor.

In the past, some credit toward diversification has been realized by dual area operation. Should this feature continue to prove desirable, the construction of this plant in $200-\mathrm{W}$ will balance the production load between 200-E and 200-W Areas.

The plant is located north of the existing T Plant as shown on SK-2-1969 Building Area Arrangement. The following installations will be made as part of the plant:

(7) HW-37319, "Future Separations Capacity," AB Greninger, July 1, 1955.

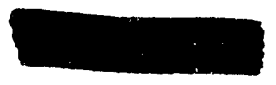




\begin{tabular}{|c|c|c|}
\hline Building & Name & Function \\
\hline 202 & - Process Building & $\begin{array}{l}\text { Storage-Dissolution-Separation } \\
\text { Waste Treatment and Solvent } \\
\text { Recovery }\end{array}$ \\
\hline & & $\begin{array}{l}\text { (b) Make-Up-Service-and Operations } \\
\text { Functions }\end{array}$ \\
\hline 211 & Chemical Tank Farm & Bulk Storage of Liquid Chemicals \\
\hline 203 & Uranium Holdup Vault & Sampling, Holding and Rework Tanks \\
\hline 291 & Fan House and Stack & $\begin{array}{l}\text { Building and Process Air and Vent } \\
\text { Exhaust }\end{array}$ \\
\hline 222 & $\begin{array}{l}\text { Analytical and } \\
\text { Control Laboratory }\end{array}$ & $\begin{array}{l}\text { Routine Analysis of Process } \\
\text { Samples }\end{array}$ \\
\hline 241 & Waste Tank Farm & $\begin{array}{l}\text { Storage For High Salt Radioactive } \\
\text { Waste }\end{array}$ \\
\hline 241 & $\begin{array}{l}\text { Miscellaneous } \\
\text { Facilities }\end{array}$ & $\begin{array}{l}\text { Waste and Product Transfer Lines, } \\
\text { Diversion Boxes, etc. }\end{array}$ \\
\hline
\end{tabular}

The small size of the process building achieved by process simplification and careful integration of components allows use of a site which might be too small for a plant styled on conventional lines.

\section{Process Building - 202}

\section{a. General}

The general arrangement of the process building is shown on drawings SK-2-1965-1967 and 1972 found in the appendix. The process is arranged in three lines with a cross trench at a right angle. This arrangement shortens the building to allow most efficient use of the concrete shielding walls, minimizes excavation and shortens interconnecting process lines. The hot pipe trench intersections can be arranged to provide for future process changes by allowing rerouting, in the manner of junction boxes. The use of an isolated central cell row does increase the length of sampler lines, and requires careful selection of feed line materials, but does offer the choice of going to either wall in arranging process and utility jumpers.

The area above the cells contains the craneway, as in the conventional plant, but the crane rides on the parapet wall in order to reduce the span. The control cab cantilevers from the main girders. Because of the span (105 feet), trusses are required for the roof. Due to contamination difficulties at Redox, a false ceiling of perforated, corrugated sheet metal will be used. This area then serves a dual purpose of providing an inlet air plenum and crawl space for lamp replacement.

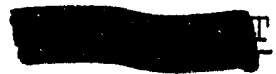


HW -38881

Page 17

In order to economize on concrete and space usage, the shops have been placed at a low level, serviced by elevators and an inclined -ramp. In general, every effort has been taken to utilize excavation and concrete to provide maximum volume for minimum wall and projected areas. The space relationships are listed below.

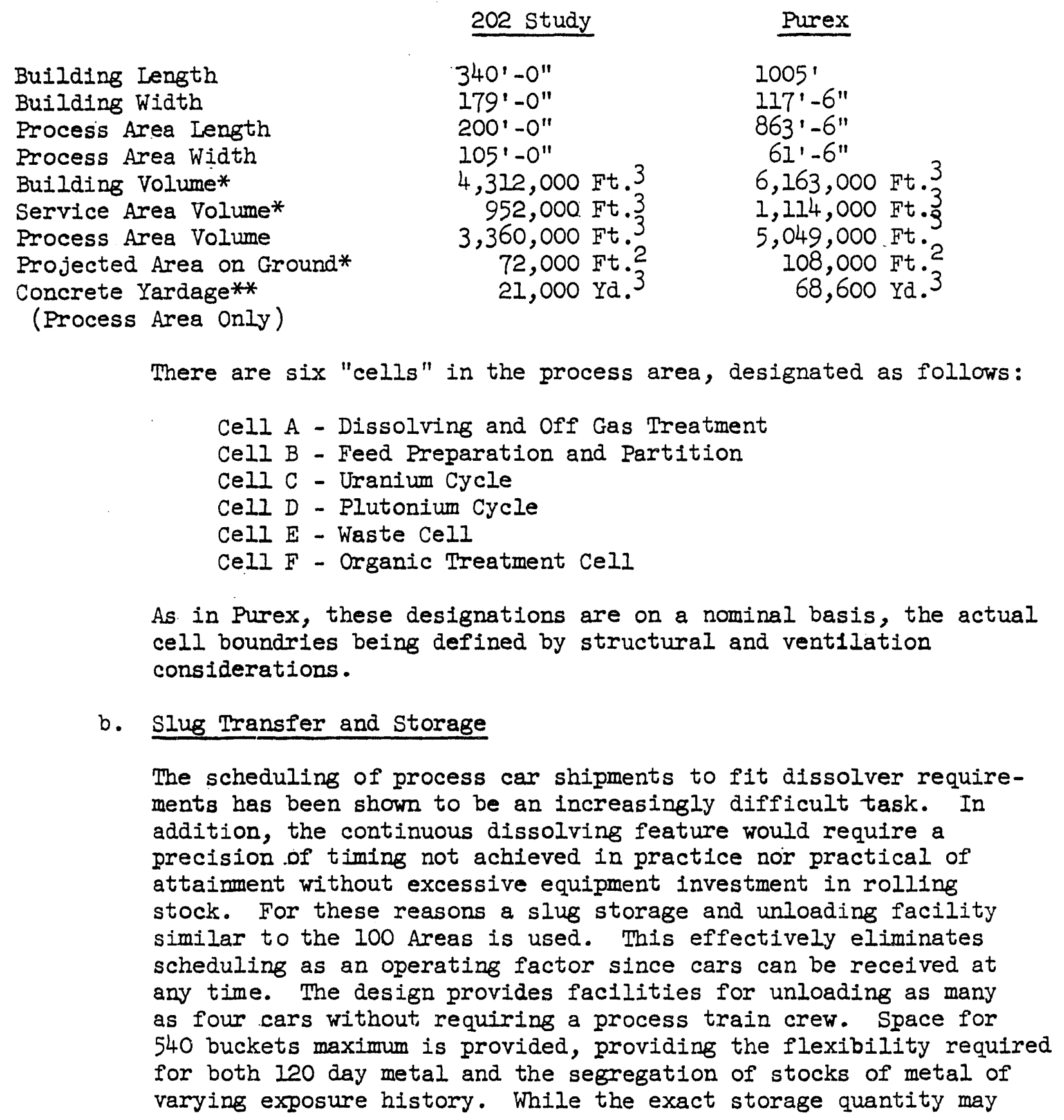

There are six "cells" in the process area, designated as follows:

Cell A - Dissolving and off Gas Treatment

Cell B - Feed Preparation and Partition

Cell C - Uranium Cycle

Cell D - Plutonium Cycle

Cell E - Waste Cell

Cell F - Organic Treatment Cell

As in Purex, these designations are on a nominal basis, the actual cell boundries being defined by structural and ventllation considerations.

b. Slug Transfer and Storage

The scheduling of process car shipments to fit dissolver requirements has been shown to be an increasingly difficult task. In addition, the continuous dissolving feature would require a precision of timing not achieved in practice nor practical of attainment without excessive equipment investment in rolling stock. For these reasons a slug storage and unloading facility similar to the 100 Areas is used. This effectively eliminates scheduling as an operating factor since cars can be received at any time. The design provides facllities for unloading as many as four cars without requiring a process train crew. Space for 540 buckets maximum is provided, providing the flexibility required for both 120 day metal and the segregation of stocks of metal of varying exposure history. While the exact storage quantity may

* Includes Laboratory In Both Cases

** Includes Cells, Covers, Operating, Sample, and Misc. Galleries. 
HW-38881

Page 18

vary from 540 buckets, the cost per bucket is not proportionate to the quantity and will not affect the estimate significantly.

Slugs recelved in cask cars will be unloaded and the buckets placed on the bottom, eliminating the yokes previously used. When required, metal will pass out of storage to an unloading station where charges can be weighed and transferred to the dissolver charging system. Provisions for installation of slug de-jacketing machines are made to one side of the charging area. A small reserve supply of dejacketed slugs could be carried to relieve the criticality of scheduling.

\section{c. Slug Charging System}

This plant uses the skip hoist - batch charging system originally developed for the Redox dissolver plant study, HW-37998 (8). The equipment consists of a lift bucket, guided in an air-tight enclosure, which automatically dumps at a given position. A minimum of moving parts is involved, and graphite bearings (maximum of six) will be used to eliminate lubrication on the "hot" side. The propelling gear motor will operate from the non-restricted side of the canyon and limit switching will be accomplished by an auxiliary geared mechanism.

The entire layout is shown on drawing SK-2-1947, Dissolver Charging System. Slugs in buckets will be transferred to the bucket dumper, proceeding via a vibrating chute, to the skip bucket. The bucket will be raised by a cable to the dumping position, activating the controls for the dissolver seal valve on the way up. Radiation detectors w1ll signal a clear chute and bucket.

All parts of the charging system will be remotely removable, with the holst tube constructed in two pieces to facilitate handing. An auxiliary monorail will be required to assist in the transfer, due to the position of the hoist at the extreme end of the crane travel.

\section{d. Product Removal CelI}

The product removal (PR) room and the PR vault are located adjacent to the Fu cell ("D"). Functionally, the facilities will resemble Purex closely, consisting of two plutonium sampler tanks and a vacuum transfer tank. Access to the process cell will be provided in order to perform contact maintenance.

(8) HW-37998, "Redox Dissolver Facility Study," JB Fecht, RT Jaske, BL Iex, and Jo Ludlow, July 15, 1955. 
In the scoping stage a detailed study would be made to simplify and streamline the can loading and handling technique in order to reduce equipment costs.

\section{e. Crane and Associated Services}

The crane concept for this process building is essentially the same as the previous process cranes which have been constructed, but with some variation in detail. Since the cell equipment length is twenty-six feet or less, no slave crane will be required to remove tower packages. The hook capacity will be based on the cover block weight, as all major pieces of equipment break down into pieces of 10 tons or less. Nominally 40 tons and 10 tons have been selected as main hook capacities, but other sizes, or perhaps a single hook in the 30 ton range might be adequate. The auxiliary hoists for jumpers and wrenches would be the same as Purex.

Due to the long process area span (78 feet) one crane track will be placed on the parapet shield wall. Using the old concept, a 98 foot span would have resulted. The 78 foot span represents an increase from 54 feet as installed in Purex.

The crane cab and auxiliary electrical gear will be cantilevered from the main crane girders. The parapet wall will be constructed of high density, mineral aggregate concrete in order to reduce cab shielding requirements. In addition, location of the rail on the parapet wall permits location of movable shadow shielding above the rail, which may allow a furthur reduction in main cab shielding.

Cab ventilation will follow the Purex design with 10 changes per hour. Blowers will be provided for forced-filtered ventilation of the switchgear and motor generator sets.

Drawing SK-2-1967 Arch.\& Process Arrangement, Sections, 1llustrates the proposed crane installation. Drawing SK-2-1965 Arch. \& Process Arrangement Plan, 1llustrates the area served by the main crane, the maintenance facilities serviced by the crane, and other pertinent features. An auxiliary monorail will be required to move the parts of the slug loading hoist into and out of final position since the main crane hooks cannot reach this item. Furthur study of this item in the scoping phase may indicate that one of the auxiliary hoists, if increased in size may be able to reach this equipment.

\section{f. Miscellaneous Supporting Facilities}

\section{Galleries}

Due to the abbreviated length of the process cells, galleries are located on both sides of the process area. The total length of

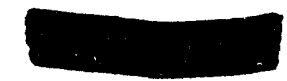




\section{DEDASSFIFD}

$\mathrm{HW}-38881$

Page 20

each of the three service galleries is about 400 feet, and the crane cab gallery being on one side only, about 200 feet. They will be 20 feet wide, and designated as follows: (See SK-2-1965)

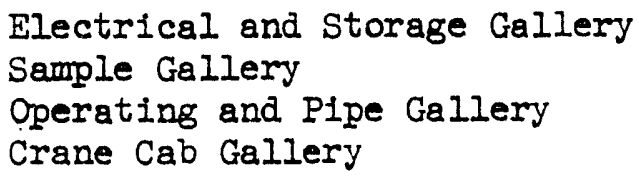

The functions are essentiaily the same as Purex, and equipment of the same nature will be installed.

\section{Piping}

Short intracell transfers between adjacent pieces of equipment are made by direct connections within the cell. All liquid connections below liquid level will use remote flanges. Longer transfers require jumpers to the pipe trench wall, which trenches contain both "hot" and cold process and servicing headers. A system of spare lines will be installed to provide the necessary flexibility. This latter feature is enhanced by the use of the cross tunnel. which permits shorter routings for the spare system. At the tunnel intersections a suitable number of lines will be equipped with kick plates and nozzles allowing re-connection of the spare system in the manner of junction boxes. A suitable number of lines will be carried to a convenient terminal point for future outside connections if process extensions are necessary.

\section{Safety and Housekeeping}

Water fog fire protection and electronic detectors will be installed on the same basis as Purex. Fog sprays are spaced on $9^{\prime}$ to $12^{\prime}$ centers and photo electric detectors in critical areas where solvent is handled.

A built-in, house-type cleaning system will be installed with 30 outlets in a strategic locations on the process cells, PR Room, shops, and maintenance areas. The filtered exhaust air will pass to the ventilation stack.

More extensive application of the breathing air system will be made due to possible contact maintenance in cells "C" and "D" in addition to the outlet locations provided in Purex, connections at 20 intervals within these cells will be furnished. The organic treatment cell being in the main process building will also be covered. 
Protective coatings will be used following established precedent in process cells, hot shop, decontamination cell, regulated shop, PR Room, sample galleries, pipe galleries.

A cell spray systen with nozzles on 15 foot centers will be provided on both sides of each process cell, additional equipment sprays will be located about as in Purex.

\section{g. Service Facilities}

Service Areas

The service portions of the building are located in continuous annexes which adjoin the crane gallery and dissolver sides of the process cell area. The side annex contains all of the facilities usually found on the gallery side of present buildings with the exception of aqueous make up. These include shops, heat recovery, SWP change room, control room, ventilation equipment rooms, offices and lunch room.

The end annex contains the slug transfer and storage equipment, dejacketing area-dissolver charging system (cold side) and aqueous make up. The arrangement of these facilities is shown on the four architectural and process arrangement drawings. SK-2-1965, 1967, $1972,1974$.

Generally the size of the facilities is about the same as Purex. This is required even though a large reduction in process vessel quantity has been made. Those vessels and items which are included become more critical to operation and require a higher concentration of auxiliaries than currently practiced.

\section{Utilities}

High pressure steam (224 psi) will be supplied at two points in the building forming a sectionalized loop running through the galleries and storage and transfer area. Pressure reduction will be accomplished at feed points to headers. Steam will be supplied to the by-pass heat exchanger to provide heat for building ventilation during periods of low process activity.

One 200 SCFM water sealed Nash air compressor for instruments (80-85 psi) and two 500 SCFM, (125 psi) units with $4 \times 12$ receivers for the process system will be supplied. The instrument air system will include recelver $(3 \times 8)$ dryer and back-up connection to the process air system.

Raw water will be provided for cooling water, fire fog and cell washdown. Spent water streams containing high temperature

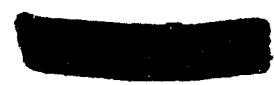


effluent will be combined and routed to the heat recovery system located under the service blower area. In addition, water will be supplied to the various outside facilities. Filtered water will be supplied for the usual purposes of safety showers, area washdown, drinking and toilet facilities and the making of demineralized water.

The electrical distribution system will be modernized to eliminate the intermediate $2400 \mathrm{~V}$ distribution system. A main feed circuit at $13.8 \mathrm{KV}$ will loop the building and laboratory area, and distribution will be made directly to load center type unit substations within the building. Internal distribution will be at $480 \mathrm{~V}$. The secondary $(480 \mathrm{~V})$ system will be tied together to permit isolation of individual load centers equipment without interrupting production. By reducing the number of components greater reliability at lower cost is expected.

Emergency power is available at $2400 \mathrm{~V}$ at the $284-\mathrm{W}$ power house. Provisions for transformation and distribution of emergency power at $480 \mathrm{~V}$ will be made in this facility. The same type of equipment will be supplied as in the Purex system. These include lighting, instrument power and air supply, laboratory exhausts, breathing air, and vital rotating process equipment. A separate $2400 \mathrm{~V}$ emergency generator would be supplied should the present system fail to have sufficient capacity.

\section{Ventilation}

The system will incorporate all current technology developed as a result of operation and testing. The elimination of frequent removal of cell covers from hot equipment which results from continuous dissolving, will greatly assist the cell ventilation. problem by decreasing the air velocities required to control updrafts from thermally hot vessels. The air change rate and general arrangement will be tailored after the Purex system, but additional air quantities will be made available for improved cell ventialation when required.

The process blower room will house two 75,000 CFM central station units arranged in a twin assembly. Each fan will be 150,000 CFM capacity with variable inlet damper control. The arrangement provides a high degree of flexibility in varying supply of air to either the gallery-storage or process areas. Either fan can be shut down or run at partial load.

The service blower room will house a single 75,000 CFM station unit of conventional arrangement. No sparing is furnished, but if required, a twin sectionalized arrangment as in the process 
blower room would be used. The service blower room also contains a 15 ton refrigerated air conditioning system which treats the air supplied to the control room, dispatcher's and shift supervisor's offices.

The heating media for all central station equipment will be glycolwater si uton. Heat. w1.l工 be transferred from process waste water in a heat exchanger similar to $100-\mathrm{K}$. A steam back-up exchanger will be furnished to provide heat during shutdowns. This equipment will be located in a basement area below the service blower room.

Special exhaust systems will be furnished in critical areas such as the sample galleries, organic treatment, PR Room, and regulated shops. These systems will exhaust, through adequate filters, into the main air tunnel.

3. Equipment and Plping

a. Dissolving and Off-Gas Treatment (Cell A)

The general arrangement of the cell is shown on SK-2-1955. Slugs are transferred from the storage area as shown on SK-2-1947. The following major pieces of equipment are located in this cell.

$\begin{array}{ll}\text { Dissolver Tower } & \text { SK-2-5926 } \\ \text { Liquid Cooler } & \text { SK-2-1928 } \\ \text { Gas Cooler } & \text { SK-2-192I } \\ \text { Off Gas Absorber } & \text { SK-2-1918 } \\ \text { Silver Reactor (Off Gas) } & \text { SK-2-1982 } \\ \text { Filter (Off Gas) } & \text { As Purex } \\ \text { Jets (Off Gas) } & \text { As Purex } \\ \text { Jets (Cond. \& Vessel Vent) } & \text { As Purex } \\ \text { Condenser } & \text { SK-2-1927 } \\ \text { Silver Reactor (C \& V. V.) } & \text { SK-2-1982 } \\ \text { Filter (C \& V. V.) } & \text { As Purex } \\ \text { Misc. Jets and Pumps } & \end{array}$

Significant departures from current practice are incorporated in the layout, the single continuous dissolver vessel (SK-2-5926), being the primary item. Process liquid connections below static liquid level will be made with remote flanges in order to extend gasket life. The liquid cooler (SK-2-1921) will be of shell and tube construction.

The cooler will discharge to an "In-line" pump. These units will probably be canned rotor units of the Chem pump variety currently being tested. All liquid connections will be flanged.

Off gas lines will be equipped with a new type of remote connector usable with large lines. for-6ea) Gas will be cooled in the

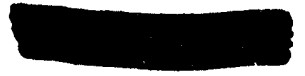


shell and tube cooler (SK-2-1928) and pass to the absorber. The latter WIII be a package unit made of two units shown on SK-2-1918. A pump will return the weak acid from the first stage to the top of the second stage. Serpentine cooling coils and perforated plates serve for cooling and phase contacting. The acid discharge will be pumped to the acid receiver in the uranium recovery cell.

Both the condenser-vessel vent and the dissolver off gas vent systems will use stacked, double silver reactors (SK-2-1982). These units will be operated conventionally, the second. series unit being back up for the first. Discharge gas will be filtered in fibrous glass filters and discharged to the exhaust stack. York mesh will be added ahead of the fibrous glass to assist in deentrainment.

The conventional sump jets, washdown and flushing equipment will be installed. A utility tank is provided for handling vessel dralnage, silver reactor regeneration and sump collection.

b. Feed Preparation and Partition (Cell B)

The general arrangement of this cell is shown on SK-2-1981. This cell contains equipment. for the first decontamination cycle. The following equipment pieces are located in this cell.

IAF Feed Tank

Feed Centrifuges (2)

Slurry Tank

IA Column Package

Partition Column Package

2AF Tank

Recovered Acid Receiver

ICU Concentrator

Utility Tank

Misc. Pumps \& Jets
Standard Tank

As Purex

Standard 2500 Gal. Tank

SK-2-1956

SK-2-1978

Standard Tank

Standard Tank

See Below - SK-2-1929

Standard Tank

Dissolver solution will enter the cell from a wall nozzle and flow to elther of the centrifuges. Two are required because of the cleanout and frequent outages associated with this type of equipment. Centrifuge slurry will be transferred to the slurry tank and jetted to waste.

Aqueous feed will be made up and acidity adjusted in the lAF tank which will be a standard Hanford Class I tank. Feed will be pumped by an open type tank pump to the IA column. This column consists of three concatenated sections with large (14") interconnecting lines sized to minimize pulse loss. The feed points are located to provide about fifteen feet of extraction section and sixty feet of scrub section. Drawing (SK-2-1956) 1llustrates one possible arrangement. The proposed tower package will also be interchangeable with the $2 D$ column in order to minimize spares. 
Partially decontaminated $U$ \& $P u$ in the organic will then be pumped to the partition column package consisting of IBS-IBX and $1 \mathrm{C}$. This package is preassembled to reduce the number of connectors to a minimum. Drawing SK-2-1978 illustrates the component arrangement. The IBS column in the package will have a beaver tall to provide safe geometry in the event of concentration of Pu aqueous solution at the IBS feed point. A separate small pulser will be synchronized to amplify the pulse in the 1BS coiumn. The balance of the package (1BXIC and IA Column) will be pulsed from one large pulse generator. The tops of each column will be continuously bled to the utility tank in " $\mathrm{B}$ " cell, in order to eliminate air and consequent pulse loss.

The aqueous from the IBS goes to a conventional 2AF tank.

The ICU concentrator is shown on SK-2-1929. It is intended that the assembly be built up of standard parts to minimize sparing. This unit consists of a special dunnage, a standardized cooler, two right and two left hand standardized unit concentrators, and a standardized tower. The individual units are shown on SK-2-1926, SK-2-1927, SK-2-1928, and SK-2-1930.

The conventional sump jets, washdown and flushing equipment will be installed. As for cell "A" fire detection units will be located in all parts of the cell utilizing TBP diluent.

\section{c. Uranium Cycle Cell, Contact-Cell "C"}

The equipment is arranged and selected on the basis of allowing for contact maintenance and remote dis-assembly if required. Following this basis, the tolerance of nozzle location will be allowed to run to ordinary field run specifications, probably $\pm 1 / 4 "$. Flexible jumpers varying in material to suit the conditions, will be used. Connections within package units will be standard ASA flanges. Standard remote connectors will be used for all connections to the package. This type construction gives the option of contact maintenance or of remote dis-assembly in the event effective decontamination is not realized.

The following equipment pieces are located in this cell:

2D Column \& Pulser

2E Column

2EW Tank

Acid Tank

Misc. Pumps \& Jets. 
The $2 D$ column will be a three-piece package identical with the IA column shown on SK-2-1956. As stated above, greater tolerances on this unit will be allowed. The pulser and auxiliary equipment will also be suplicates of the lA group, arranged for contact maintenance. It is possible that a different plate assembly might be desirable, but this item can be incorporated into the final design. In turn the $2 E$ column will be the same as the $1 \mathrm{C}$ except that it will be individually mounted as in Purex practice. As in the first cycle, only one pulse generator will serve this battery.

The organic from $2 \mathrm{E}$ will be collected in the 2EW tank, sampled, and pumped to cell " $B$ " where it will be fed to the IA column as organic feed. A field tolerance tank similar to those to be supplied to the organic cell will be used. The same construction is employed for the acid tank which collects recovered acid for re-use in the dissolver cell "A".

The usual sump jets, washdown and flushing equipment will be installed, subject to increased number in support of the contact maintenance objective.

d. Plutonium Cycle Cell - Contact-Cell "D"

With the exception of pumps, pulse generator, jets, and controls, all equipment will be contained in a single package consisting of the $2 A S-2 A X-2 B$ columns and the $2 B$ receiver. As practiced in Purex, all piping will be critically safe tor all concentrations. Access to the cell will be through cover block, or the PR Room. All equipment and piping will follow the philosophy described in cell " $C$ " above. Other than the recycle feature, the equipment will closely resemble Purex package equipment. See drawing SK-2-1959 for an arrangement of this equipment and SK-2-1958 for details of the columnreceiver package.

e. Waste Cell ("E")

The waste concentrator and acid tower will be built up of standardized pieces of equipment as intended for the ICU concentrator. Each of these will consist of a custom dunnage, standard cooler, condenser, and concentrator units and a custom tower. The individual towers for the acid tower and waste concentrator are shown in drawing SK-2-1932 and SK-2-1931 respectively. Standard class one tanks will be used for the waste receiver, neutralizer and sump collector tanks. 
$\mathrm{HW}-38881$

Page 27

f. Organic Treatment - Contact-Cell "F"

The equipment consists of four 5,000 gallon tanks with heads to accomodate the turbine type solvent treatment contactor shown on SK-2-1920. The basic tanks will be interchangeable with those in cell "C", and constructed so that either standard flanges or nozzle adaptors can be used. The facility will bear exterior resemblance to the Purex solvent recovery cell with the exception of the 10 column and centrifuges. Its location under the crane maintenance gallery permits efficient use of space and still permits access to the main crane for removal of equipment. Make up organic will be prepared in the chemical tank farm (2II).

4. Chemical Tank Farm - 211

The chemical tank farm is located southwest of the 202 Building. The tanks, their use, capacities, and materials of construction are given in the table below:

Service

Nitric Acid - $60 \% \mathrm{HNO}_{3}$

Nitric Acid - $60 \% \mathrm{HNO}_{3}^{3}$

Caustic - $50 \% \mathrm{NaOH}$

Demineralized Water

TBP Diluent

TBP

Laboratory Acid - $\mathrm{H}_{2} \mathrm{SO}_{4}$ Solvent Mix Tank

Capacity
$100,000 \mathrm{Gal}$.
$100,000 \mathrm{Gal}$.
50,000 Gal.
$50,000 \mathrm{Gal}$.
$65,000 \mathrm{Gal}$.
$30,000 \mathrm{Gal}$.
1,000 Gal.
5,000 Gal.

Material

$304 \mathrm{~L}-\mathrm{s} / \mathrm{s}$

$304 \mathrm{~L}-\mathrm{s} / \mathrm{s}$

Carbon Steel

Aluminum

Carbon Steel

Carbon Steel

Carbon Steel

Carbon Steel

The water demineralizer of $50 \mathrm{gpm}$ capacity will also be located in the 211 facility. The equipment will be anion and cation exchange type as installed in 211-A consisting of rubber lined exchanger tanks, pumps, and regeneration chemical storage tanks.

All storage facilities will be suitable for receiving either truck or rail shipments in keeping with policy.

5. UNH Storage Facility -203

Output from the uranium recovery cycle will be fed through underground Iines to the intermediate storage facility. Storage is kept to a minimum in order to minimize holdup of the dilute $14 \%$ UNH solution in the $2 E U$ stream. The facility will be comprised of a vault containing three tanks per flowsheet SK-2-1913. Each tank will have a capacity of 20,000 gallons and be equipped with agitators, pumps, and cooling coils. While a contact maintained facility remote from 202, all controls will be centralized in the 202 central control room. 
Flow from the $2 E$ column will be received in the UNH receiver tank, sampled from the sample tank and routed to 224-U through an overhead steam chased transfer line. Off'standard material will be collected in the UNH re-work tank and re-routed in the ICU concentrator feed stream for blending and re-work.

6. Control and Analytical Laboratory - 222

While the need for this facility has not been firmly established, the following description is included in order to define this item should it be required. Continued development of in-line instrumentation may reduce sampling requirement to a level capable of being handled in 222-T and/or 222-S. A separate facility connected to the sample galleries by a tunnel is a proposed solution to a facility of undefined scope, and permits lump sum contracting for the facility should development work fail to support the more optimistic goal. For this reason, the cost of the laboratory is not included in the total cost estimate, but carried as an addendum.

Using the current methods of analysis, and on a basis of analyzing $1 / 2$ the number of samples as Purex, a laboratory of about $60 \%$ of the Purex laboratory floor space would be required. This would consist of the following:

\author{
2 Hot Laboratory Rooms \\ 1 Cold Laboratory Room \\ Counting Room \\ Infra-Red \& X-Ray Rooms \\ Decontamination Room \\ Office \& Storage Space \\ Men's \& Women's Lockers and Change Facilities \\ For 9 Workers Per Shift \\ Interconnecting Thunel to 202
}

Laboratory utilities would be handled as in the Purex laboratory utilizing a second floor equipment room. Service connections to 202 for water, steam, instrument air, $60 \% \mathrm{HNO}_{3}$, air sampling and breathing air would be made. Internal utilities would include ventilation, vacuum, distilled water, methane, oxygen, and propane gas.

Laboratory wastes would be disposed of in a conventional manner, some simplification over the Purex laboratory being expected.

\title{
7. Waste Facilities
}

The general arrangement and location of waste facilities is shown on the plot plan SK-2-1968. 
$\mathrm{HW}-38881$

Page 29

a. Tank Farm

Routing of process wastes, condensates, and UNH streams is from the west side of the building via an exit encasement containing 15 three-inch stainless steel lines. Five lines are separated and stubbed in a separate encasement just outside the building for future tie-in to an additional diversion box or other process facilities. Three more Ines are separated to the 203 Area and the remaining seven lines enter a diversion box west of the building. Five Somastic-coated three-inch stainless steel lines run from this diversion box to the tank farm. Two three-inch stainless steel lines, Somastic-coated, provide a tie from the building diversion box to the 241-T-153 diversion box for future transfers from other farms to $241-A$ for evaporation or from the building to other farms. Encasement construction according to the recommendations contained in $\mathrm{HW}-24500$ is recommended where applicable. Standard Hanford cathodic protection should be provided.

A waste tank farm containing six one-million gallon tanks is shown to the northwest. Distribution piping should be provided to route waste directly to each tank via valve box. Vapors are collected from each tank in a common header and are conducted to a re-boiler evaporator, with secondary vapors going to an atmospheric condenser. Condensate from the condenser will normally be routed to the swamp area. An activity alarm should be placed on the condensate stream to divert it either to crib or back to a waste tank according to the activity level and limits set. Tie-in lines to both cooling water sewer and process waste crib are shown.

Waste tank construction should be reviewed to insure optimum costs under the activity and temperatures to be sustained.

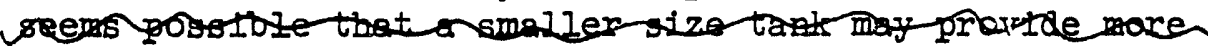
wonomic stoxage. In either case, air-lift recirculators should be provided.

b. Other Facilities

Waste cooling water from the 202 Building process coils and condensers is shown routed via a 24 -inch V.C.P. Iine to the present $T$ Plant swamp area, which will be adequate for flows up to $3.5 \times 10^{6}$ gallons per day. Such disposal is predicated on the basis of $T$ Plant's being out of service. Should standby status of $T$ Plant be such that operation might be required, or If capacity of the new plant cquld be expanded to require disposal of greater than $3.5 \times 10^{6}$ gallons per day, a cooling tower installation would be recommended for recirculation of the cooling water. 


\section{DECAMSHFED}

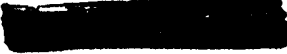

HW -38881

Page 30

Overflow from continuous water change in 202 Building slug storage and transfer basin is assumed to be normally $100 \mathrm{gpm}$ and would normally go to the waste cooling water sewer via a 12-inch V.C.P. line. A weir box is provided for diversion of this stream to the process condensate crib in event the basin becomes significantly contaminated.

The following waste cribs are provided, line-type cribs being chosen for all continuous flow cribs. All crib lines should have stubs for connection of replacement or additional crib space.

\begin{tabular}{|c|c|c|c|c|}
\hline Stream & Flow-gpm & Crib No. & Size & Location \\
\hline $\begin{array}{l}\text { Process Condensate } \\
\text { (Tank Famn Condensate } \\
\text { and Basin Wate un } \\
\text { Temporary Basis) }\end{array}$ & $\begin{array}{l}100 \\
(200 \text { on } \\
\text { temporary } \\
\text { basis) }\end{array}$ & 5 & $10 \times 2900$ & $\begin{array}{l}\text { Northwest, outside } \\
\text { area fence }\end{array}$ \\
\hline Steam Condensate & 225 & 6 & $10 \times 330$ & $\begin{array}{l}\text { Northeast, outside } \\
\text { area fence }\end{array}$ \\
\hline Organic Clean-up & Intermittent & 2 & $20 \times 20$ & $\begin{array}{l}\text { West of building } \\
\text { inside exclusion } \\
\text { area }\end{array}$ \\
\hline $\begin{array}{l}\text { Diversion Box and } 203 \\
\text { Area Sump Drainage }\end{array}$ & Intermittent & 3 & $30 \times 30$ & $\begin{array}{l}\text { West of diversion } \\
\text { box, inside exclu- } \\
\text { sion area }\end{array}$ \\
\hline $\begin{array}{l}\text { Stack, filter, and } \\
\text { plenum drains }\end{array}$ & $\begin{array}{l}10 \\
\text { (may be low) }\end{array}$ & 4 & $10 \times 150$ & Southwest of stack \\
\hline Laboratory Wastes* & 20 & 1 & $10 \times 300$ & North of laboratory \\
\hline
\end{tabular}

D. Costs

1. Project Costs

The project costs were estimated from the study drawings included in the appendix, and other supplementary notes.

As shown in Table $I$, the estimated total project cost for the new separation facility is $\$ 52,000,000$ excluding the analytical laboratory. This cost includes $\$ 2,629,000$ for spare parts, $\$ 6,285,000$ for escalation of 1955 prices to the midpoint of projected construction program

* A separate item--costs included in laboratory 
HW -38881

Page 31

expected to occur in 1959, and $\$ 9,428,000$ for construction contingencies. The project cost is based on CPFF construction of the process building

- and Iump sum contracting of all supporting facilities such as the waste farm, ventilation exhaust system, chemical tank farm, cribs, steam, water and electrical lines, etc. It is expected that some reduction in total project cost might be obtained by lump sum construction of the process bullding; however, it is not considered practical in view of the preliminary status of the study to obtain a positive cost reduction.

\section{Operating Costs}

As shown in Table II, it is estimated that the annual operating cost of the new separations facility during the first year of operation would be $\$ 7,830,000$ including labor escalation under the present operating contract plus 6 per cent for the 1961-1962 operating period, $\$ 364,000$ for materials price escalation, $\$ 474,900$ for other contingencies and $\$ 2,600,000$ for amortization of the facility over a period of 20 years. It is to be noted that the value of major equipment replacements and uranium and plutonium losses are not included.

E. Timing

1. Design

It is presently anticipated that the majority of detail design on future project work will be placed with architect engineer firms. Therefore, it has been assumed for purposes of obtalning a design cost that the detail design will be accomplished by an architect engineer firm. In Figure $I$, the schedule for design by the Ceneral Electric Company is shown for comparison purposes only.

A two year development period is considered necessary in view of the lack of proven technical data on much of the equipment used in the present study. As shown in Table I scope design will require eight months and detail design by an architect engineer 20 months or a total of 28 months.

2. Procurement and Construction

The procurement and construction schedules are included in the composite engineering schedule (Figure I). As shown, procurement and construction would require 26 months with CPFF construction startius 12 months after the start of design scope. The Plant based on CPFF construction of the process building would be accepted by the using department Jamuary, 1961, or 40 months after the start of design scope and on-stream July, 1961, or 46 months after start of design scope. Consideration of construction of the entire facllity on the basis of lump sum contracting would indicate a final on-stream date of May, 1962. 
TABLE I.

PRO JECT COST ESTIMATE

FOR A PUREX PROCESS TWO CYCIE PLANT STUDY (9)

\section{Item}

CPFF CONTRACTOR:-

Area Clean-Up \& RMU Services

Temporary Construction

Process Building:

Structure

Services

Spare Parts

Process Equipment

Tools, Communication, etc.

FIXED PRICE CONTRACTOR:

Waste Tank Farm

211 Tank Facility

291 Facility

Proc. Iines to 224-U

203 Stor. Vault

Misc. Area Facilities

Utility Add'ns. \& Extensions

All Other Outside Proc. Lines

Sub-Total

Other Direct Costs (5-2I-5\%)

Payroll Burden (5\%)

Total Direct Costs

CPFF Indirect (17\% of Labor)

CPFF Fee (3\% of Labor)

Reserve for close out ( $2 \% \mathrm{CPFF}$ )

Constr. Field Supv. (5\% of Total)

Sub-Total

General Overhead (3\%)

Escalation (20\%) 4 yrs at $5 \%$

Contingencies $(30 \%) *$

Misc. Work Orders

Start Up Costs

Design

Amount, $\$$

$\$ \quad 153,000$

950,000

$3,300,000$

$2,932,000$

$1,409,000$

$9,781,000$

130,000

$1,980,000$

658,000

943,000

170,000

700,000

97,000

568,000

878,000

$\$ 24,649,000$

$2,666,000$

450,000

$\$ 27,765,000$

1,$612 ; 000$

284,000

373,000

$1,390,000$

$\$ 31,424 ; 000$

943,000

$6 ; 285 ; 000$

9,$428 ; 000$

$170 ; 000$

250,000

$\$ 48,500,000$

$3,500,000$

$\$ 52,000,000$

Estimated Project cost

* Includes all contingencies normally found in a Project Proposal estimate but does not include deviations from the bases of the study (Section IV-A) or other major process and facility. changes.

(9) Letter, "New Separations Plant," J Fecht from $G F$ Gabel, Estimating and Unit Cost Unit, September 29, 1955. 
TABLE II

ANNUAL PRODUCTION COSTS

A PUREX PROCESS TWO CYCLE PLANT STUDY

Direct Labor*

Indirect Labor*

Shop Tools \& Supplies

Maintenance

Rent, Light, \& Heat

Laundry

Freight, HWRR

Electricity

Other Services

Water, Steam \& Sewage, Incl. Process

Radiation Monftoring

Plant Engineering

Process Unit - Mfg.

Analytical

Direct Materials

Sub-Total, Direct Mfg. Cost

Waste Storage

Process Assistance

General Administration

Sub-Total, Mfg. Cost

Labor Escalation**

Material Escalation***

$10 \%$ Contingency

Total Annual Production cost

Amortization of Plant - $20 \mathrm{yr}$. basis

Total Annual Operating Cost

Rounded $\begin{array}{r}518,200 \\ 258,400 \\ 60,000 \\ 933,600 \\ 20,000 \\ 20,000 \\ 50,000 \\ 5,000 \\ 35,000 \\ 250,000 \\ 106,200 \\ 29,000 \\ 84,000 \\ 210,100 \\ 870,900 \\ \hline \$ 3,450,400\end{array}$

$$
\begin{array}{r}
170,100 \\
96,400 \\
517,600 \\
\hline \$ 4,234,500 \\
149,800 \\
364,900 \\
\hline \$ 4,749,200
\end{array}
$$

$\frac{474,900}{\$ 5,224,100}$

$\frac{2,600,000}{\$ 7,824,100}$

$\$ 7,830,000$

* Indirect and Direct labor items are a minimum figure for a three cycle ( $1 A-I B-1 C, 2 D-2 E, 2 A-2 B$ ) Separations plant. This figure will increase if there is any increase in cycles, any unusual maintenance, solvent cleanup or waste tank farm problems.

* Labor costs include labor cost increases up to and including 1960 according to the 1955 agreement. Labor escalation will be $6 \%$ in order to bring labor costs to the 1961-1962 level.

** Materials cost escalation will be at $3 \%$ per year, or a total of $21 \%$ to bring materials cost to 1961-1962 level. 
FIGURE I

COMPOSITE ENGINEERING SCHIEDULE

A PUREX PROCESS TWO CYCLE PLANT STUDY

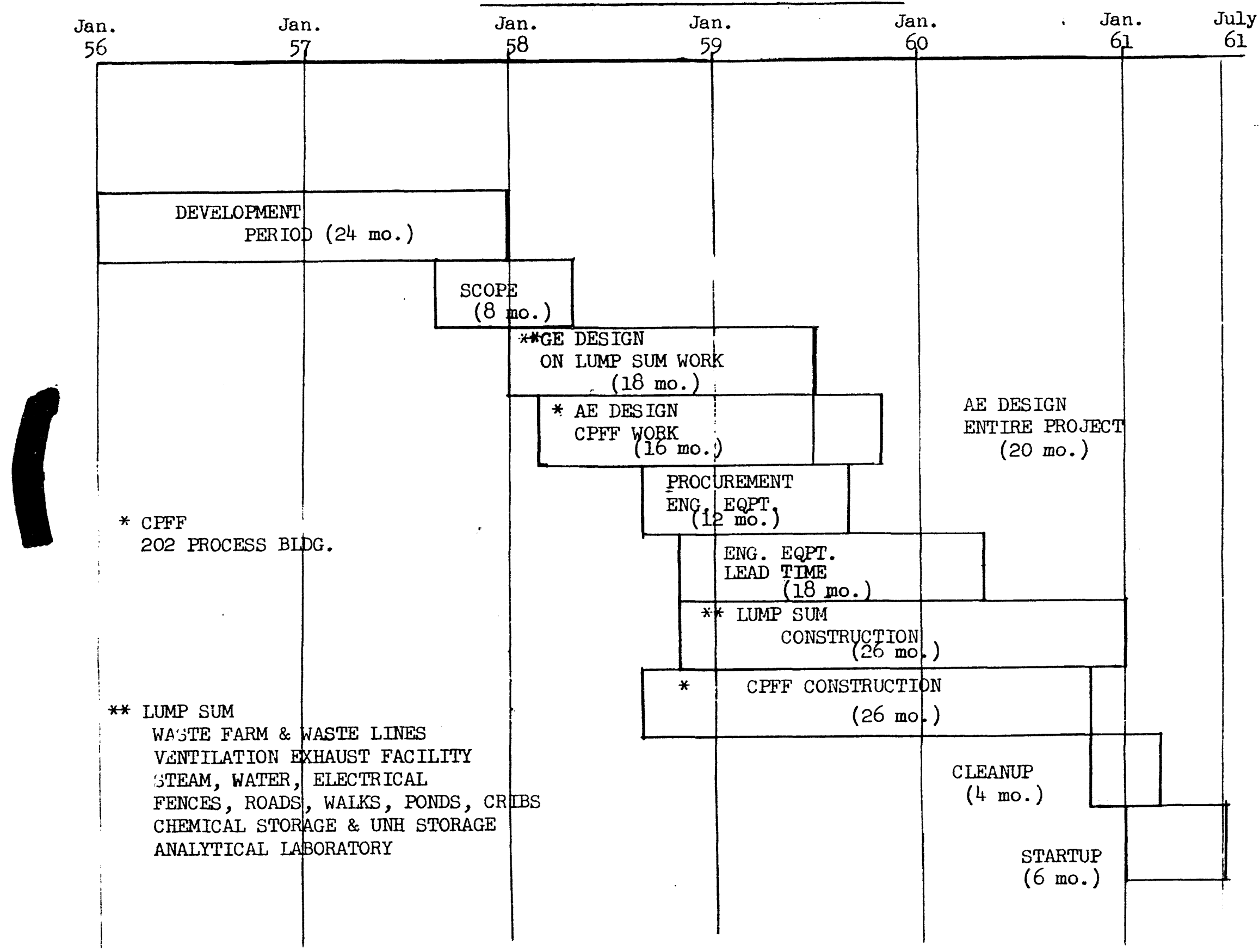

Jan. 
HW -38881

Page 35

\section{Project Completion}

As shown in Figure $I$, the plant would be on-stream at the rated capacity 46 months after the start of scope. Six months were allowed for the using department to complete tank and instrument calibrations, line flushes, cold runs, hot runs, etc. Two months overlap with construction are included in the six months.

\section{F. Development Items}

\section{General Intent}

In the development of this plant design, a number of assumptions regarding the plant capacity and mode of operation were made based on limited or only indirectly related data. This is in conformity with the purposes of the study which included establishment of worthwhile gools both process and plant-wise.

2. Process Features Requiring Development

a. Dissolution

There is no similar process currently being used. Data obtained from trickle type units at ORNL and a two-stage system at ARCO were scaled up to the plant target size although the data from the referenced sites were obtained using solid U-AL alloy, and part obtained using Hanford slugs. The following list of items sums up the unknowns:

1. The effect of leaving a dry heel of metal above the solution level subject to the dissolver off gas has not been experimentally established.

2. The effects of sulphate addition for the control of hydrogen evolution in a mercury catalyzed dissolving process is not established.

3. Data on continuous dissolution rates per unit metal heel are not known with certainty.

b. Acid Recovery

This process envisions acid recovery on a more efficient level than ever before accomplished. In addition, equipment height is IImited to 26 feet. The two stage tower, one unit of which is shown in SK-2-1918, uses a plate cooling grid design which will require experimental verification. 
$\mathrm{HW}-38881$

Page 36

c. Off-Gas Treatment

Due to the short period of time, no complete study of the relative efficlency or economy of two stage silver reactors versus caustic scrubbiag and one stage reactors could be firmed up, particularly since the latter depends to some degree on the acid absorber efficiency. The large amount of work currently going forward on lodine removal should provide a firm basis by the time the other unknowns are established.

Preliminary laboratory data (10) indicate that the presence of mercuric ion in dissolver solutions in concentrations as used in the assumed flowsheet will suppress lodine evolution by 90 per cent. Verification of this action in plant scale equipment would result in minimized silver reactor requirements.

d. Iodine Removal

The facilities shown for the removal of lodine are based on operating data from the existing separations plants. Research investigations are continuing with a goal of determining optimum conditions, reagents and equipment for iodine removal. This work should be continued and the results obtained used to modify the process and equipment as given in this proposal.

e. Zirconium-Niobium-Ruthenium Removal

Decontamination in a solvent extraction separations plant as a general rule is limited by zircontum - nlobium and ruthenium removal, depending on the solvent extraction conditions. Research and development work is being directed towards optimizing methods for removal of these fission products by solvent extraction means. It is possible that the plant as outlined herein would accommodate the changing flowsheets that may be desirable to provide maximum decontamination. Such changes might include multiple scrub sections perhaps using scavenging chemicals. If any sizable changes in equipment for the solvent extraction battery are required, they would be outside of the scope of this proposal.

\section{f. Waste Condensate Treatment}

The waste section of the present proposal envisions cribbing condensate from the $1 \mathrm{~A}$ waste after it has been boiled in a concentrator, deentrained by dry plate separators, and stripped of acld in an acid stripper tower. Data are not ava1lable at present as to whether this treatment will provide condensate of sufficient low activity to allow cribbing. It is possible that either equipment development or auxillary treatment such as scavenging may be necessary in order to secure sufficiently

(10) HW-21103, "Retention of Iodine in Process Solutions by Mercuric Salts," CH Holm, June 15, 1951. 
low activity for cribbing. This should be demonstrated before the necessity arises for reducing this proposal to actuality.

B. Organic Treatment

The organic treatment used is expected to be operated with contact maintenance--based on 120 day cooling for the decay of iodine. The other factor which might negate against contact maintenance in this area is fission product build up (zirconium-niobium-ruthenium). The treatment unit proposed on this flowsheet is the unit developed at the Savannah River Separations Pilot Plant and to date has not had extensive "hot" testing. Some data will be available from Savannah River regarding performance of this unit. However, a test facility should be set up at Hanford and operated.

h. Effect of Organic Degradation Products on Continuous Calciner Operation

It is proposed to export the UNH solution to the 224-U Building for stripping and concentrating. Information now available indicates that it is possible that a concentrate formed under such conditions would cause foaming in the batch calcination pots. Operation of the test continuous calciner to date has not under any conditions presented a foaming problem. However, tests should be made to demonstrate the feasibility of storing unstripped, dilute UNH solution for periods of two to three days followed by stripping and concentration before serving as calciner feed. It is possible that other deleterious side conditions may arise because of this treatment.

\section{Mechanical Features Requiring Development}

In conformalce w1th process objectives, some development of the mechanical features is required. This phase is expected to be in the nature of confimation checks on a full scale basis.

\section{a. Slug Handilng and Charging}

While each component in the arrangement is a proven piece of equipment, the proper co-functioning has not been demonstrated. Suitable mechanical tests are planned to verify design assumptions, particularly in regard to the ability of the bucket to dump clean and the chute angle to provide a jam-free passage.

\section{b. "In-Iine" Pumps}

For some time efforts have been extended to develop canned rotor pumps for general process use. The cost advantages resulting from elimination of tanks and other auxiliaries are excellent incentive to move forward on this item. It is possible that a million dollars can be saved in this plant alone due to this development. Recent expereince in the hot semi-works shows good promise, with eventual success in sight. 


\section{c. Process Connectors}

While mechanically satisfactory,--the present type is highly dependent on high gasket performance. Further development of radiation resistant gaskets and mechanical arrangement are necessary to insure good couplings, particularly below static liquid level. The proposed deslgn, recognizing this limitation, utilizes remote flanges for the latter service.

Use of large remote flanges for pipes sizes from 8" upward has always been minimized due to alignment and gasket problems. The proposed plant requires many more of this type in both gas and Iiquid service. Furthur development of several large size remote connectors such as shown on SK-7-600 is essential for realization of objectives, although conventional flanges could be used if time were short.

d. Flexible Jumpers

In order to relax tolerances in vessel fabrication, intensive development of flexible jumpers is required. At the present time a low radiation ( $10 \mathrm{RAD}$ ) design is practical. Realization of reduced plant cost and contact maintenance, depend on general acceptance of this concept. Tests should be planned on this basis. As in connector design the problem lies partly in concept and partly in materials.

e. In-Line Samplers and Radiation Instrumentation

The proposed design places high dependence on satisfactory development of in-line instrumentation. The high cost of laboratory operation and construction as evidenced in the cost report is adequate incentive for vigorous effort in this field. Should this design revert to completely manual sampler operation, more tanks and bullding space in addition to the laboratory will be required.

f. Column Concatenation and Multiple Operation

The recent revisions to the Purex HA column point out the desirability of extending column size beyond the structural limitations of the shielding envelope. Aside from the use of different contactors, the best route remaining is concatenation. Other sites have successfully demonstrated this on small diameter, but final acceptance will be contingent on further demonstration using large diameter prototype units.

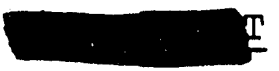


In the same category is the use of column packages and multiple usage of pulse generators. The proposed plant has only four. The 1A - IBX - and IC group of columns is pulsed from a single unit, as are the $2 D=2 E$ group. Further demonstration of the practicability of this arrangement await full scale tests and auxiliary development of a venting system which will continuously bleed vapors without excessive recycle of process solutions.

\section{g. Pulse Generators}

In support of column integration and concatenation, larger and more reliable pulsers become an essential development item. Packings require continuous evaluation, and as in the case of connectors, new materials and ideas should be tested. Hydraulic pulsers show promise of cost and size reduction without sacrifice of flexibility.

h. Coalescers

The problem of organic carry over in process streams is receiving attention at this time. Preliminary data indicate that a satisfactory unit is close to attainment. Continuing work on this item is both essential and valuable to the success of the proposed plant.

\section{ACKNOWLEDGEMEENTS}

The project cost estimates were prepared by the Estimating and Unit Costs Unit of the Project Section. Design schedules were supplied by the Design Planning Unit of the Design section. The procurement and construction schedules were developed with the assistance of the Project Section. Operating costs were developed with the assistance of the Manufacturing Department.
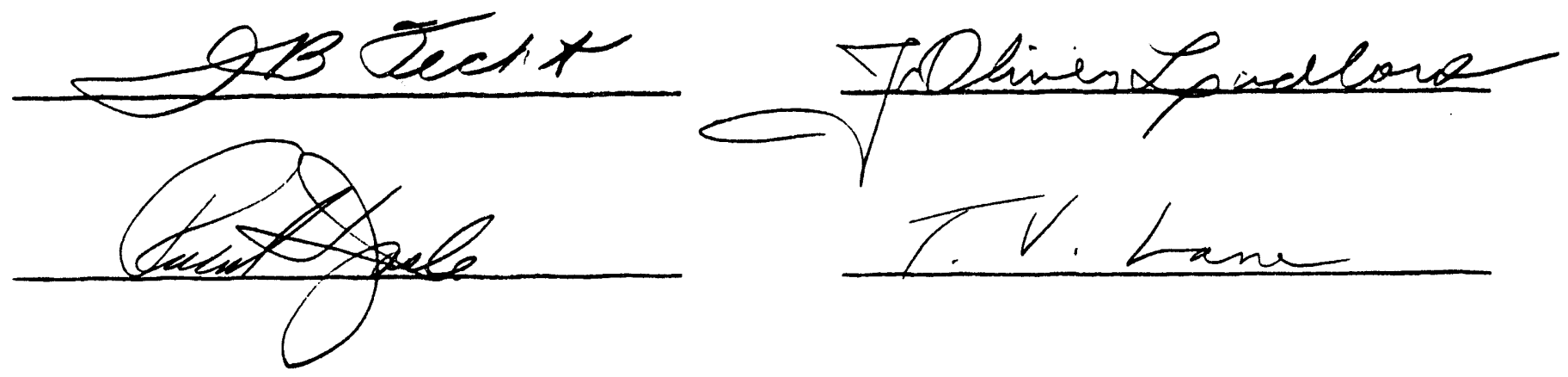

Separations Design \& Development

Design Section ENGINEERING DEPARTMENT 
VI. BIFLIOGRAPHY

(1) CF-55-2-117, "Continuous Normal Uranium Dissolution," FL Culler, February 17, -1955 .

(2) CF-55-3-190, "Status Report, Chemical Technical Division, Unit Operations Section," WK Eister, March, 1955; (Verbal information AM Platt, Chemical Development Sub-Section.)

(3) HW-30838, "Application of the Mercury Catalyzed Aluminum Technique

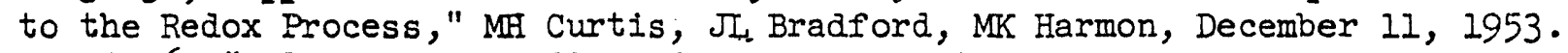

(4) HW-32316, "Pilot-Plant Studies of Mercury - Catalyzed Dissolving of Aluminum Jacket Fuel Elements," J Bradford, KI Adler, July I, 1954.

(5) IW-32823, "Proposed Alternate Dissolving Flowsheets for Redox Plant," MH Curtis, MK Harmon, August 13, 1954.

(6) HW-33297, "The Progress Report Chemical Development Unit--September, 1954," FW Woodfield, September 30, 1954.

$\rightarrow$ 7) HW-37319, "Future Separations Capacity," AB Greninger, July 1, 1955.

(8) HW-37998, "Redox Dissolver Facility Study," JB Fecht, RT Jaske, BL Lex, and Jo Ludlow, July 15, 1955.

(9) Ietter, "New Separations Plant," JB Fecht from GF Gabel, Estimating and Unit cost Unit, September 29, 1955.

(10) HW-21103, "Retention of Iodine in Process Solutions by Mercuric Salts," CH Holm, June 15, 1951. 


\section{APPENDICES}

\section{A. Notes for Estimating Purposes}

\section{202 Building}

a. Strocture \& Auxiliaries

The main processing building will be of reinforced concrete construction as shown on drawings H-2-1965 and H-2-1967. The building will contain three parallel rows of process equipment divided into two "hot" lines and one "cool" line. The latter consisting of the second uranium and plutonium cycles will be arranged for possible contact maintenance. A mechanical charging system and a slug storage system similar to the 100 areas will be used for fuel charging. See drawing H-2-1947. A single track railroad tunnel and a crane maintenance platform will be provided; the equipment being similar to Purex. A regulated shop and decontamination facility, also similar to Purex will be provided.

The PR load out facility will be located adjacent to the regulated shop and contact maintained line. It is anticipated that some simplification in PR handling equipment can be developed. A $6 \times 6$ foot elevator will serve the PR and regulated shop facilities.

The service and office areas will be of transite and steel construction. Floors will be poured concrete and the interior partitions Hauserman. The service area will be of multiple story construction with shops in the basement, control room and change room overhead, topped with lunch room and offices on the third level.

b. Process Equipment

The information below supp.lements flow sketch drawings SK-2-19111912-1913-1914-1919.

1. Process Cell Equipment

Equipment will be of two classes of construction. The "hot lines" comprising dissolving-waste-and first decontamination cycle, will be Class I construction using standard 200 Area definition. The second uranium and plutonium cycles will have standard shop tolerances and use flexible jumpers. In general, 304L stainless steel will be used with 308I rod. Weld craters will not be removed. 


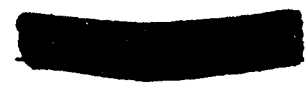

HW -38881

Page 42

a. Vessels

1. Dissolver - One Class I vessel per SK-2-5926.

2. Silver Reactors - These vessels to be of new design consisting of two sections 4'-6" diameter $x \quad 8$ feet each capped by a heater of Purex size. Total height 20 feet.

3. Acid Absorber - This tower will consist of two concatenated units in a single package. SK2-1918 shows one of these.

4. Gas Cooler - The dissolver off-gas cooler will consist of a vertical tube unit similar in appearance to the Purex tower. See SK-2-192l.

5. Tanks

a. 5000 gallon - 8 required - standard type for remote maintenance. Out of tolerance tanks to be used in "cool" row for potential contact maintenance.

b. 2500 gallon - 2 required - construction as above but with reduced capacity.

c. $2 A F$ tank - 1 required - construction as Purex, size dictated by location of 2 agitators and 1 pump.

6. Pulse Columns - The columns will be similar to Purex in basic construction but will be grouped into packages for reduction of connectors and inter-column flanged joints.

Package \#1

Packed Ht.

Diameter

Column IAX

IAIS

$12^{\prime}$ scrub - 12' extract 20"

IAS

$15^{\prime}$

$20^{\prime \prime}$

$20 "$

Package \#2

$\begin{array}{llr}\text { IBX } & 18^{\prime} & 20^{\prime \prime} \\ \text { IBS } & 12^{\prime} & 8^{\prime \prime} \\ \text { IC } & 15^{\prime} & 24^{\prime \prime}\end{array}$


Package \#3

$\begin{array}{lll}\text { 2DX } & 12 ' \text { scrub }-12^{\prime} \text { extract } & 20^{\prime \prime} \\ \text { 2DIS } & 15^{\prime} & 20^{\prime \prime} \\ \text { 2DS } & 15^{\prime} & 20^{\prime \prime}\end{array}$

Package \#4

$2 E$

$15^{\prime}$

$24 "$

Package \#5

$\begin{array}{lll}2 A & 25^{\prime} & 7^{\prime \prime} \\ 2 B & 18^{\prime} & 7^{\prime \prime}\end{array}$

Add I foot to heights for feed tee, and 2 feet for disengaging sections. In estimating, allowance for large 8" to 12 " pairs of connecting piping between columns should be considered.

7. Liquid Coolers - Four liquid coolers consisting of shell and tube bundle, about 3 " diameter by 9 feet long will be used. Remote 2 "flanged connectors will be used for process streams and 4" nozzles for water connections. See drawing SK-2-1928.

8. Concentrators - Three concentrating units will be made up of standard towers, boilers, and condensers. Boiler to be as SK-2-1926, condenser as SK-2-1927 and tower as SK-2-1930.
a. ICU Conc.
1 tower -4 boiler sections - 1 condenser
b. Waste Conc.
1 tower -2 boiler sections
c. Acid Tower
1 tower -2 boiler sections - 1 condenser

9. Filters - 2 required - The filters consist of fibrous glass packing exactly as Purex \#FA-1. York mesh will be added as a deentraining section.

b. Pumps

Pumps will be divided into two types depending on "in line" or tank service. Tank pumps will be standard as Purex. "In line" pumps will be a new enclosed type similar to canned rotor pumps. 
1. In Line Pumps - 10 required - Each having remote flanged inlet and outlet, power connections, microphone and temperature connections. 1 1/2 HP $75^{\prime}$ head.

2. Standard Tank Pumps

$$
\begin{array}{lrlll}
6 \text { required } & 25 \mathrm{GPM}-1 \mathrm{l} / 2 \mathrm{HP} & 75 \\
1 \text { required } & 25 \mathrm{GPM}-11 / 2 \mathrm{HP} & 75 & \text { Head } \\
3 \text { required } & 200 \mathrm{GPM}-71 / 2 \mathrm{HP} & 75 & \text { (Short) }
\end{array}
$$

c. Agitators

Standard type agitators will be required as follows:
6 required
$25 \mathrm{HP}$
$15 \mathrm{HP}$
2 HP
I required
$15 \mathrm{HP}$

\author{
Std.Tank (5000 Gal.) \\ Std. Tank (5000 Gal.) \\ Short Tank (2AF) \\ Small Tank (2500 Gal.)
}
2 required

d.. Centrifuges

Two centrifuges will be required. Both will be identical to Purex liquid, solid units with addition of extra takeoff connections to facilitate arrangement.

e. Pulse Generators

Four pulse generators will be used. These units will be similar in concept to Purex, but because greater pulse energy is required, two will be substantially larger. A factor of ten in rating would be about correct. One each small size will be used for the $2 A-2 B$ package and the IBS column.

f. Instrumentation and Electrical

Instrumentation and electrical equipment would be typical of that provided for Purex plants. A single graphic panel would be located in the control room.

8. Piping

Included below are some comments on piping which may assist in the cost estimate. Since the actual runs have not been measured, at best these are educated guesses.

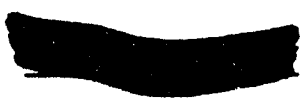


1. Through concrete--about $1 / 2$ of Purex based on the reduction in process steps, smaller pipe sizes due to shorter runs, and generally more economical arrangement. All lines to be stainless other than electrical.

2. Cell Jumpers

Rigid and flexible jumpers will be used depending on the radiation intensity to be expected in the cells. Flexible jumpers would be used in radiation fields less than 10 Rad per hour.

Rigid type jumpers will be fabricated to high tolerance as Purex.

Flexible jumpers will be fabricated using modified remote female connectors and a flexible hose covered with stainless braid. Hose material will be Teflon for process jumpers and rubber for instrument, electrical, and steam lines.

a. Rigid Type*

Process-Steam-Water-Air

$\begin{array}{lr}2 " & 150 \\ 4 " & 70 \\ \text { Sampler } & 15 \\ \text { Inst. } & 125 \\ \text { Electrical Power } & 25 \\ & 385\end{array}$

b. Flexible Type*

Process-Steam-Water-Air

$\begin{array}{lr}2 " & 40 \\ 4 " & 20 \\ \text { Sampler } & 10 \\ \text { Inst. } & 30 \\ \text { Electrical Power } & \frac{15}{115}\end{array}$

3. Remote Flange Type

25-2" remote flanged liquid lines will be used for vessel and pump connections below the liquid level.

*Shown as 2" and 4" - Actually 1/2, 1 and 3 will be used also. 


\section{UEDLASSIFED}

HW -38881

Page 46

Each flange will be of 3 bolt style about 12 " in diameter with one locating dowel.

15-large remote liquid and gas vessel connections ranging from 6" to 12 " will be provided. Connectors will be either remote flange, or a new connector style adaptable to any size pipe.

4. Hot Pipe Trench

Hot pipe trench piping will be installed similar to that in Purex. Stainless steel will be used throughout.

\section{Pipe Size}

I"
$2 "$
$3 "$
$4 "$
$6 "$
Length Incl. Spares

6500

5500

3500

2200

500

h. Jets

Jets will be provided for usual functions of vessel venting, liquid transfer and sump drainage.

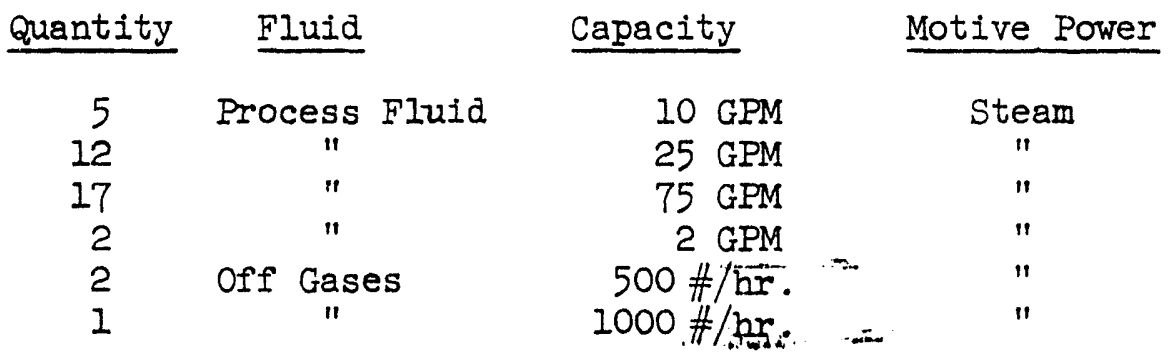

\section{Organic Treatment Equipment}

a. Tanks

Four @ 10' x 10' - 5000 gallon - To have standard flanged pipe connections but remote flange for treatment units.

b. Decanters

Two @ 4'x 5' - 500 gallon - Same construction as Purex.

\section{c. Pumps}

Two @ 28 GPM - 2 HP - 75 feet head. 
d. Jets

Air operated - two 50 GPM and four 75 GPM.

e. Agitators

Four required - $25 \mathrm{HP}$ - includes two of the special mixers shown on SK-2-1920.

3. Other Non-Cell Equipment

a. Pulse Generator Variable Speed Controllers

Control Systems similar to those used for the Purex pulsers will be used.

b. Chemical Preparation

A total of 12 tanks and a demineralized water unit plus auxiliary pumps, agitators, instruments, electrical, and piping will be required.

The following tanks are required:

Quantity
2
4
3
2
1

\begin{tabular}{cr} 
Volume, gals. & Dia. \& Hei \\
\hline 3000 gal. & $6 \times 8$ \\
3000 gal. & $6 \times 8$ \\
700 gal. & $5 \times 5$ \\
700 gal. & $5 \times 5$ \\
200 gal. & $2 \times 4$
\end{tabular}

Material
304L Stainless
Carbon stl
304 L Stainless
Carbon stl
304 L Stainless

Cooling coils

The demineralized water unit which would be an ion exchange type and would have an instantaneous capacity of 50 gallons per minute. Caustic and acid tanks for regeneration would be included.

The following pumps will be required:

\begin{tabular}{|c|c|c|c|c|c|}
\hline Quantity & Type & GPM & Head & HP & Material \\
\hline 1 & Cent. & 100 & 75 & 8 & Stainless stl. \\
\hline 1 & Cent. & 100 & 75 & 8 & C. Steel \\
\hline 2 & Cent. & 10 & 100 & 1 & C. Steel \\
\hline 1 & Cent. & 10 & 100 & 1 & Stainless stl. \\
\hline 1 & Cent. & 20 & 1850 & 35 & Stainless stl. \\
\hline
\end{tabular}


The following agitators will be required:

Number

\begin{tabular}{c} 
Tank Size \\
\hline 3000 \\
3000 \\
700 \\
700 \\
200
\end{tabular}

$\begin{aligned} \text { HP } & \text { Material } \\ 5 & \text { Stainless Stl. } \\ 5 & \text { Carbon Stl. } \\ 1 & \text { Stainless Stl. } \\ 2 & \text { Carbon Stl. } \\ 1 / 2 & \text { Stainless Stl. }\end{aligned}$

Feed Filters as follows:

Each chemical add stream will have one filter similar to Purex filter F-102.

c. PR Equipment

Product removal cans and handling equipment will follow the same general pattern as Purex but efforts at simplification and cost reduction will be made.

d. PR Cans and Carriers

These to be the same as Purex for interchangability. A total of 50 will be supplied.

e. Samplers

A total of 26 samplers will be required.

Type A (1)

Type B (2)

15

Type C (3)

(1) Redesigned Gilmont Sampler SK-2-1970

(2) Purex Bayonet Sampler

(3) Purex Gas Sampler

\section{f. Instrumentation}

Instrumentation would be similar to that for Purex. Plastic tubing such as Dekoran can be assumed if savings are evident.

Central control will be used. The graphic panel will be about 100 feet long. 
HW -38881

Page 49

\section{g. Piping}

Piping for process utilities - steam - water - air will be installed per HAPO standard practice. Line sizes and lengths would be approximately as listed.

Fluid

High Press. Stm.

Low Press. Stm.

Compressed Air

Cooling Water

Sanitary Water
Line Size

8"

6"

4"

3"

$10^{\prime \prime}$

8"

6"

4"

$2^{\prime \prime}$

$11 / 2^{\prime \prime}$

I"

$10^{\prime \prime}$

8"

6"

$3^{\prime \prime}-2^{\prime \prime}-1$ "

$4 "$

2"
Length

500

1100

3500

2000

300

500

1000

1500

1500

1000

1000

500

600

1200

2400

1500

1000

Plastic piping will be used for transfer of corrosive chemicals with the exception of wash solutions.

Material

Line Size

Length

Psig

Polyvinyl Chloride

$$
\begin{array}{r}
2 " \\
\text { 1" } \\
1 / 2 " \\
2 " \\
2 "
\end{array}
$$

Polyethyene

Stainless Steel

Carbon Stl.

1500

1500

500

1500

800

75
75
75
75
75

\section{c. Miscellaneous}

\section{Process Crane}

An electrically-driven bridge crane similar to Purex main crane will be used in the process area. The crane will have a span of 78 feet and a total lift of 56 feet. It 
HW -38881

Page 50

will have a 50 ton main holst, a 10 ton secondary hoist, and $1 / 2$ and $I$ ton auxiliary holsts on each of the two box girders. Operation from a cantilevered, shielded cab wlll be accomplished by optical viewing.

2. Dissolver Charger Monorail

The dissolver tower charger cannot be reached by the main crane hooks and requires a monorail to move sections to a location where the main crane can reach. This equipment would be remotely operated from the crane cab.

3. Ventilation System

This system will consist of a divided type process air handling system similar to $100-\mathrm{K}$ but nominally rated $140,000 \mathrm{CFM}$ with both units running full. Normally one unit will be throttled to $20,000 \mathrm{CFM}$. In addition, a service side system of 60,000 CFM will be provided. These units will consist of pre-heaters filters, alr washers, and re-heaters as conventionally considered. A 6,000 CFM recirculated refrigerated air conditioning system will serve the control room, lobby, dispatchers office, and supervisors office. Heat for air handling equipment will be recovered by means of a surface condenser from the waste cooling water stream. In addition, a by-pass heat exchanger fed by steam will supply adequate hot water to the air handling apparatus when the process is shut down. This equipment will be located in a shielded basement area underneath the service blower room.

4. Compressed Air System

One 200 SCFM water sealed Nash compressor for instruments (80-85 psi) and two 500 SCFM, 125 ps1, units with $4 \times 12$ receivers for the process system. The instrument air system will include recelver $(3 \times 8)$ air dryer, and back up connection to process air system.

5. Breathing Air System

To be 200 SCFM capacity, dried, filtered, and stored at 50 psi in a $4 \times 10$ recelver. Fifty outlets in strategic locations in sample gallery - process cells, crane maintenance line, regulated shop, - PR facility, hot shop, railroad tunnel, solvent recovery vault and contact maintained extraction line. 
HW -38881

Page 51

\section{Air Sampling System}

Essentlally as Purex. A central vacuum pump in sample gallery. About 40 sample points. Utilization factor $331 / 3 \%$.

7. HM Ionization Chambers

The standard treatment will be given. About 40 instruments will be required reading on 10 point recorders in dispatchers office.

8. Comunications System

A building communication system consisting of a 75 unit automatic local exchange will be provided. Twenty-five phones on the HAPO exchange will be required.

9. Protective Coatings

The following potentially contaminated zones will be painted w1th protective coating: process cells, hot shop, decontamination cell, regulated shop, PR room, sample galleries, pipe galleries.

10. Cell Wash Down

A cell spray system with nozzles at 15 foot centers will be provided on both sides of each process cell. Additional equipment sprays will be located about as in Purex.

\section{Organic Cell Fire Protection}

The organic cell will be provided with a fire detection system and automatic water fog spray nozzles.

\section{291 Area}

The 291 facility will be provided to handle 140,000 CFM of canyon and gallery exhaust air. This facility is located on the plot plan.

(a) Fibrous glass filter as Purex about $70^{\prime} \times 70^{\prime}$ consisting of a 2 bed fore filter each $35^{\prime} \times 50^{\prime}$ and an after filter $70^{\prime}$ $\times 20^{\prime}$.

(b) Concrete stack 200' tall with either free standing stainless or integral chemical brick liner. 
$\mathrm{HW}-38881$

Page 52

(c) Two Vinyl coated carbon steel exhaust fans each 70,000 CFM capacity at 11 " water with a $150 \mathrm{HP}$ motor. One of these to have a dual drive, consisting of a $150 \mathrm{HP}$ steam turbine and $150 \mathrm{BP}$ electric motor.

(d) One stack sampling facility as Purex.

(e) One glass filter sampling house as Purex.

3. 211 Chemical Storage Farm

Storage facilities for nitric acid, hydrocarbon diluent, TBP, and caustic, will be provided.

\begin{tabular}{|c|c|c|}
\hline Capacity & Service & Material \\
\hline $100,000 \mathrm{Gal}$. & $\mathrm{HNO}_{3}$ & 304L S. S. \\
\hline $100,000 \mathrm{Gal}$. & $\mathrm{HNO}_{3}$ & $304 \mathrm{~L}$ S. S. \\
\hline $50,000 \mathrm{Gal}$. & NAOH & Carbon Stl. \\
\hline $50,000 \mathrm{Gal}$. & Demin. Water & Aluminum \\
\hline $65,000 \mathrm{Gal}$. & TBP Diluent & Carbon stl. \\
\hline $30,000 \mathrm{Gal}$. & TBP & Carbon Stl. \\
\hline 1,000 Gal. & $\mathrm{H}_{2} \mathrm{SO}_{4} *$ & Carbon StI. \\
\hline 5,000 Gal. & TBP Mix Tank & Carbon StI. \\
\hline
\end{tabular}

The following pumps will supplement the 211 facility:

\begin{tabular}{|c|c|c|c|c|}
\hline Number & GPM & Head & $\underline{\mathrm{HP}}$ & Material \\
\hline 2 & 80 & 100 & $71 / 2$ & Stainless Stl. \\
\hline 2 & 20 & 100 & 2 & Stainless stl. \\
\hline 1 & 80 & 50 & 3 & Carbon Stl. \\
\hline 2 & 10 & 50 & $1 / 2$ & Carbon Stl. \\
\hline 2 & 80 & 100 & $71 / 2$ & Carbon StI. \\
\hline 2 & 125 & 50 & $71 / 2$ & Carbon Stl. \\
\hline 1 & 50 & 100 & 10 & Carbon stl. \\
\hline 2 & 25 & 100 & 5 & Carbon StI. \\
\hline
\end{tabular}

Demineralize capacity to be $50 \mathrm{gal}$./min.

4. Recovered Uranium Storage

Recovered uranoum solution will be transferred to a process vault located outside the process building (see site plan). It will resemble the $W R$ vault at $U$ Plant, but will have three 20,000 gallon tanks for 10 hours running storage. Materials of construction, pumps, etc. will closely resemble the U Plant installation except in quantity which will be adjusted to the three tank basis.

* For laboratory 


\section{DEDLASAIFED}

HW -38881

Page 53

5. Waste Tank Farm

Waste flow from the facility is about 100,000 gallons per month which can be concentrated about 3:1 depending on exposure history. The farm should resemble purex in basic concept except as follows:

(a) Tanks to be capable of holding 2.5 gravity l1quid.

(b) Vapor handling system to consist of condenser--evaporator and barometric condenser. Drainage to be either recirculated or disposed to a swamp.

(c) Capacity of the farm should be about 6 million gallons.

(d) Direct buried, coated lines will be employed.

6. Miscellaneous Waste Facilities (*Details by C. R. Bergdahl)

Crib waste flows while undetermined will be about $1 / 2$ that of Purex. Cribs will be required for the following services:

$\begin{array}{lll}\text { Organic Waste } & \text { Intermittent } & 201 \times 20^{\prime} \\ \text { Lab \& Cell Drains } & \text { Intermittent } & 30 \times 30 \\ \text { Process Condensate } & \text { Continuous* } & 100 \mathrm{GPM} \\ \text { Steam Condensate } & \text { Continuous* } & 225 \mathrm{GPM} \\ \text { Diversion Box Drains } & \text { Intermittent } & 20 \times 20 \\ \text { Tank Farm Condensate } & \text { Emergency Basis } & 100 \mathrm{GPM} \\ 203 \text { Facility Sump } & \text { To Diversion Box Crib }\end{array}$

Cooling water (2500 GPM) will be disposed of by swamp through a 24 " V.C.P. line.

\section{General Area Fac1lities}

The general area facilities will be shown on the plot plant SK-2-1968 and SK-2-1969 and consist of:
(a) Roads and walks.
(b) Exclusion area fencing \& lighting
(c) Street lighting
(d) Railroads
(e) Exclusion area badge house (as 100-C)
(f) Sanitary waste disposal for 130 people/shift

* See Bergdahl for sizing 


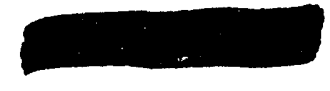

HW-38881

Page 54

(g) Hydrants and fire protection system

(h) Extension and rehabilitation of 200 Area burial grounds

8. Analytical and Control Laboratory

The Purex Analytical Control Laboratory can be used as a direct basis for this item. The unit will be located about 80 feet from the main building and connected with a service tunnel for handing samples and utilities. The structure is about $58 \times 144$ feet in size and is entirely self contained.

\section{Utilities Service}

The following utilities service is required. See the plot plan for line and equipment locations.

(a) Electrical demand $1875 \mathrm{KW}$ normal. Emergency Service $200 \mathrm{KW}$ (Diesel Generator)

(b) Raw Water 2500 GPM

(c) Filtered Water 500 GPM

(d) Sanitary Water -- High tank and system for 130 person normal requirement.

(e) Steam Supply -- 40,000 \#/hr. for process and 10 to 30,000 for ventilation depending on operation of heat recovery system. $50,000 \mathrm{\#} / \mathrm{hr}$. is a nominal quantity which could go to 70,000 if the vent heat recovery system was not functioning.

\section{Spare Equipment}

The following process equipment spares should be included in the estimate:

Unit

Dissolver

Gas Cooler

Iiquid Cooler

Absorption Tower (Double Unit)

off-Gas Filters

5000 Gallon Tanks Std. 2500 Gallon Tanks Std. 2AF Tank

\section{No. Installed Spares}

11

11

11

$1 \quad 1$

62

$\begin{array}{ll}2 & 1 \\ 1 & 1\end{array}$

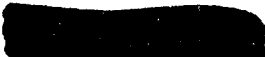




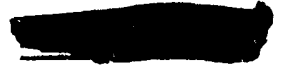

HW -38881

Page 55

Silver Reactor \& Heater

2

1

1A Tower Package

IB-IC Tower Package

2D Tower Package

2E Tower

$2 A-2 B$ Tower Package

Waste Concentrator Tower

Waste Concentrator Boilers

- 1

Acid Tower

Acid Boilers

Acid Tower Condensers

1

1

1

1

--

1

1

1

1

ICU Concentrator Tower

ICU Concentrator Bollers

ICU Concentrator Condenser

ICU Concentrator Cooler

1

2

1

$I L-I R$

1

2

1

$I L-I R$

15HP stã. Tenks

Agitators 25HP Std. Tanks

2HP Short Tanks

15HP SmalI Tank

$\frac{1}{4} \quad$ IL-IR

1

1

1

Pumps

$11 / 2 \mathrm{HP}$ Std. Tank

1 1/2 HP Short Tank

$11 / 2$ 파 "In Line"

7 1/2 HP Std. Tank

Condenser Vent Jet $1000 \# / \mathrm{hr}$.

Dissolver Vent Jet $500 \# / \mathrm{hr}$.

Vessel Vent Jet $500 \# / \mathrm{hr}$.

Liquid Trans. Jets 2 GPM

Liquid Trans. Jets 10 GPM

Liquid Trans. Jets 25 GPM

Liquid Trans. Jets 75 GPM

$\frac{3}{6}$

2

2

6

1

10

3

1

1

1

2

Pulse Generators Large Small

Hot Rotameters

40

Hot Control Valves

85

Automatic Controllers

Jumpers Rigid 


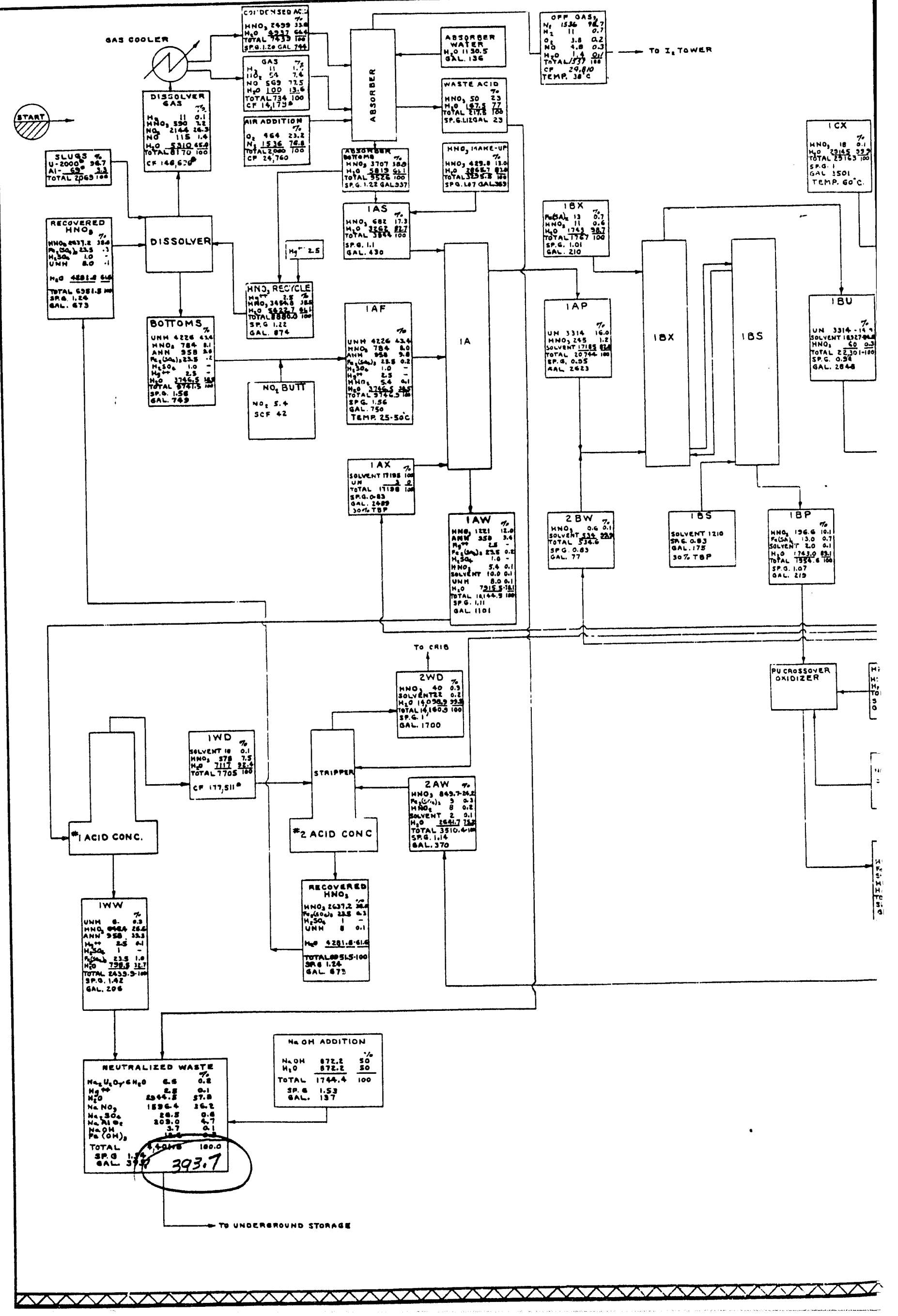



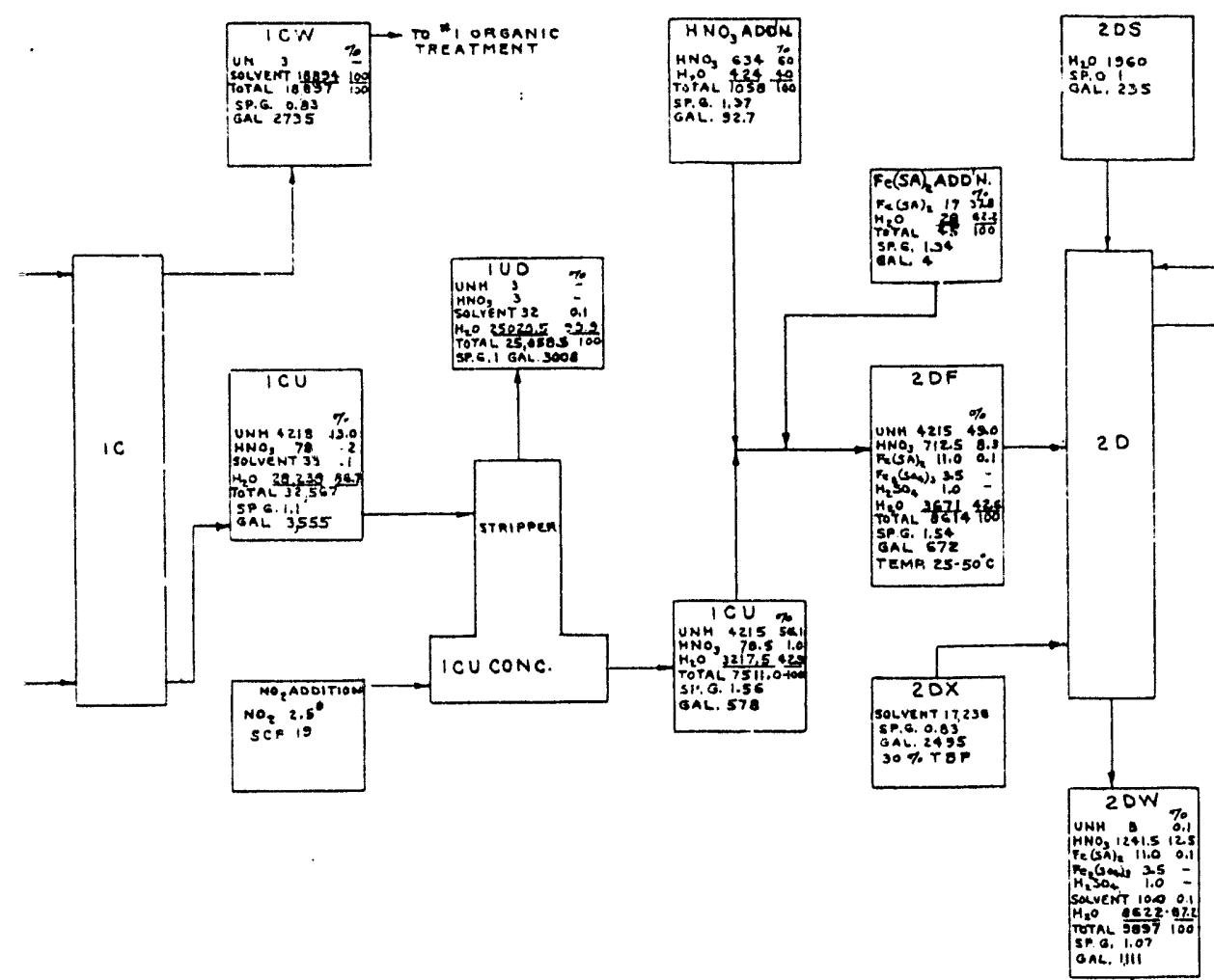

DEEASSIIITE
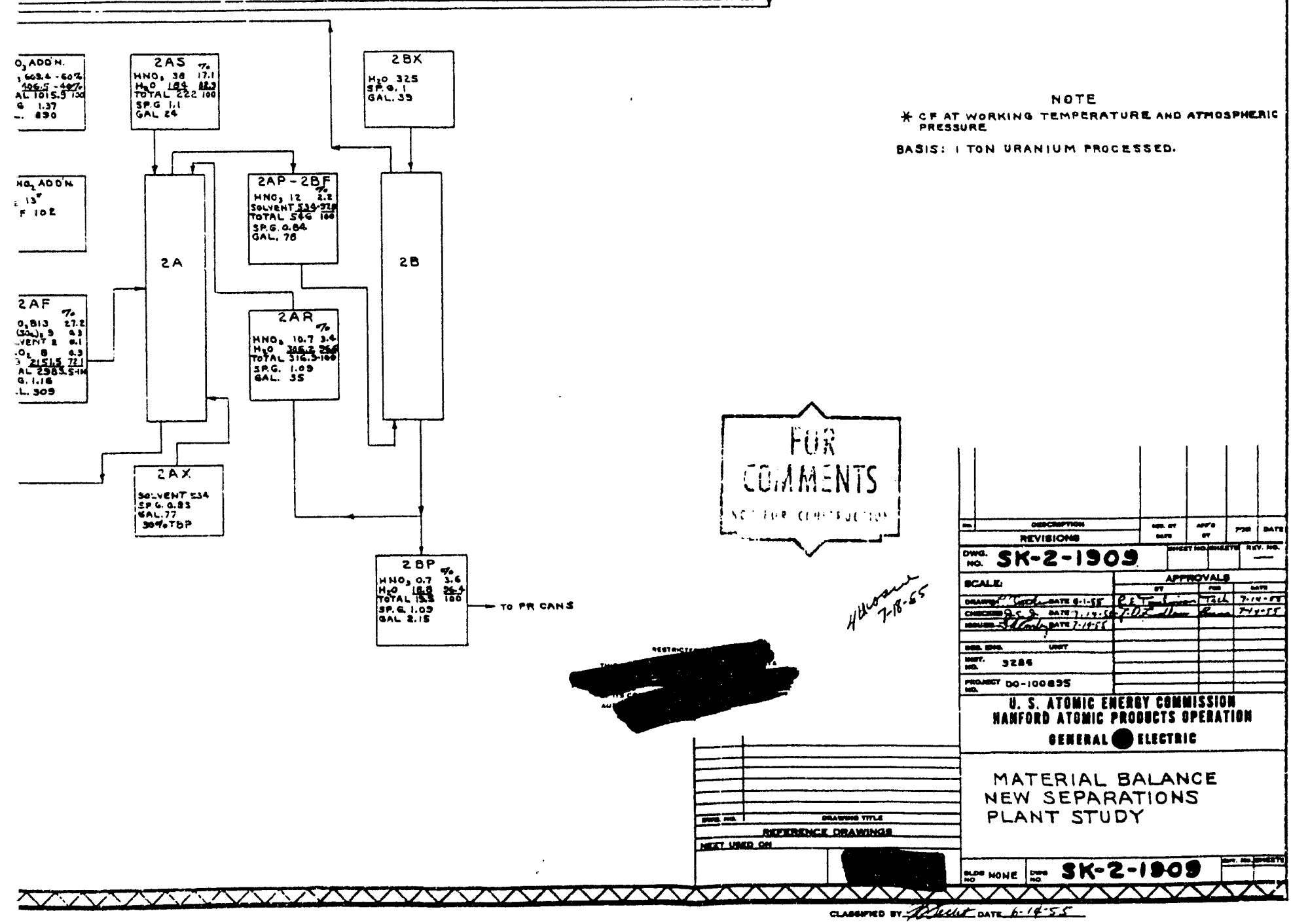

* crat working temperature amo atmosphenic

BASIS: I TON URANIUM PROCESSED.

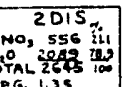

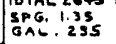

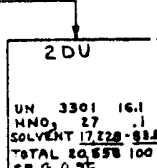
TPS 20.95

$2 \varepsilon$

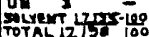
saí. 20.48 $30 \%$ TeP
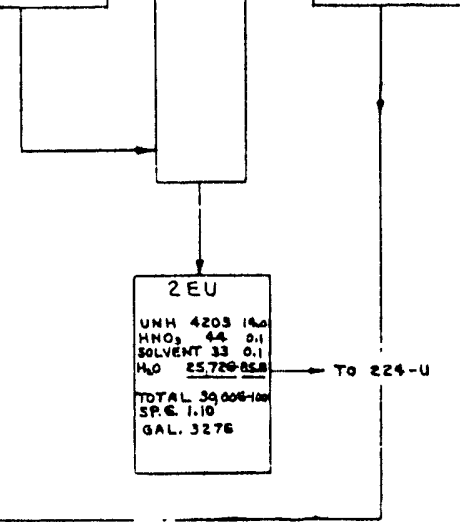


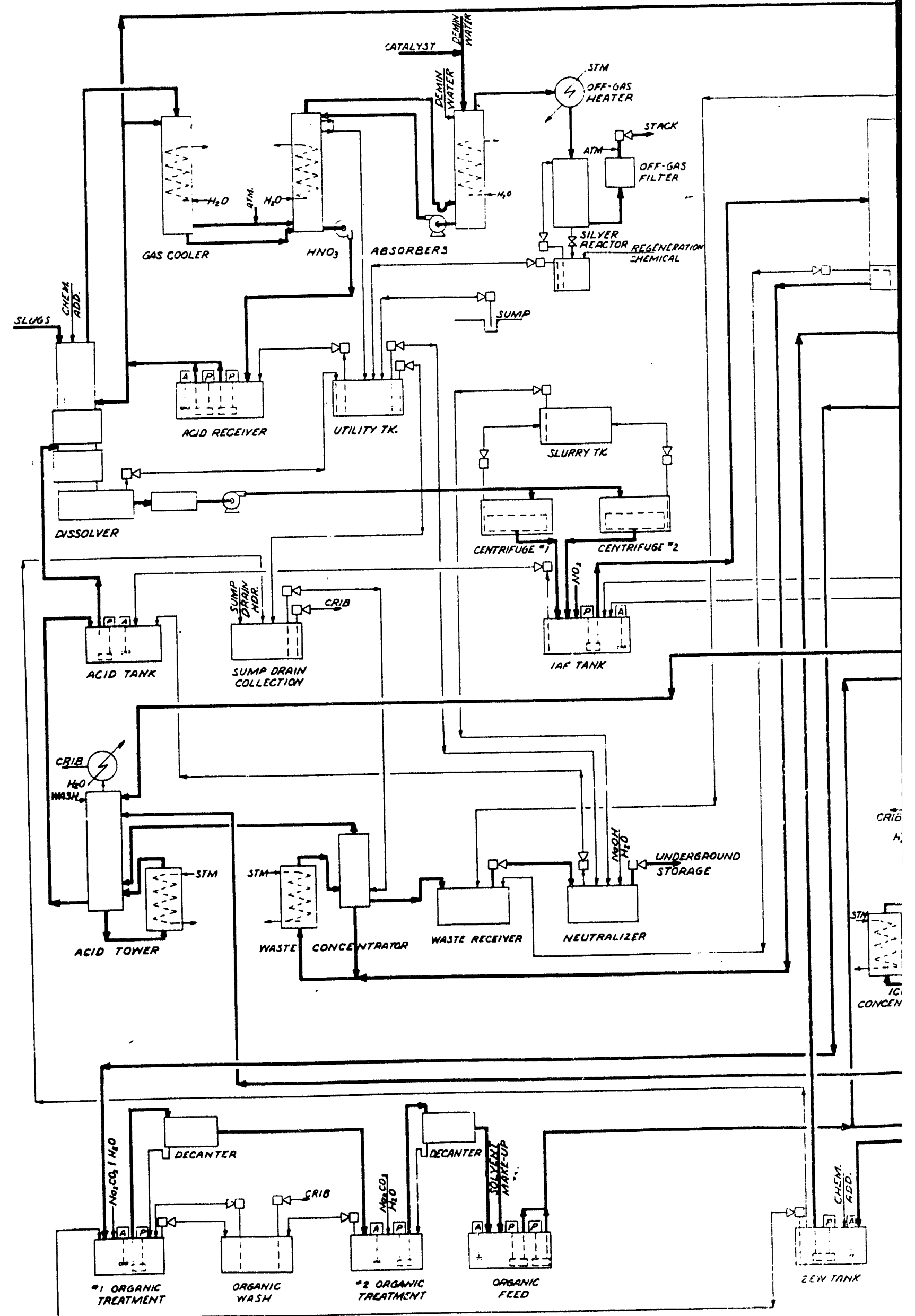




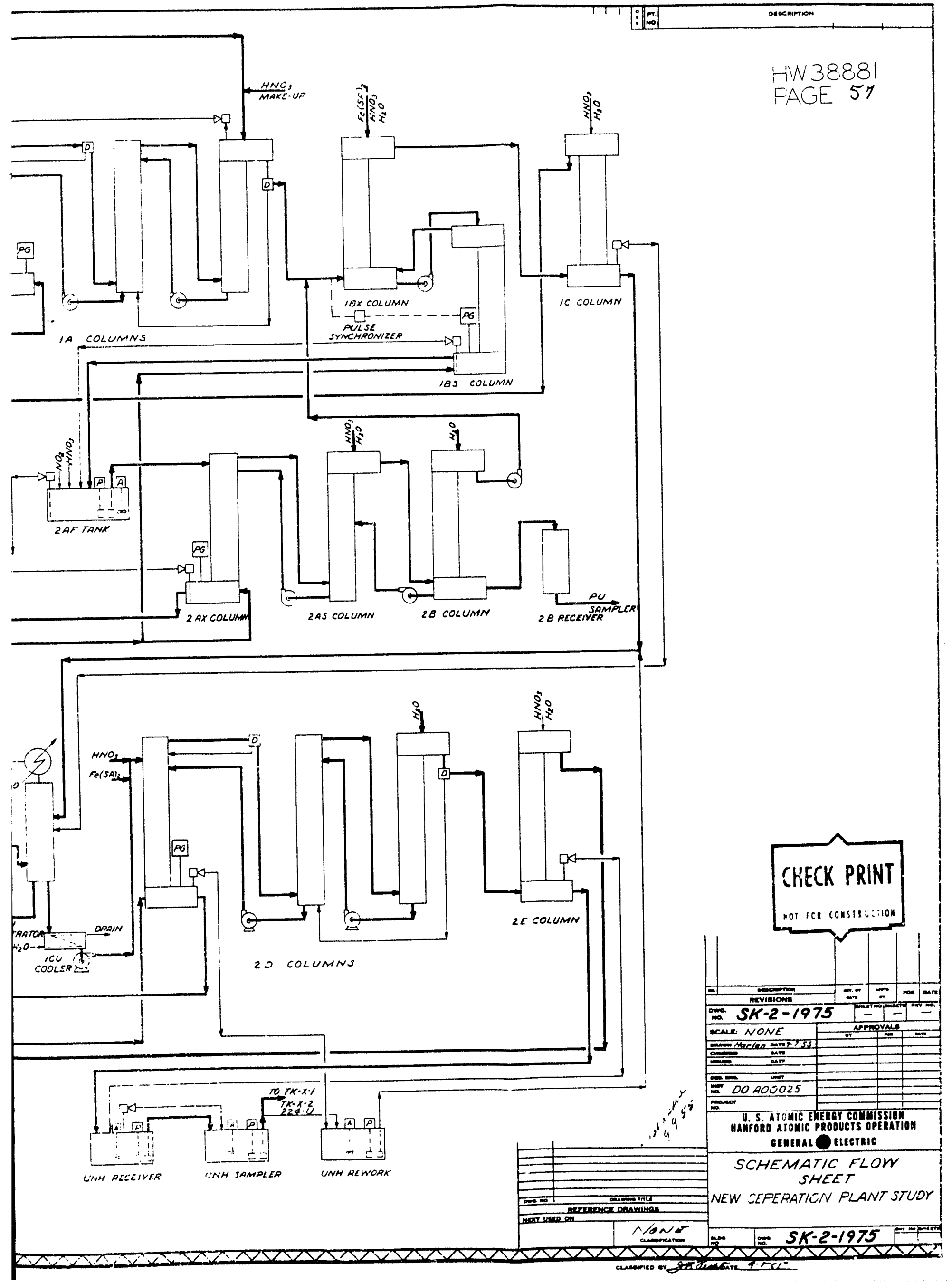




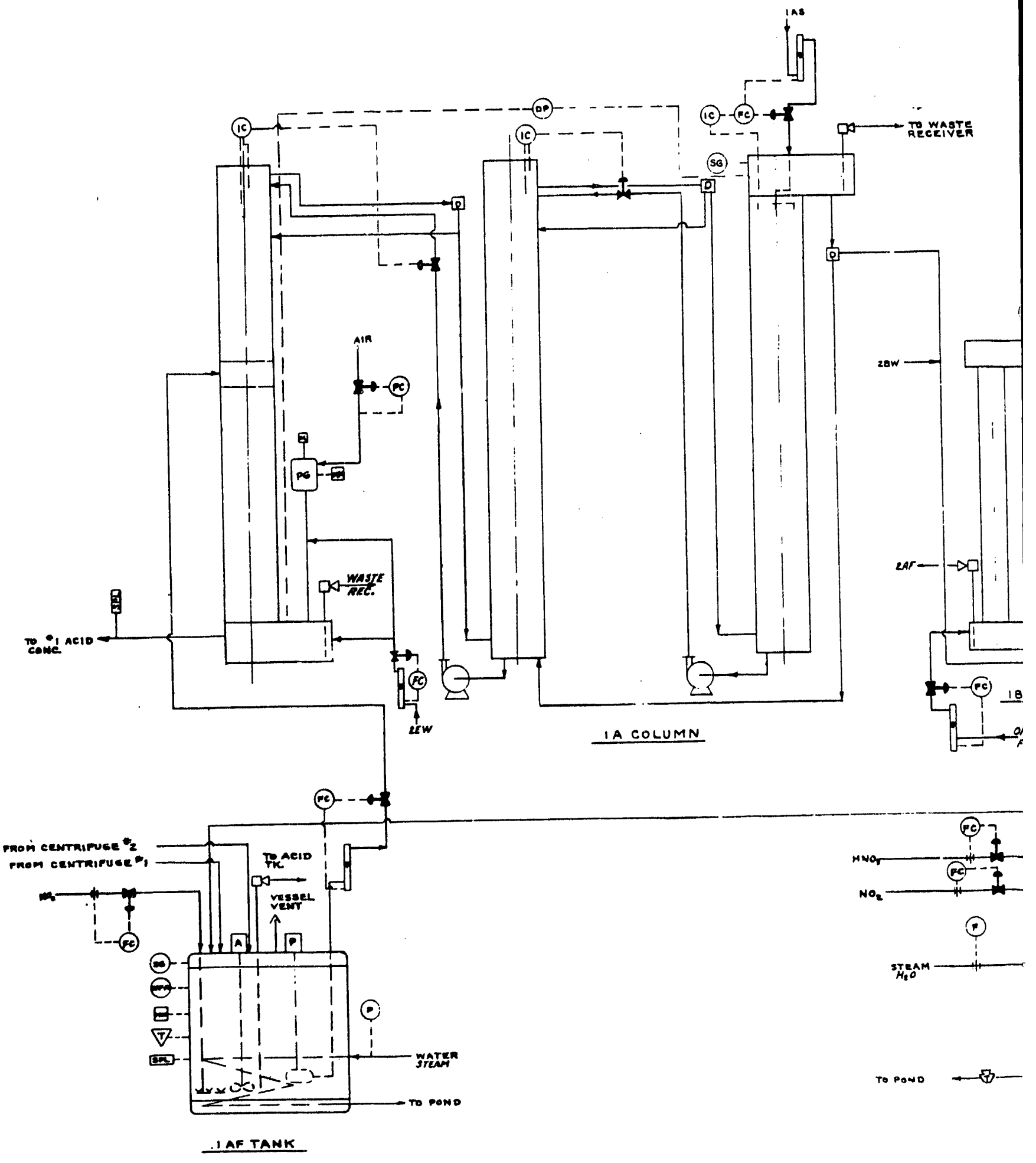



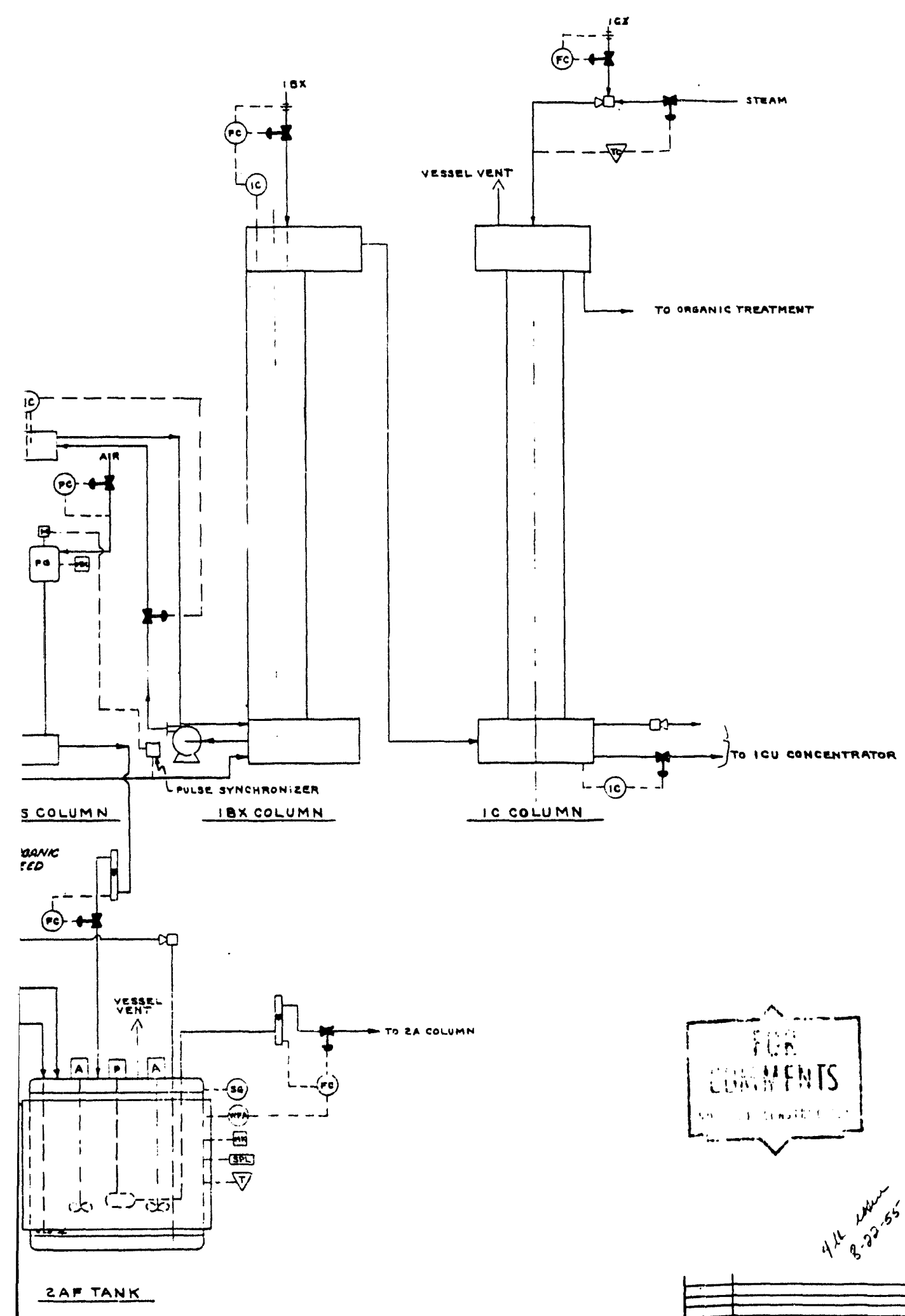

NOTE

D- deEnTrainment Dox IC COLUMN
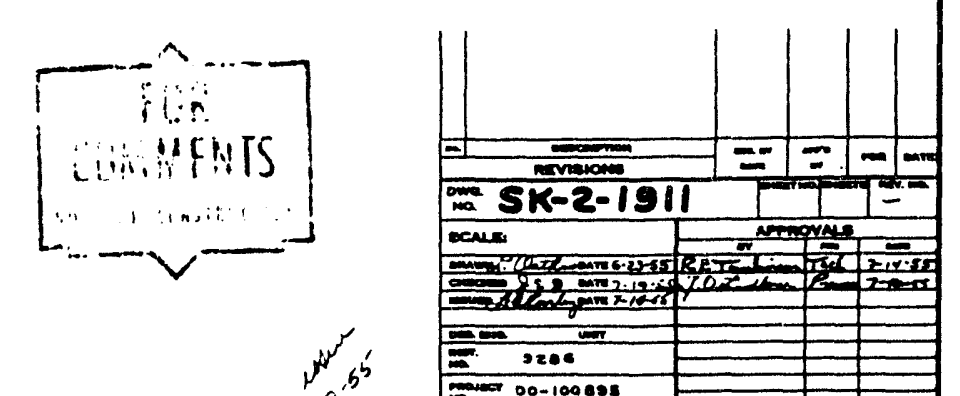

$+b^{2}$

(1) $)^{2}, \partial^{2}$

$00-100998$

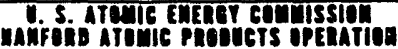
imenas meternic

PARTITION CYCLE PROCESS FLOW SKETCH NEW SEPARATIONS

NEW SEPARATIOY 


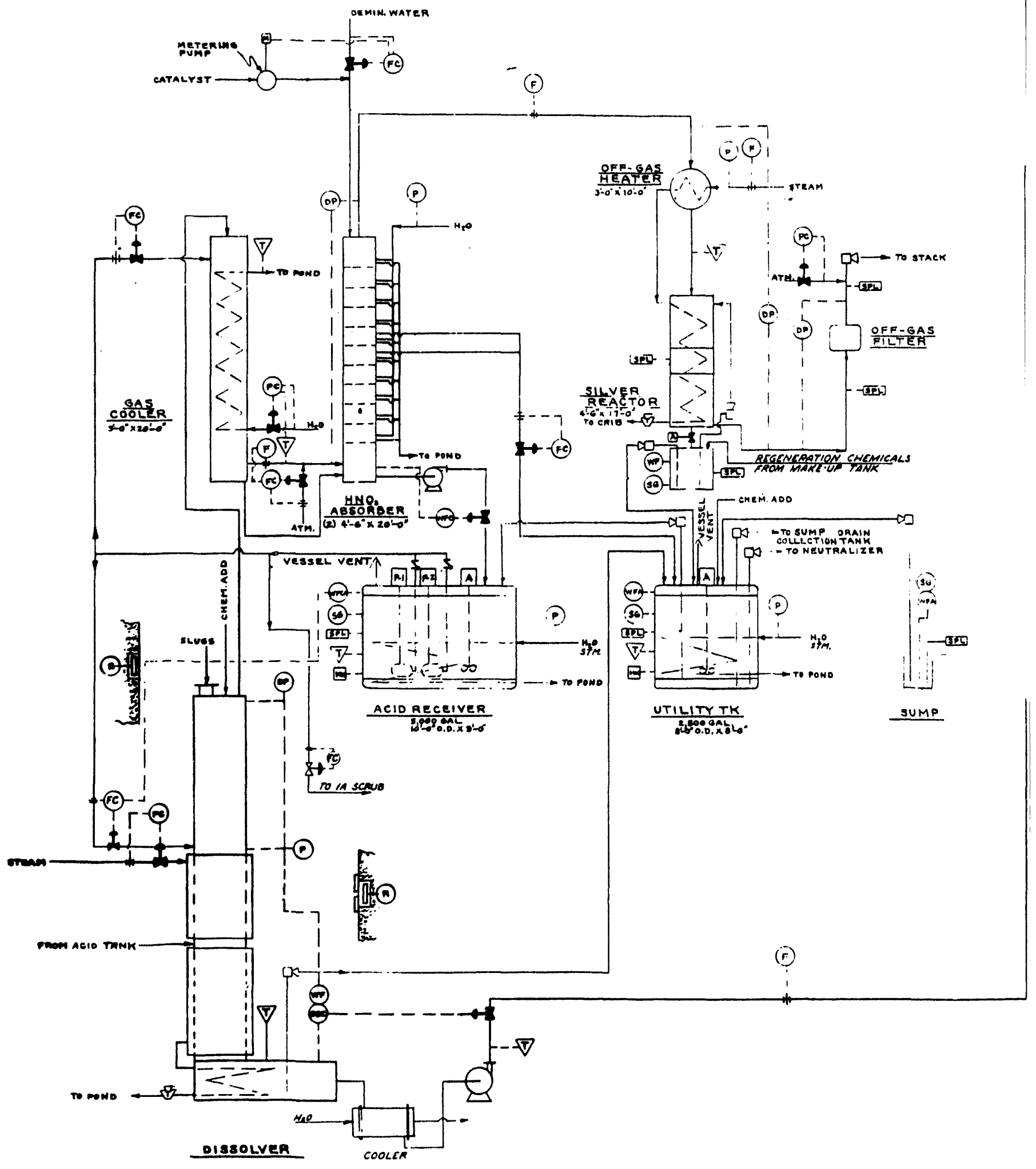


HW 38881

PAGE 59

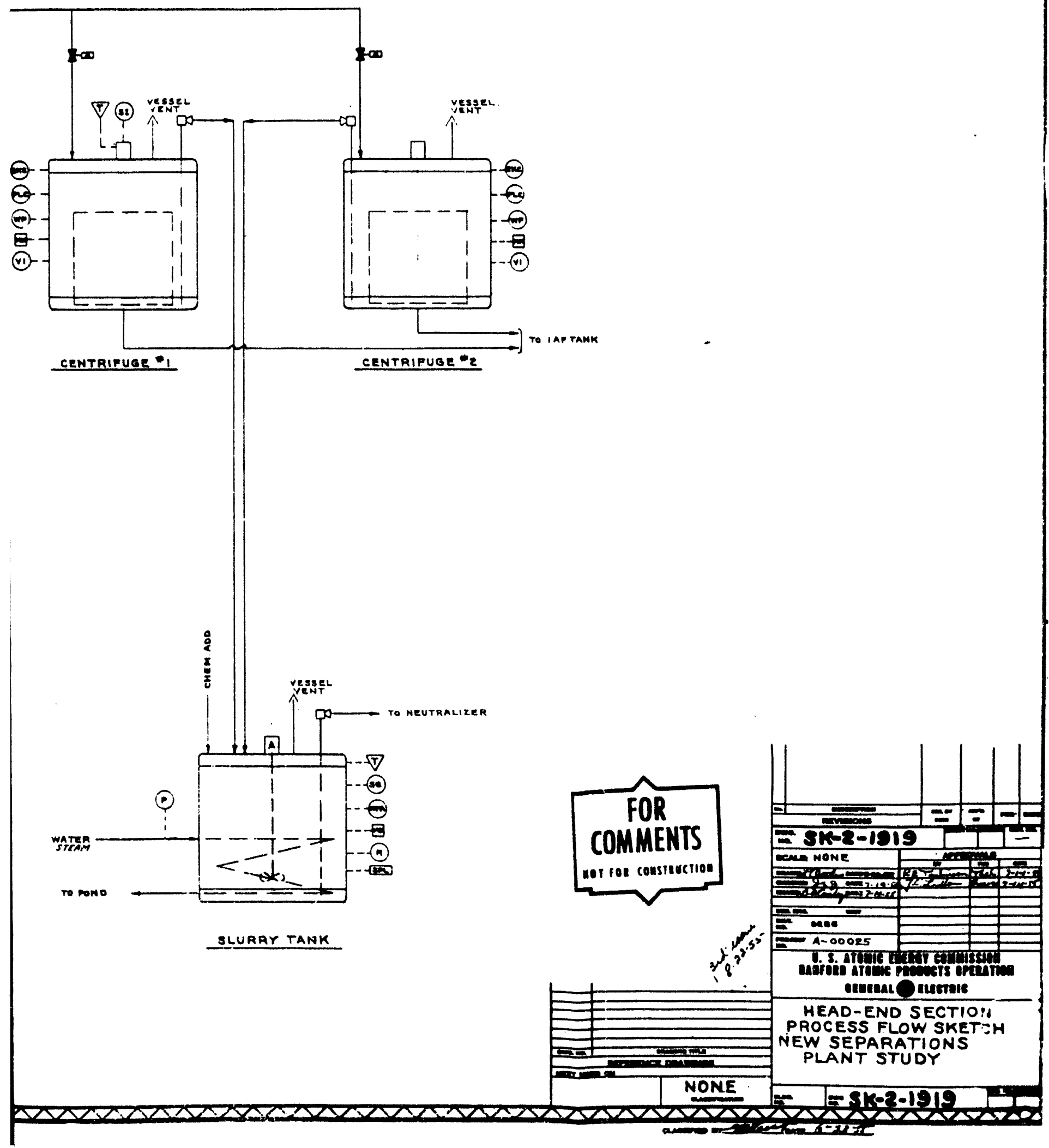




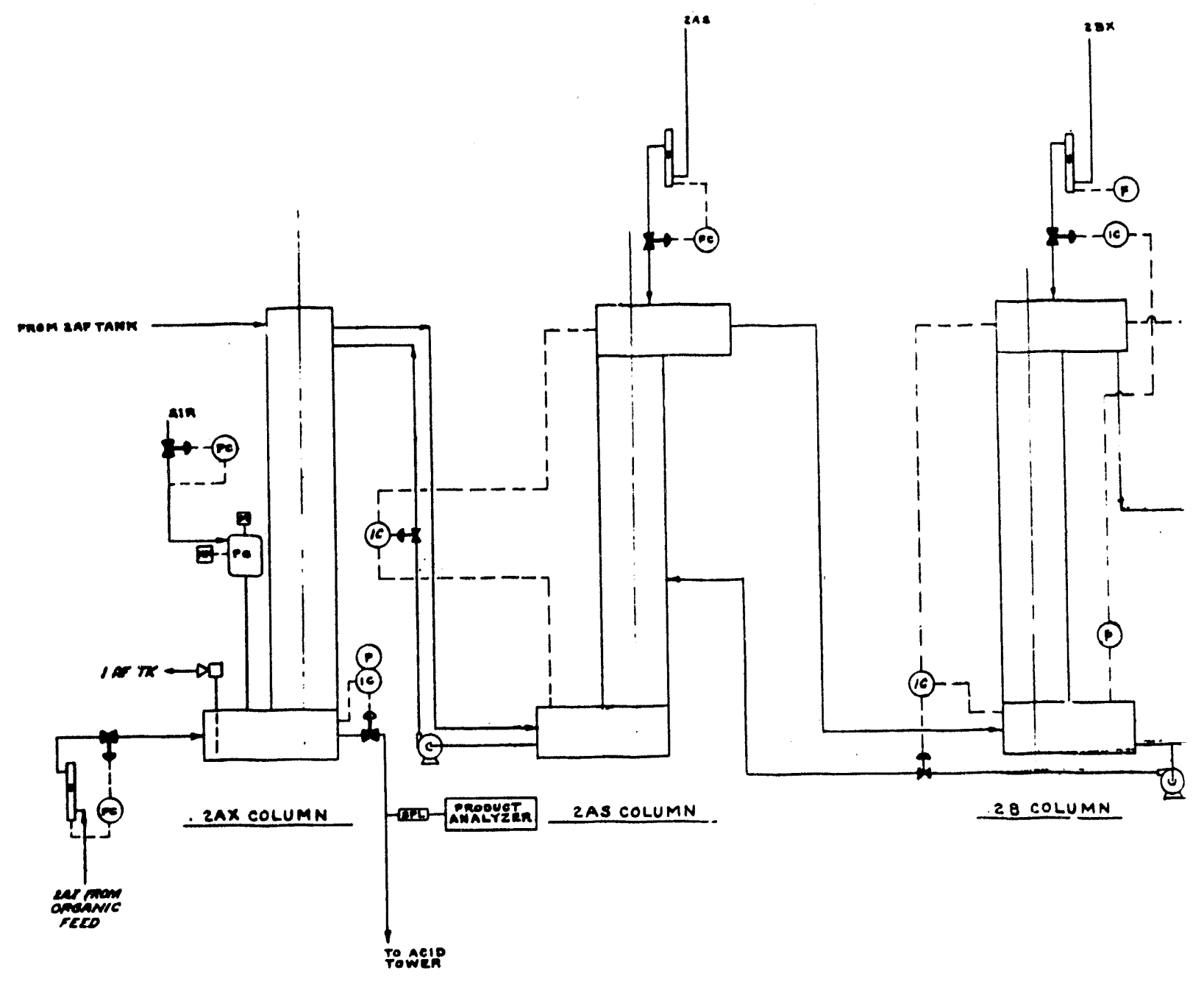


HW38881

PAGE 60
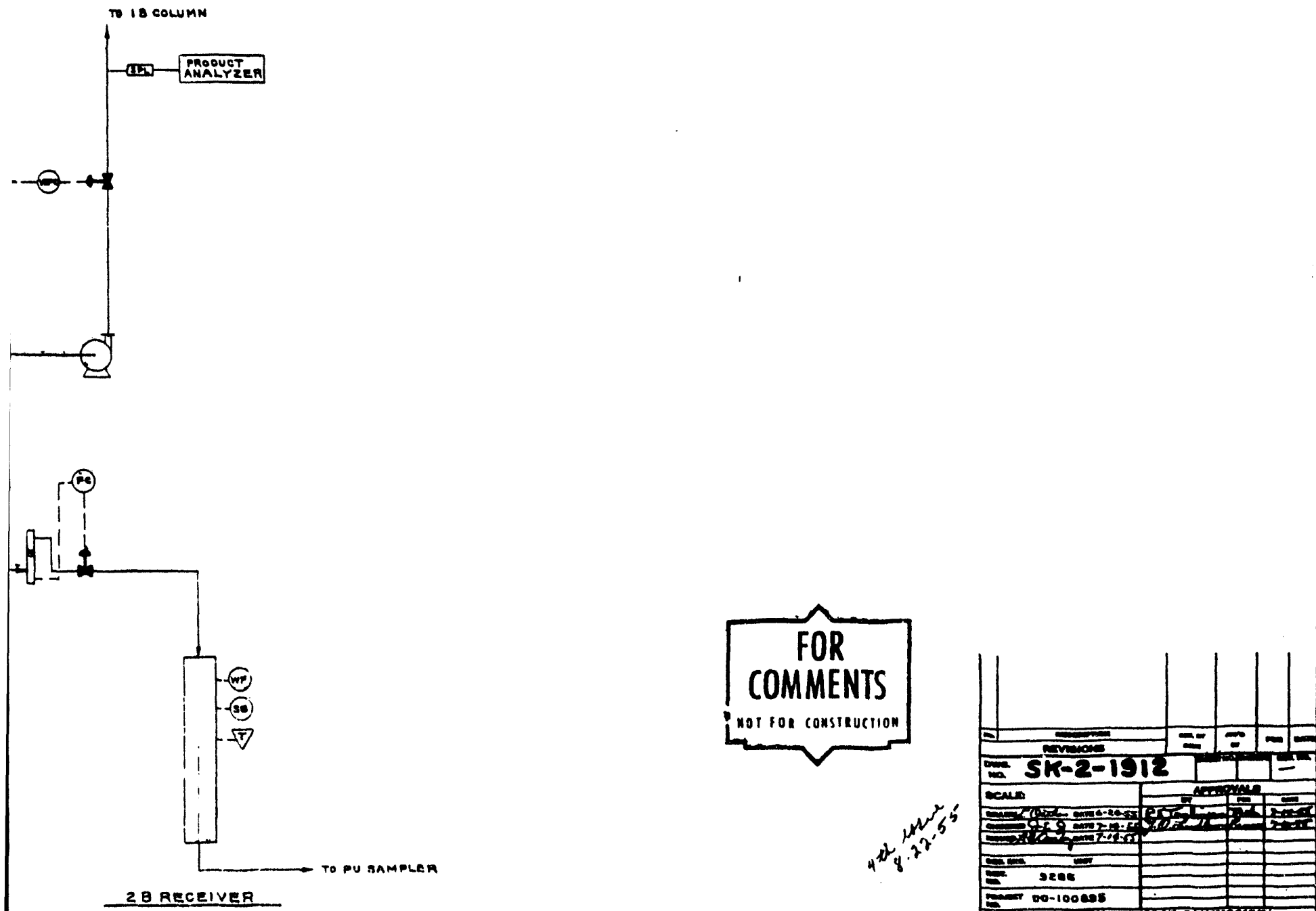

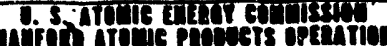
olumal clestaie

SECOND PU CTCLE PROCESS FLOW SKETAA NEW SEPA WATIONIS PLANT STUOT 


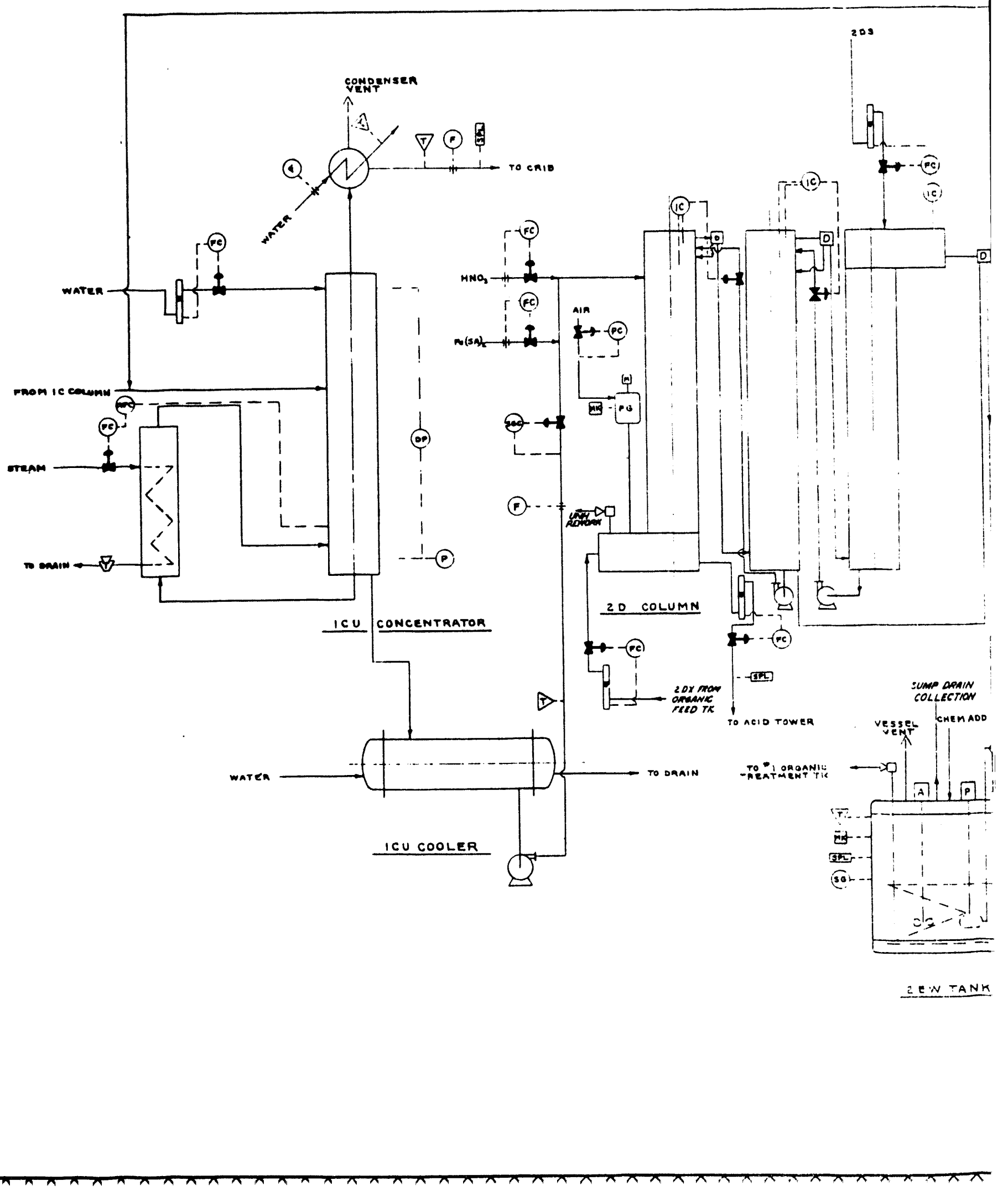




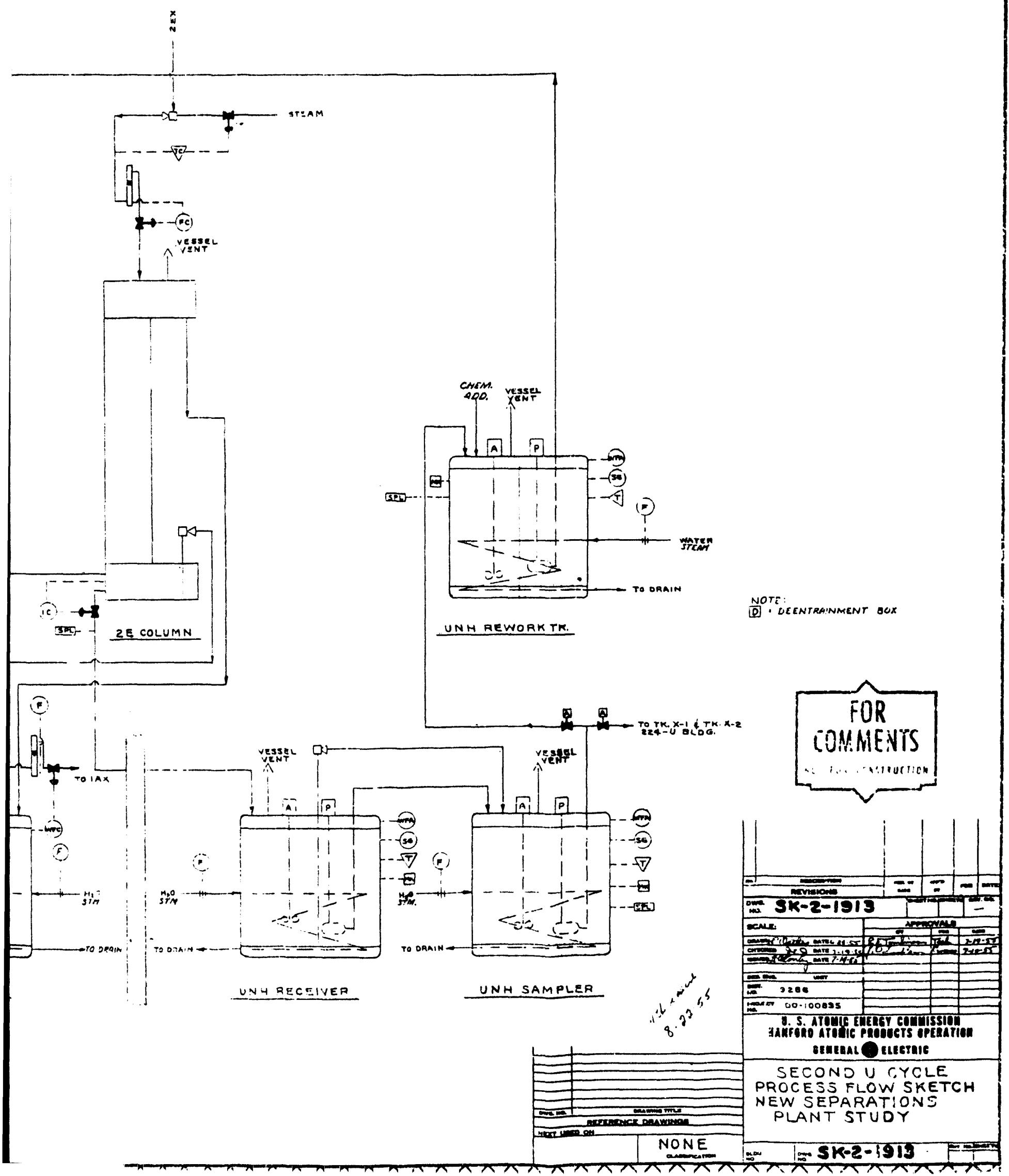




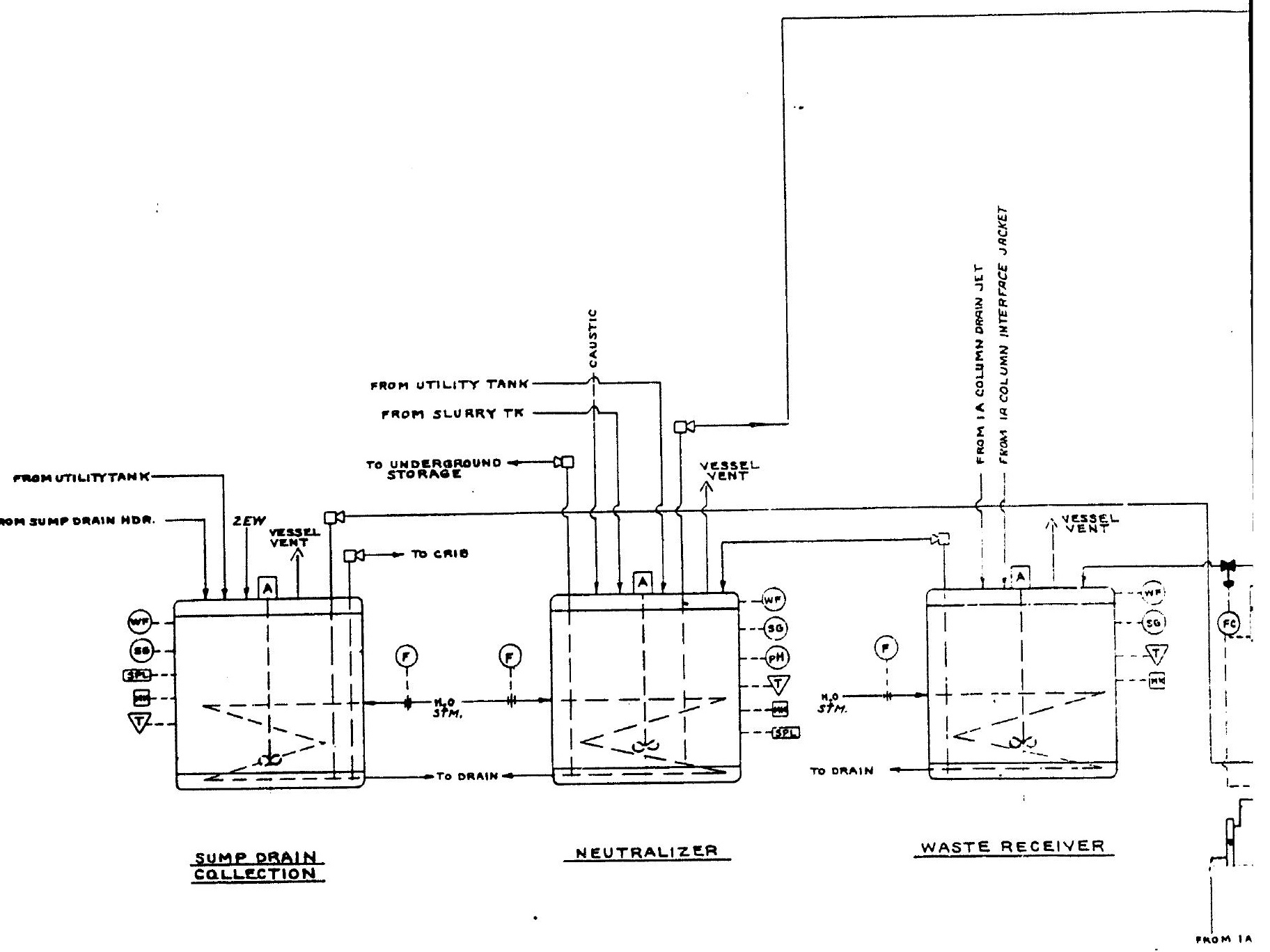


HW 38881

FAGE 62
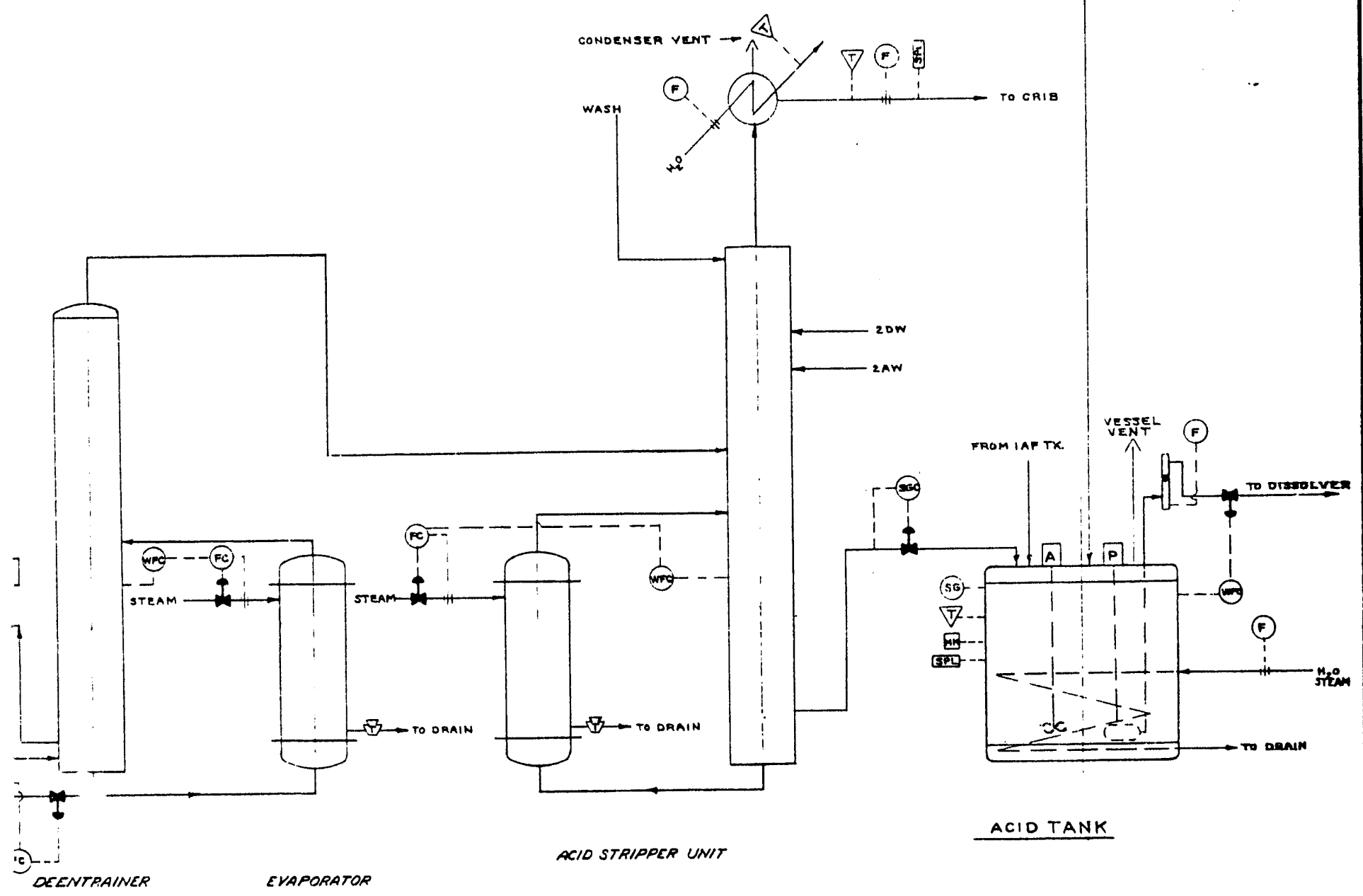

:OLUMN
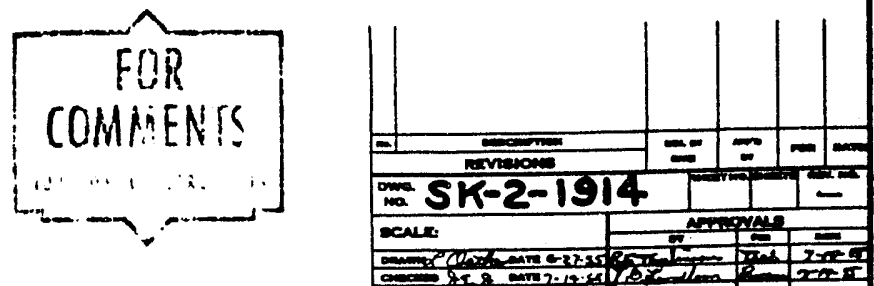

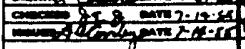

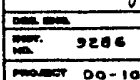

ACID TANK

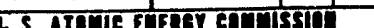

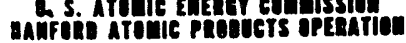
erazanal Oetegtaie

WASTE SECTION PROCESS FLOW SKETCH NEW SEPARATIONS PLANT STUDY 


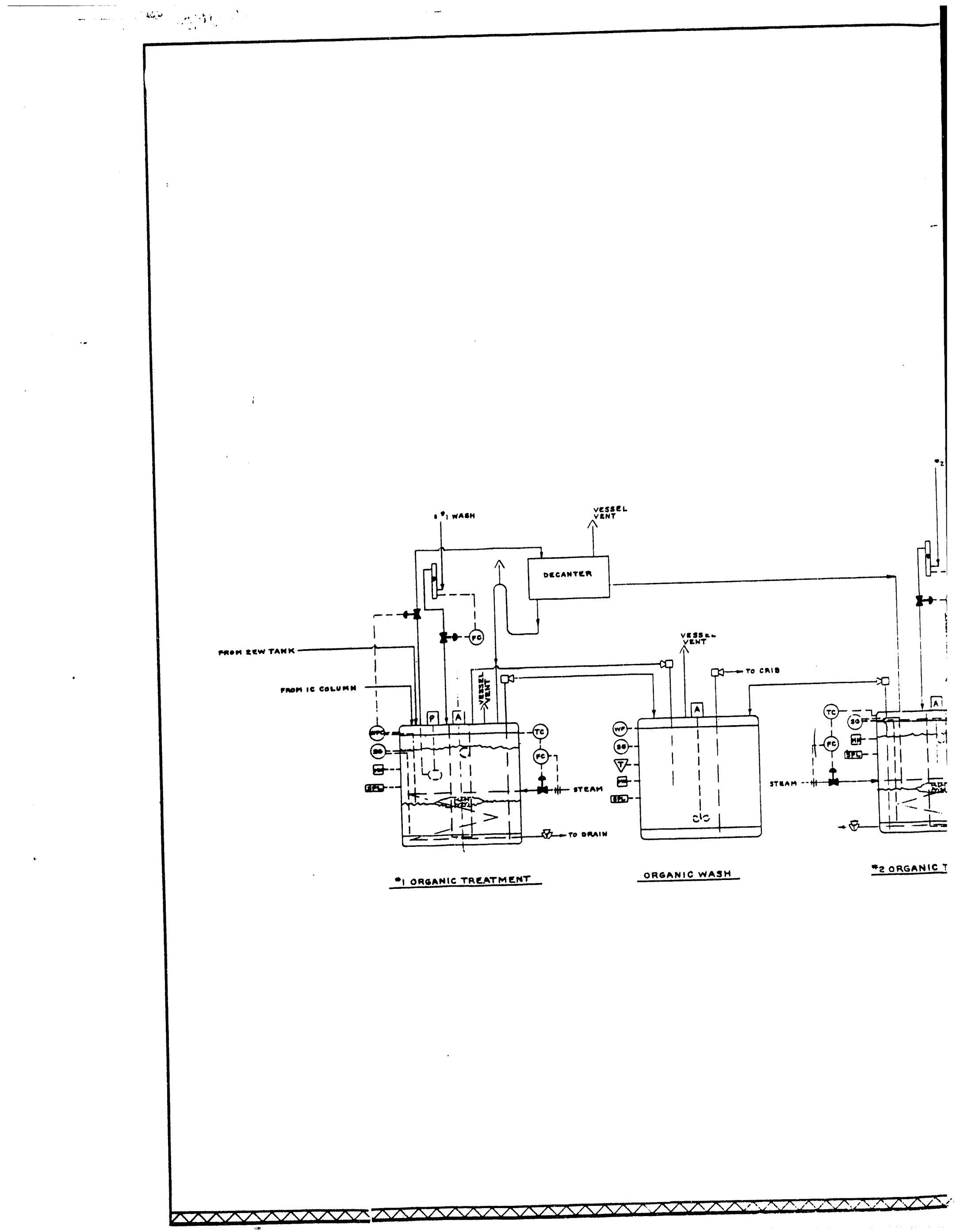


HW 38881

PA.GE 63
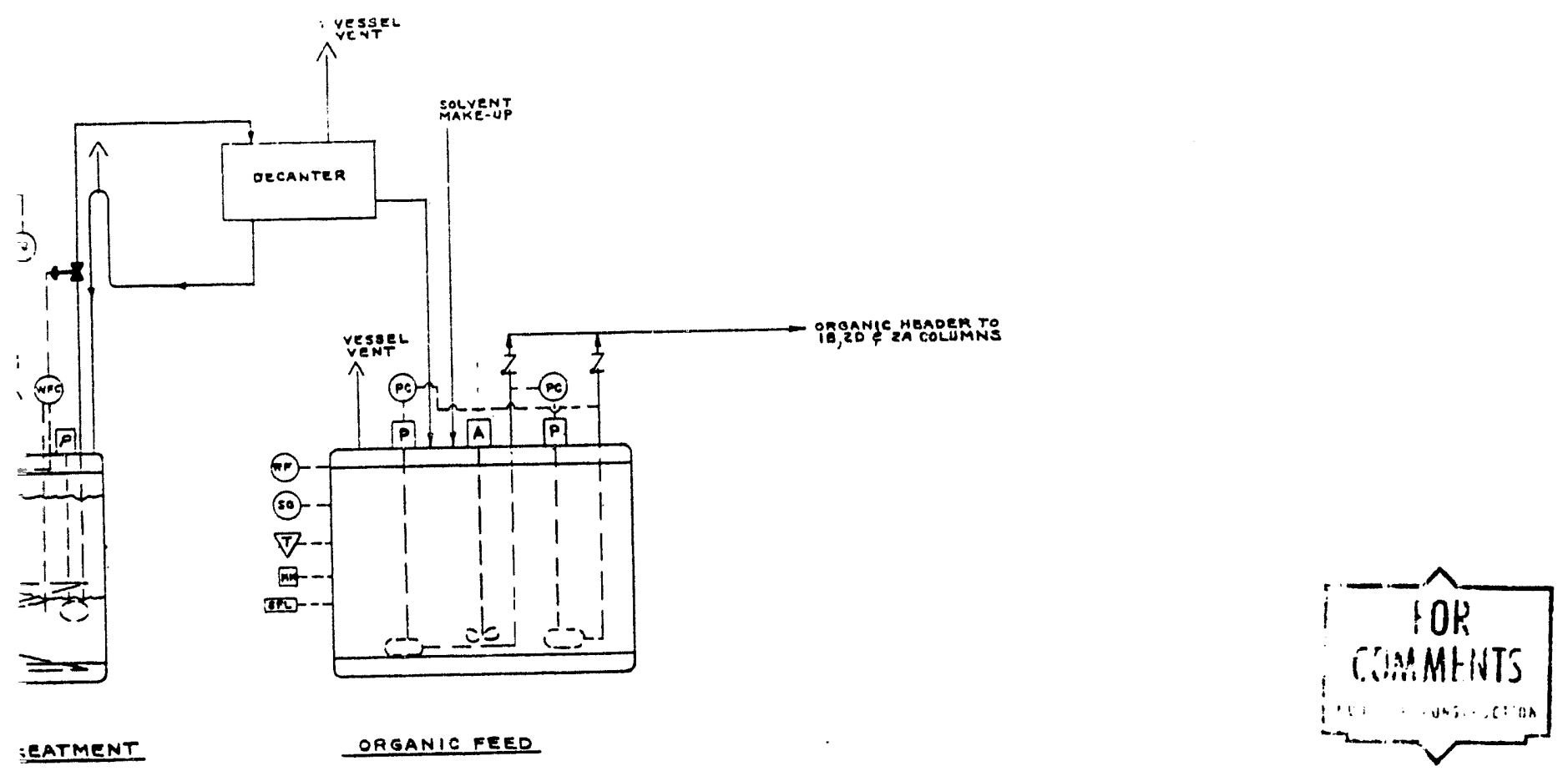


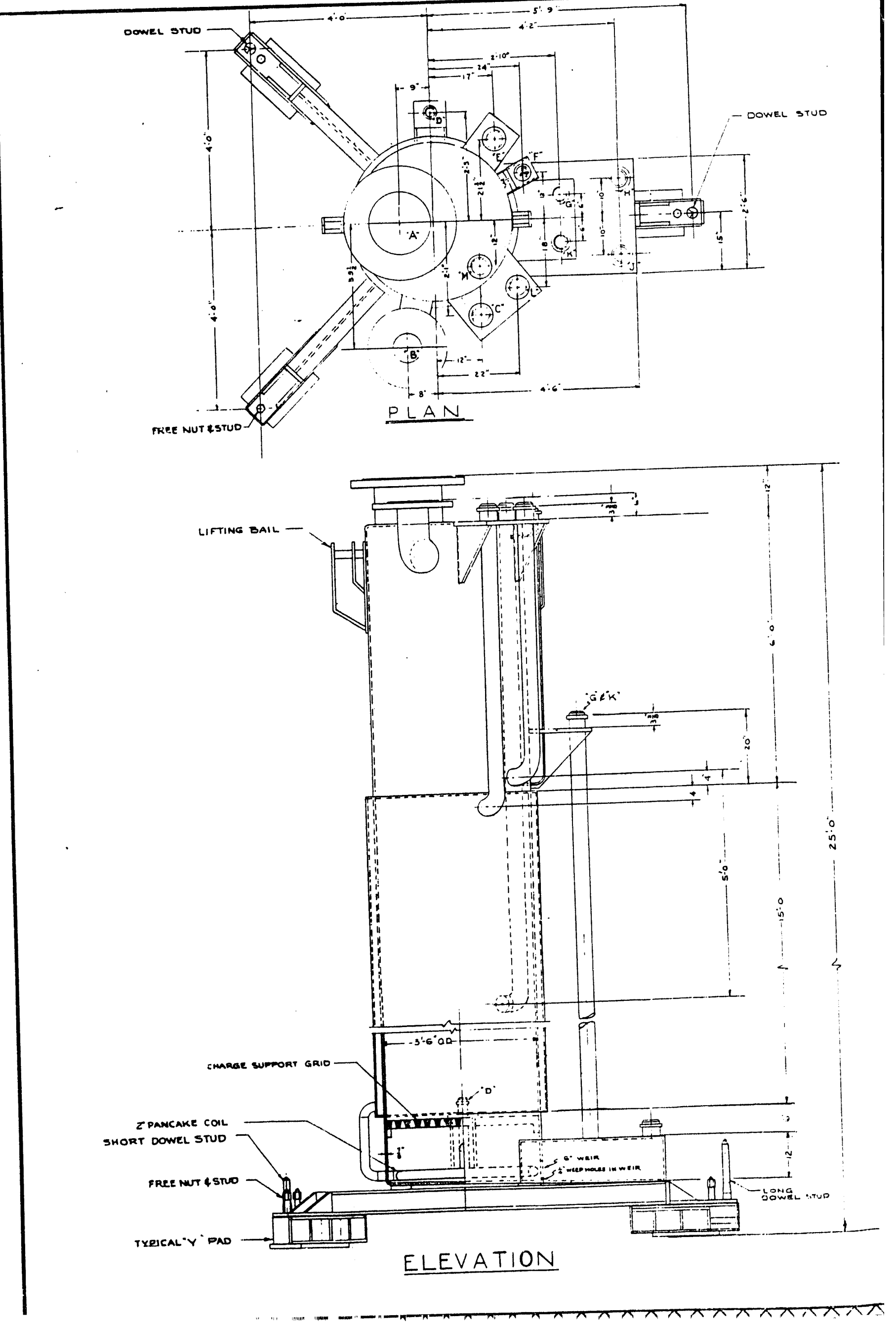


NOZZLE LEGEND

A- FIll chute $\ldots \ldots \ldots$ - 18 CIA. Flanged

B- - JACKET STEAM IN -

C- JACKET STEAM OUT -

- FRESH ACIO.

DIFFERENTIAL ORESSURE-:-

$-\overline{-1}-1$

SPARE JET

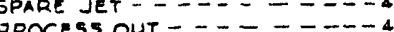

WT EACTOR SPGRAVTY

REFLUX ACIO - - - - - . -

CHEMICAL ADO . . . . . . ....4
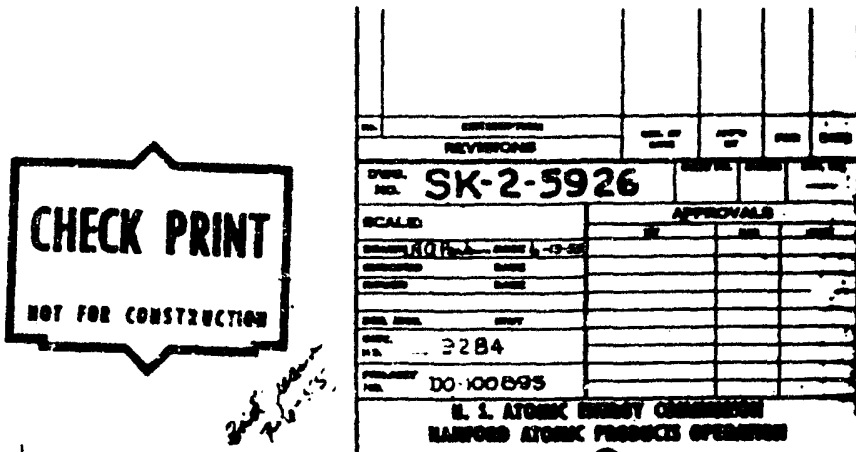

ozukat surme

CONTINUOUS

DISSOLVER 


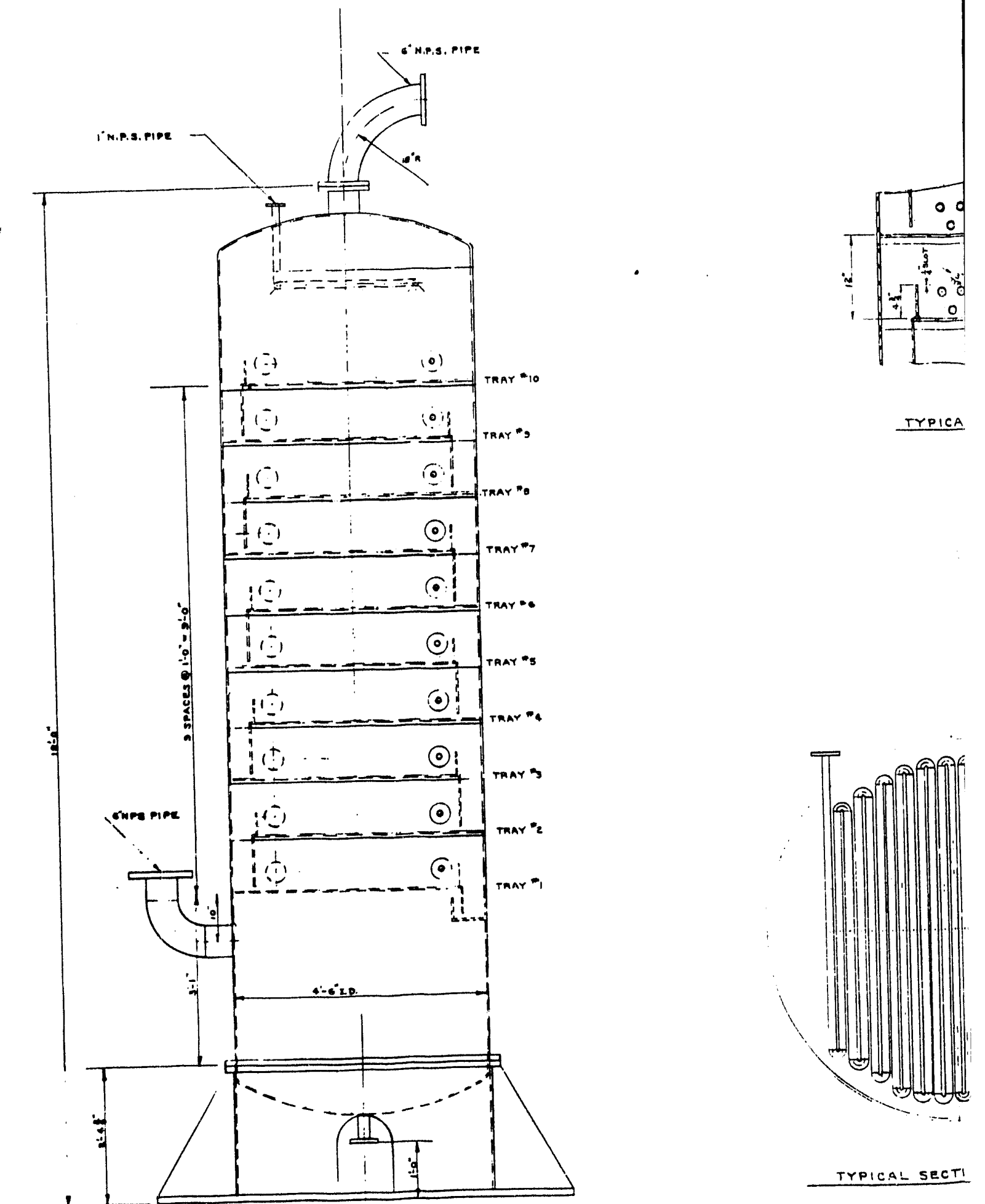




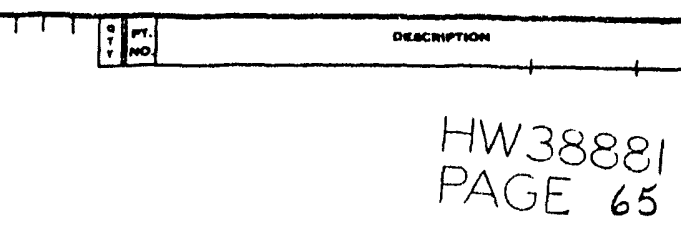

- 000000000

00000000000

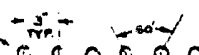

0000000000001

- inps pipe

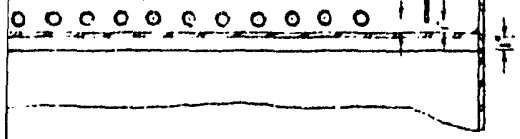

- HALF SECTION SHOWING TRAYS
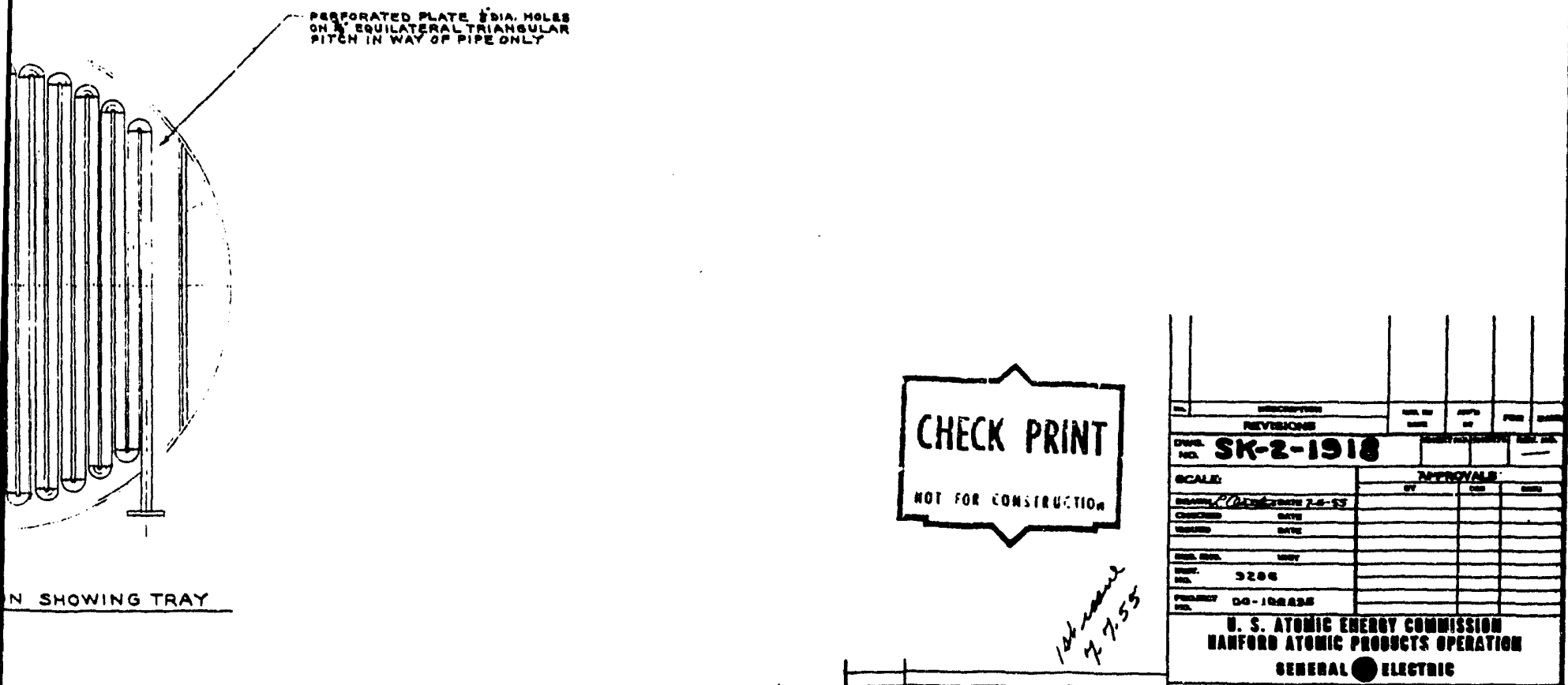

N SHOWING TRAY

DISSOLVER OFF-GAS AESORBEA 


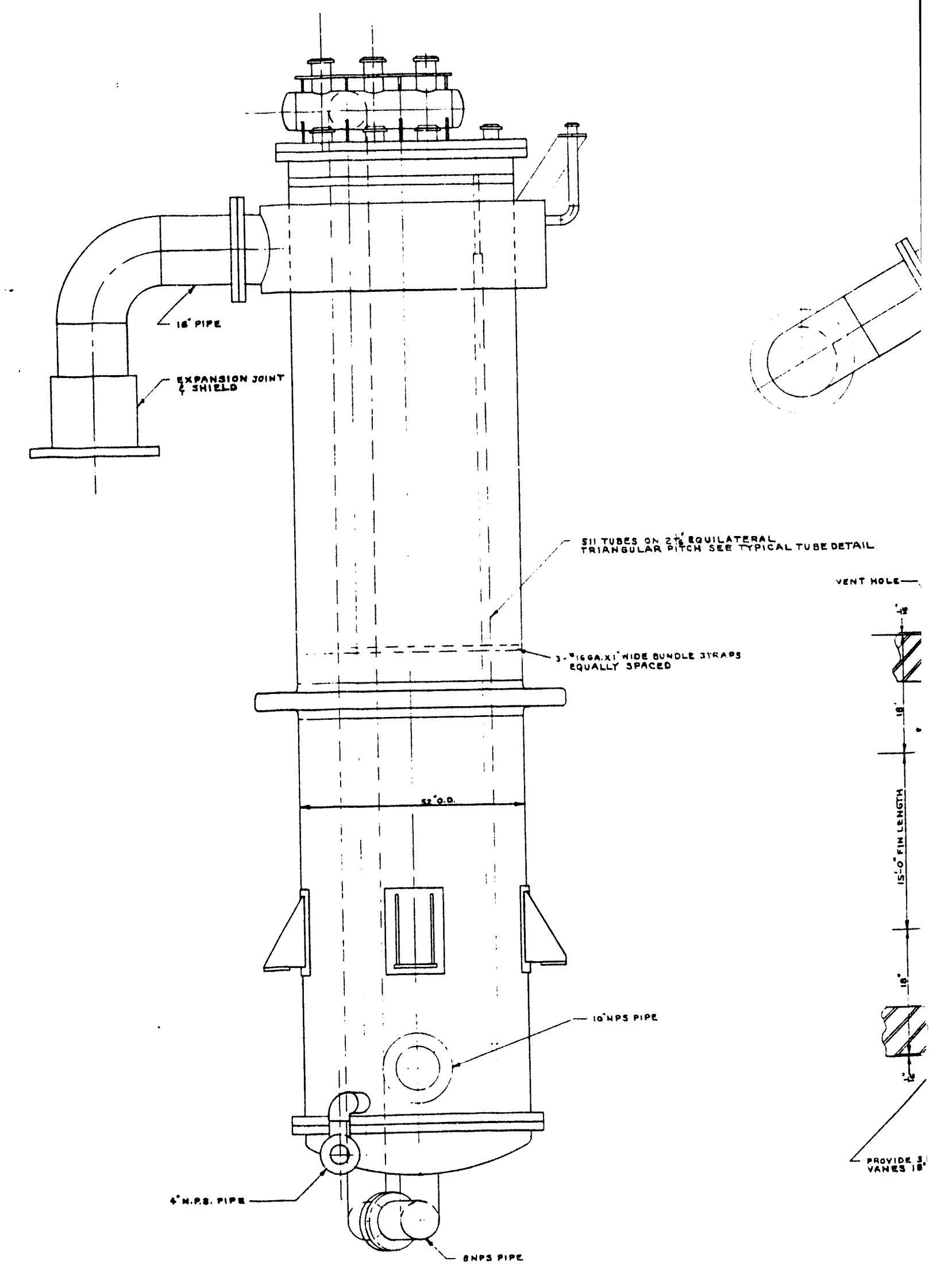




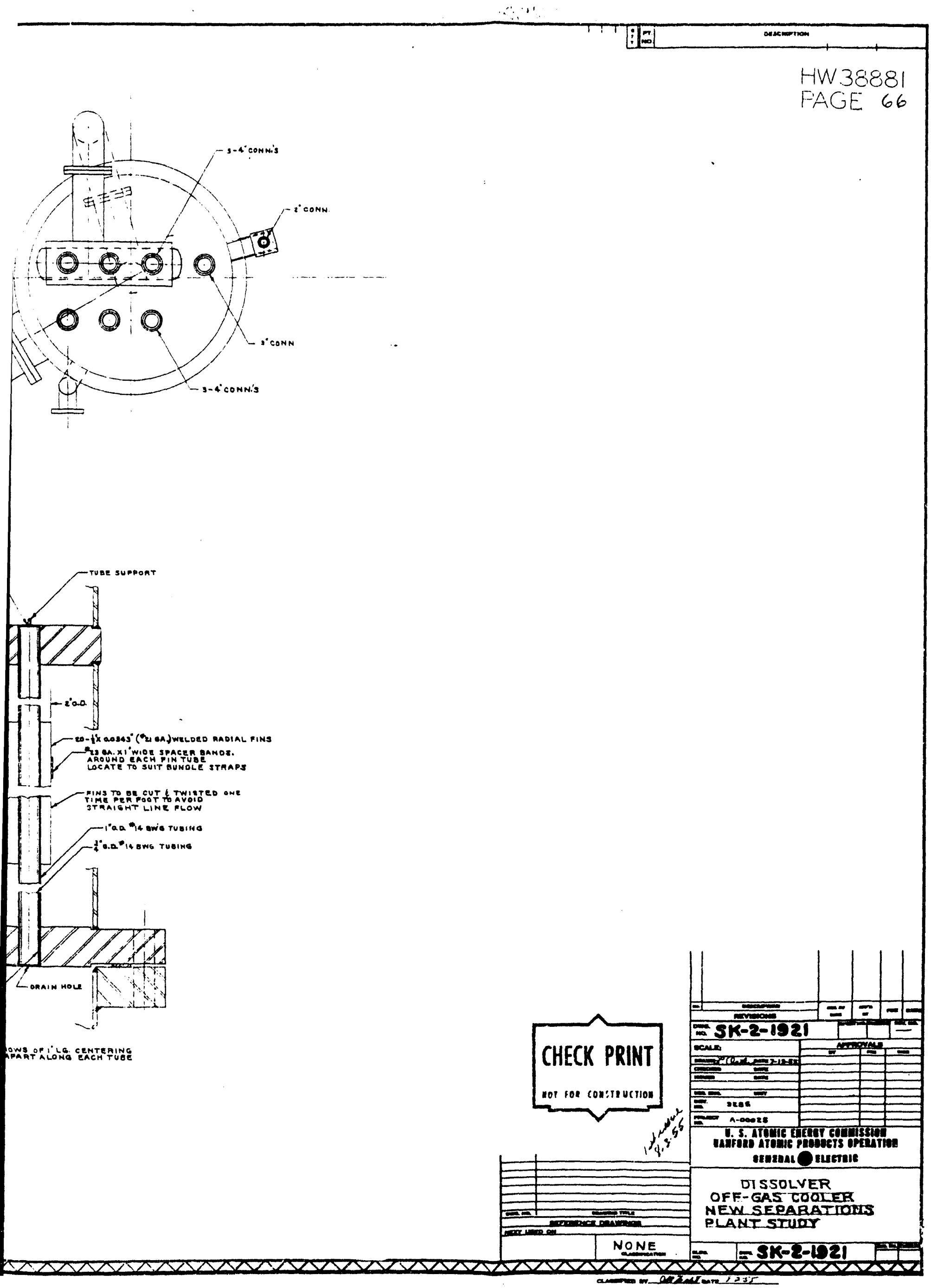




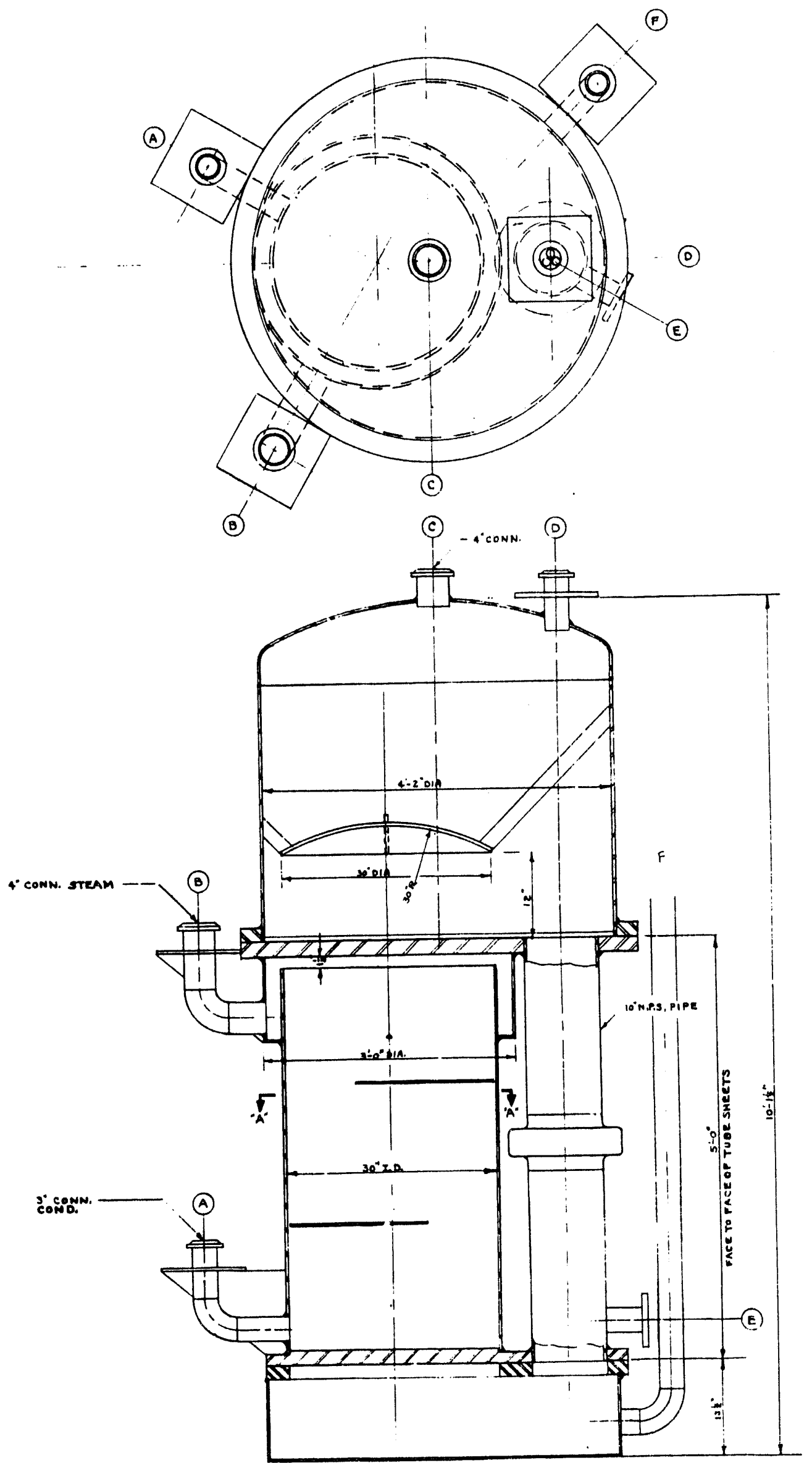


HW 388,3

PAGE 61
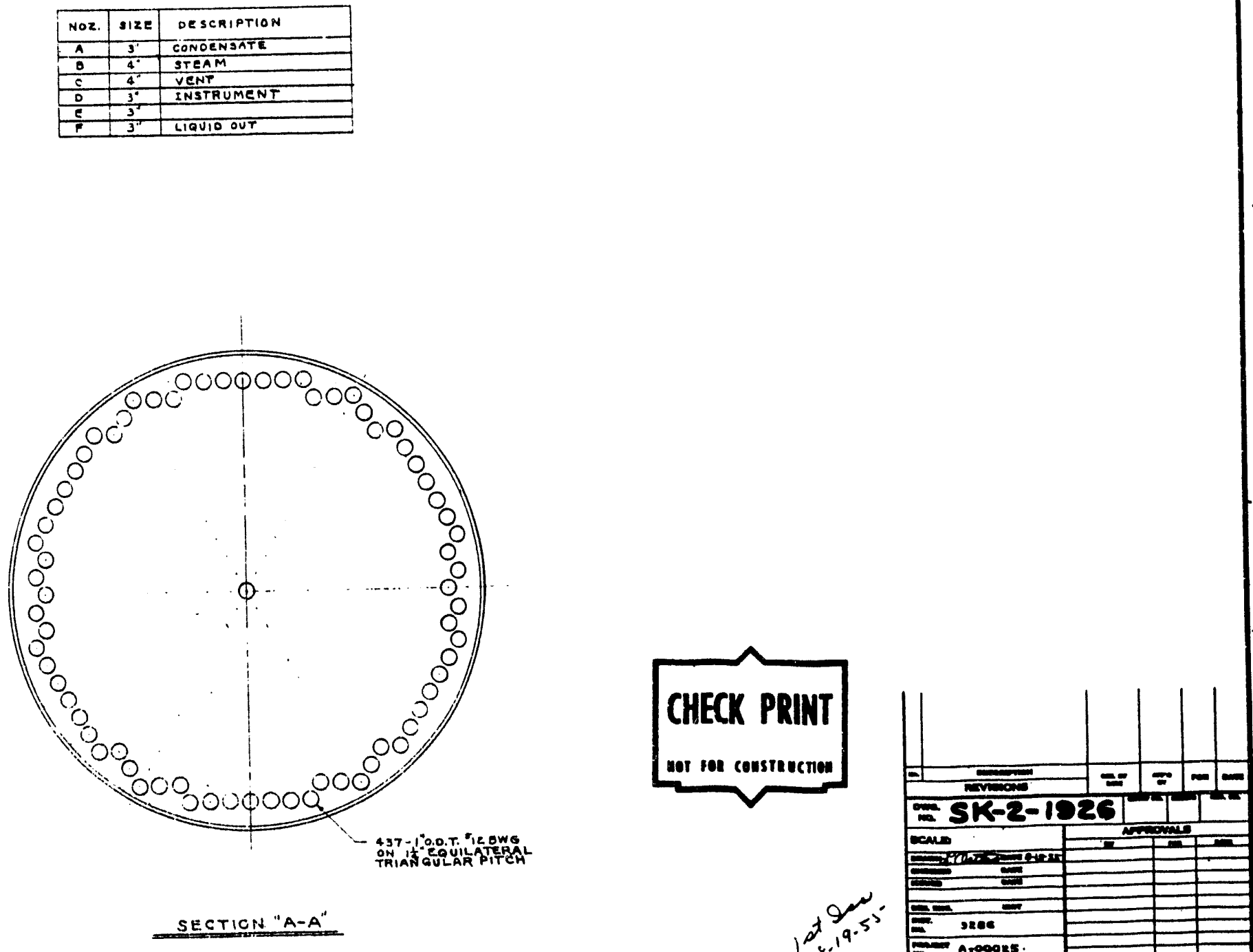

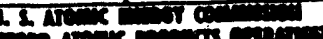
ctutuat suremie

CONCENTRATOR NEW SEPARATIONS PLANT STUOT 

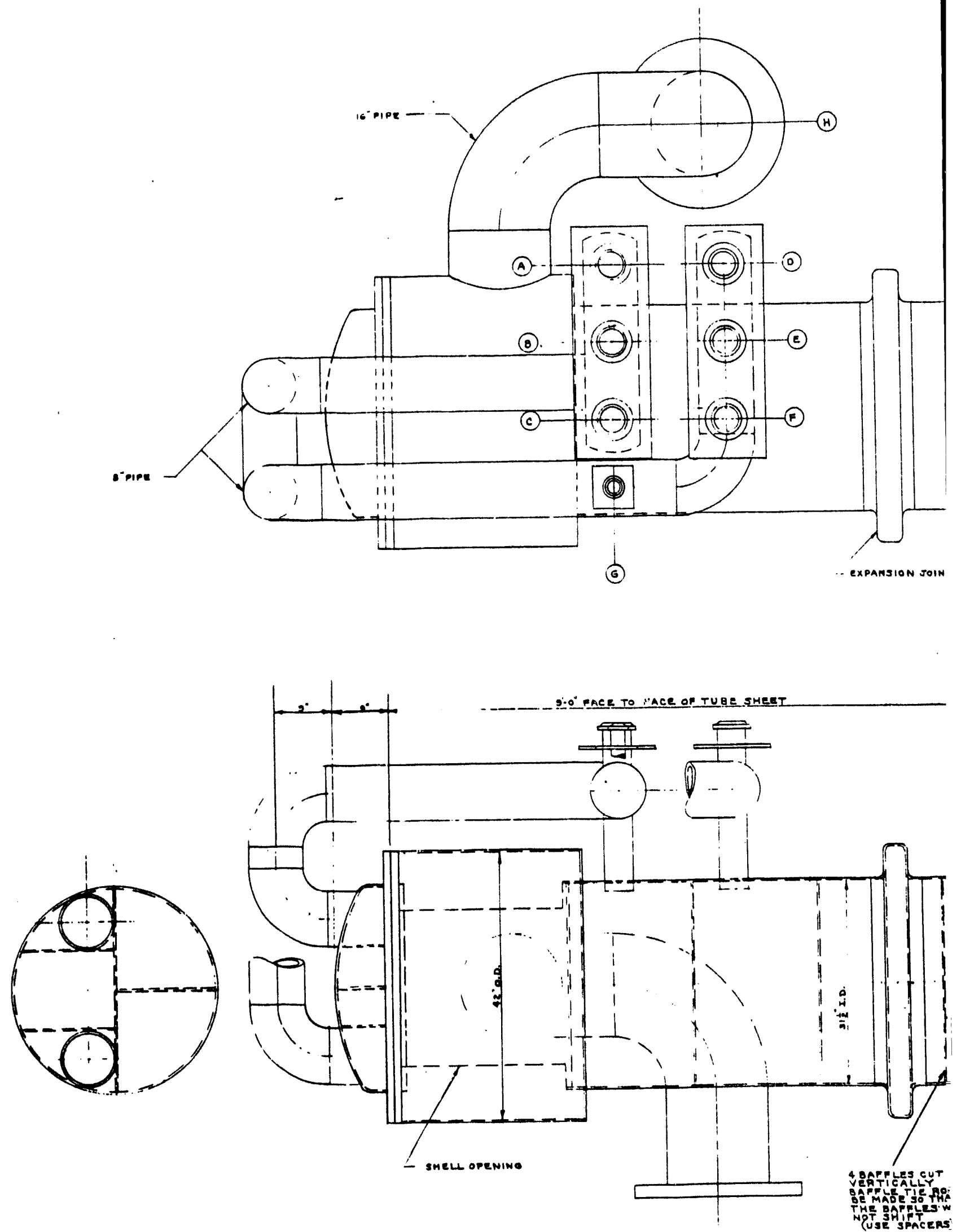

$\Theta$ 
iㅛㄹㅣ

(J)

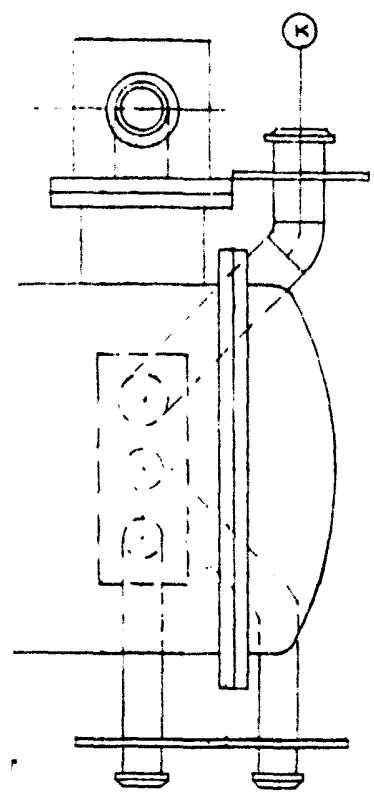

(C) (M)

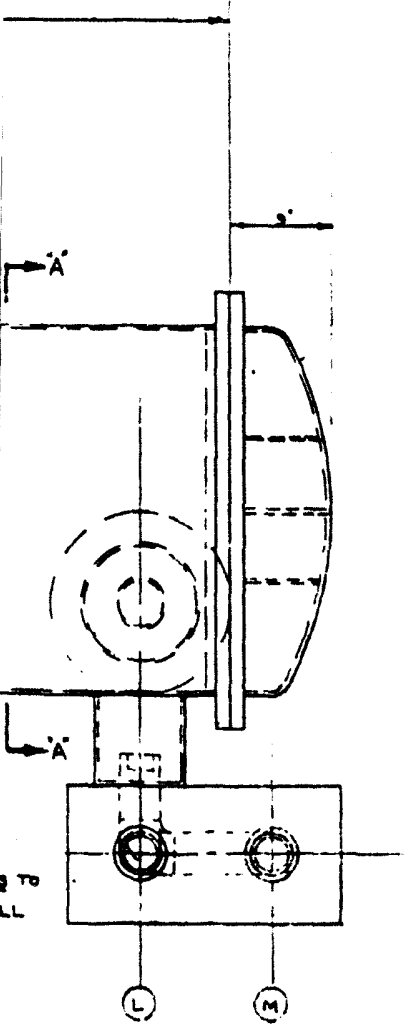

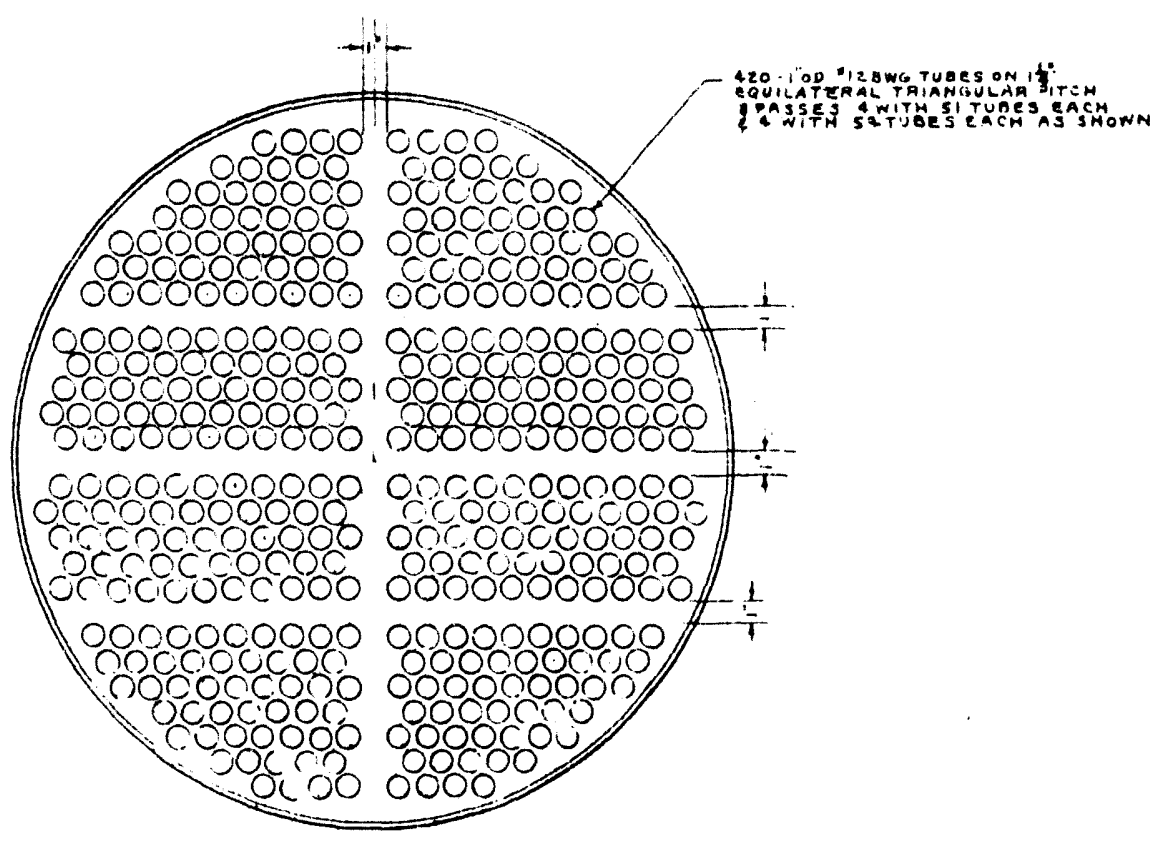
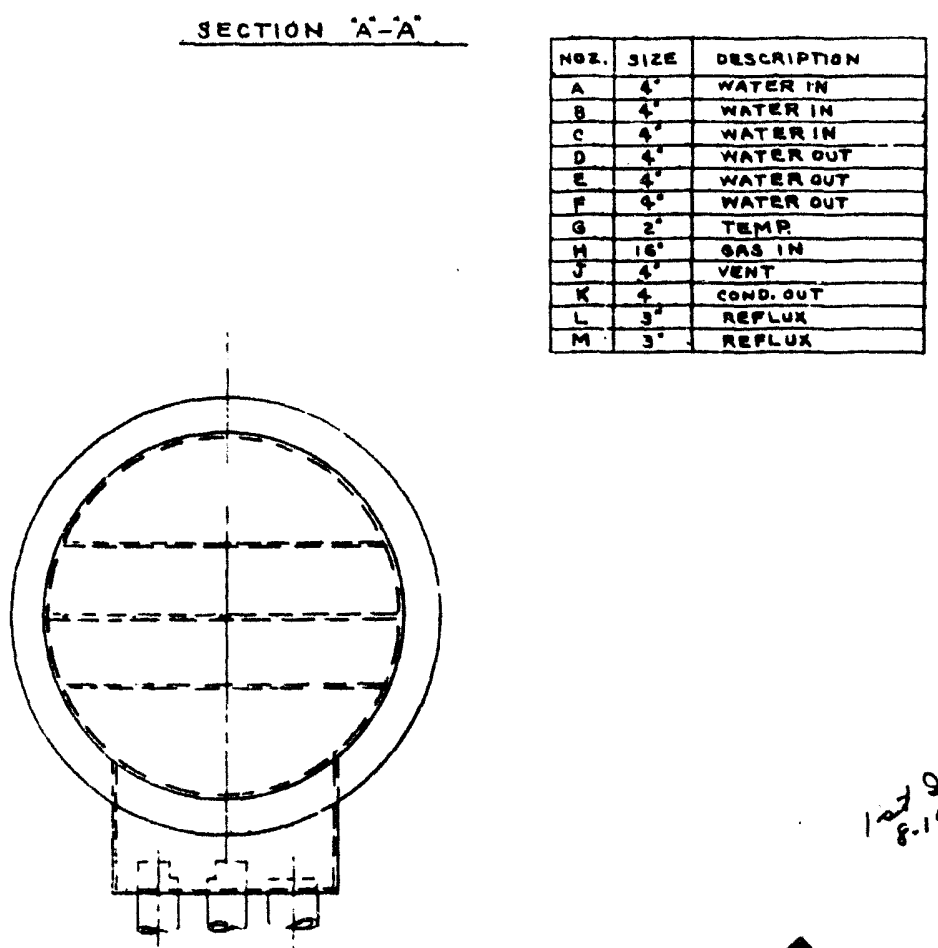

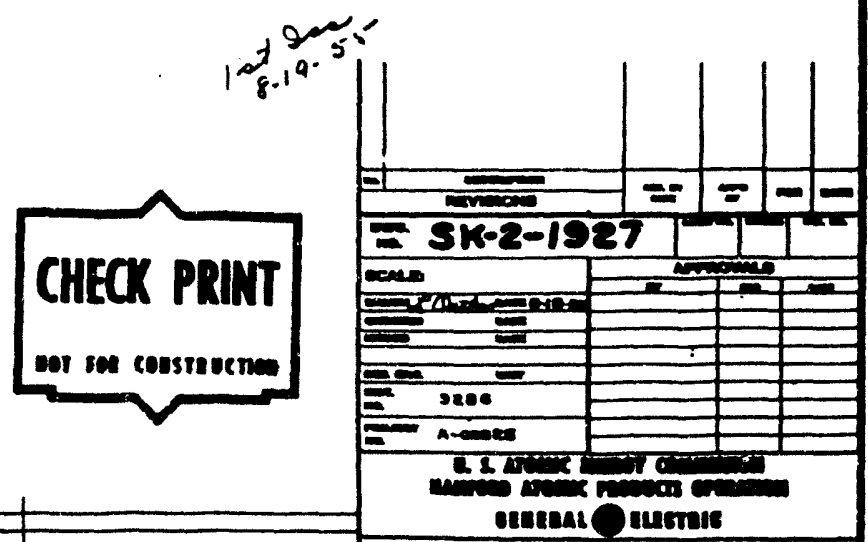

CONDENSER

NEW SEPARATIONS PLANT STURY 

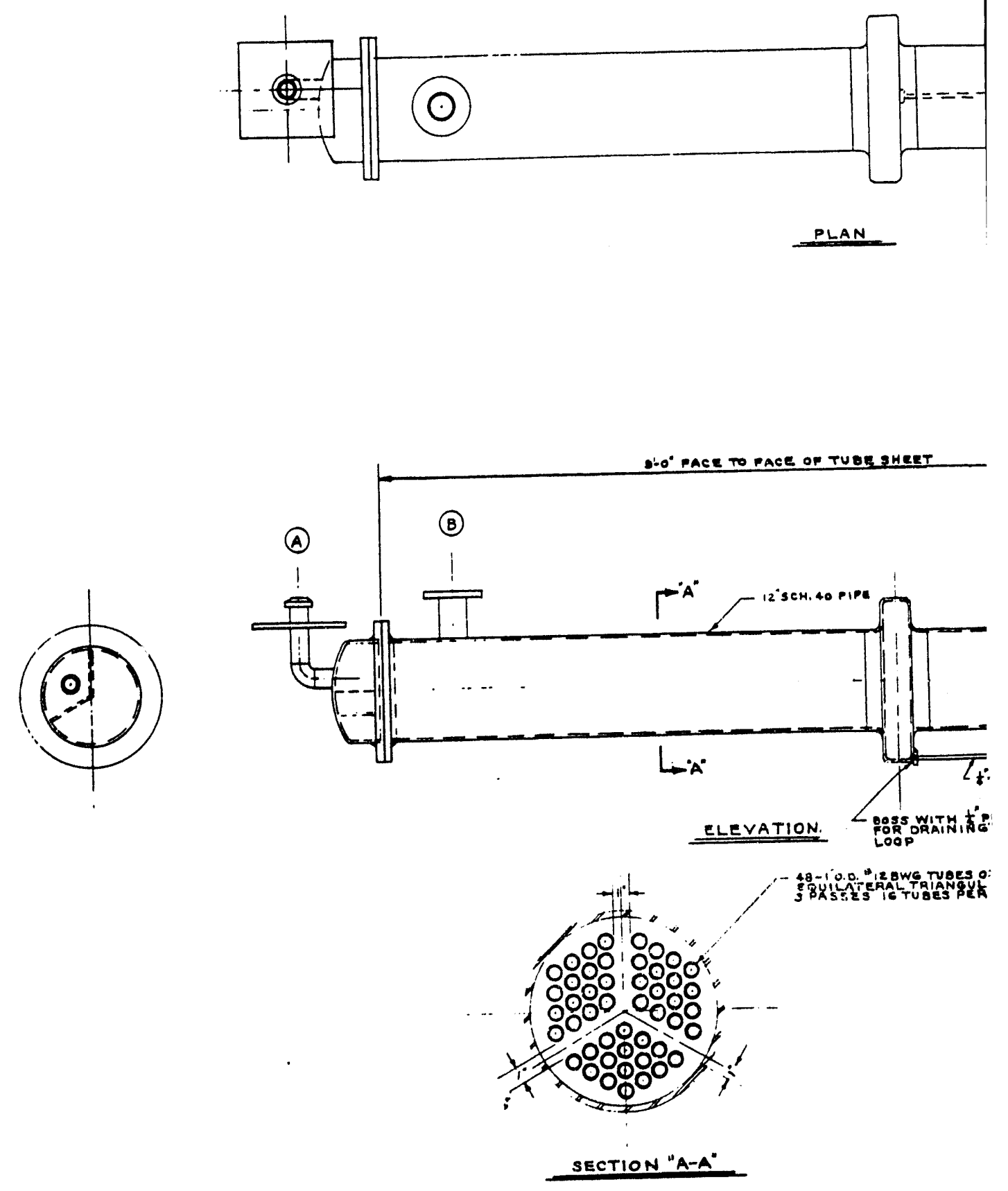
HW 38881

PAGE 6?
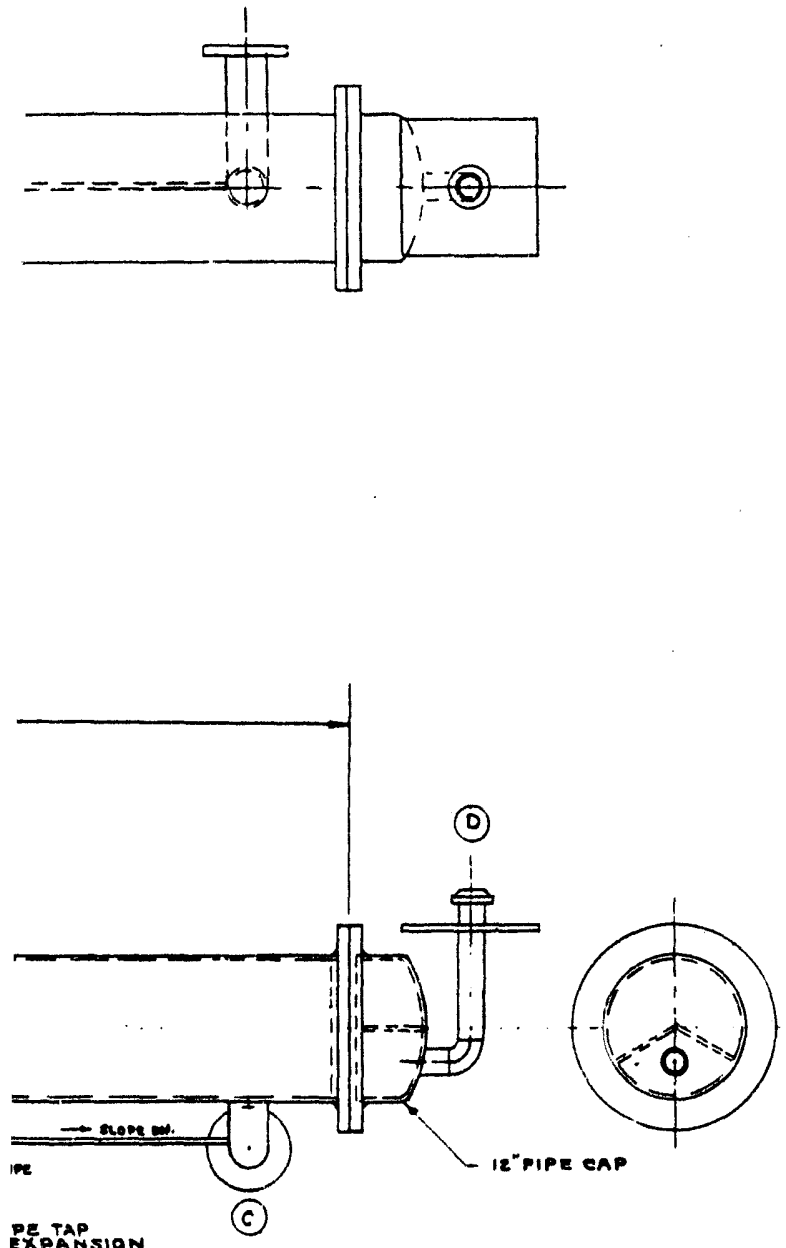

PEPAAPSION

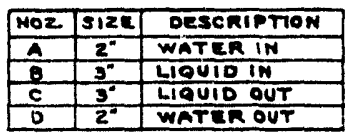

PÁsiten

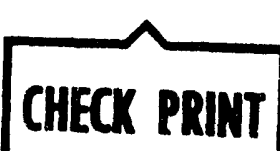

not ber constevecne
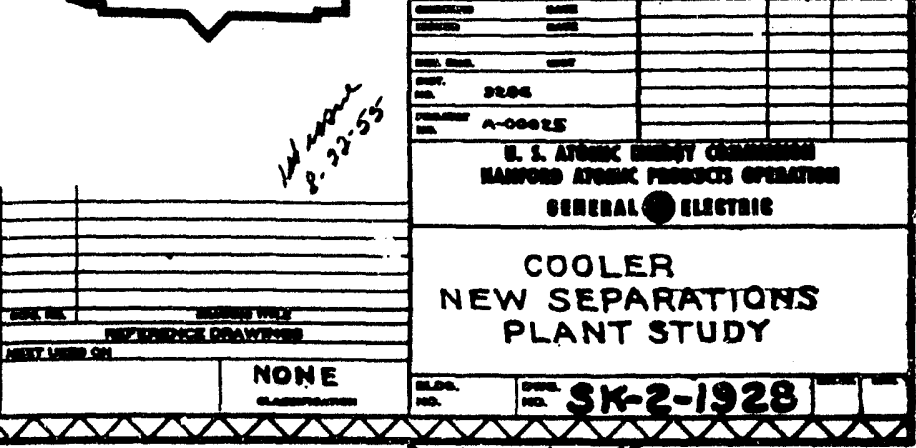

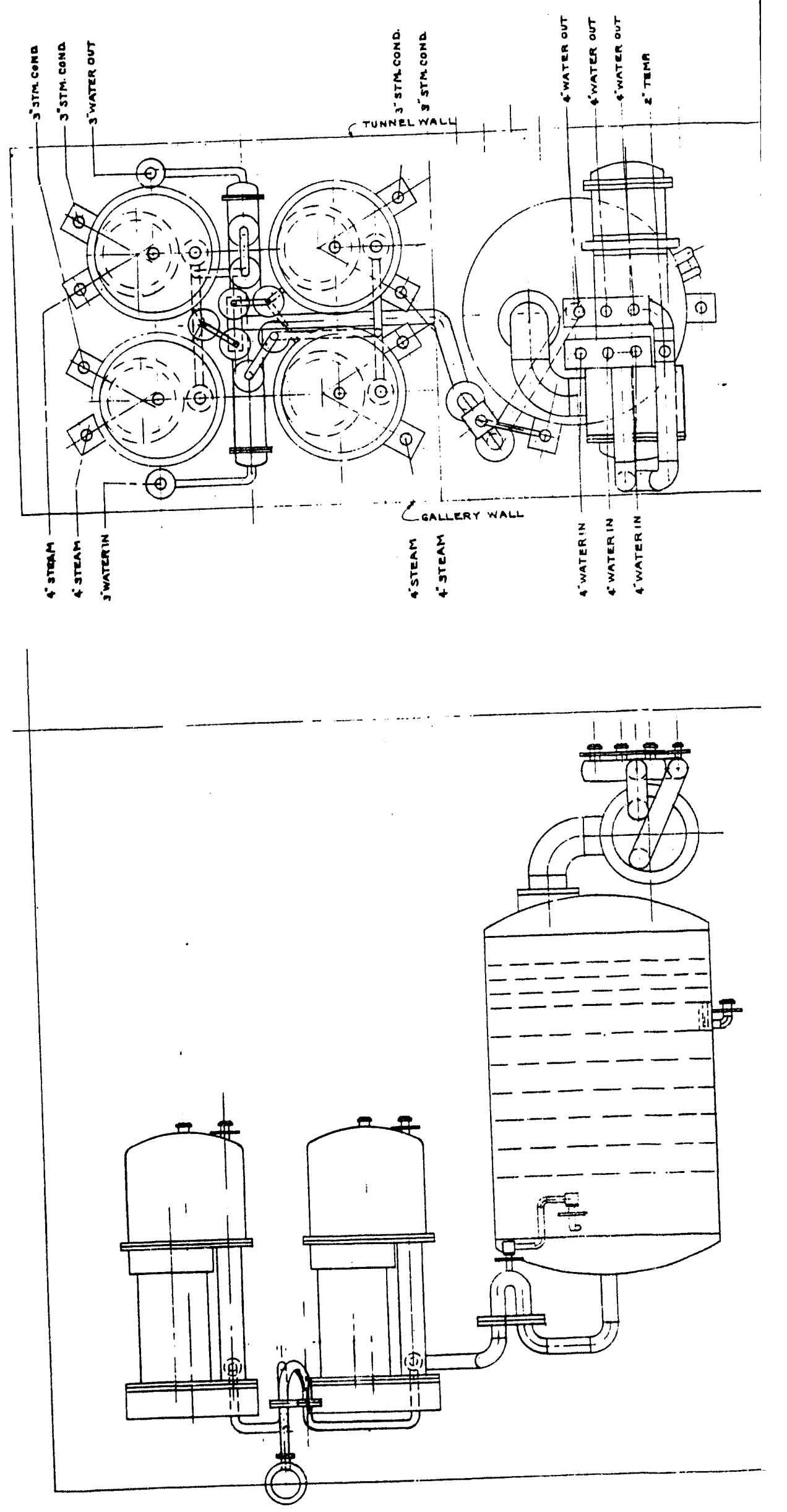
HW 38881

PAGE 70

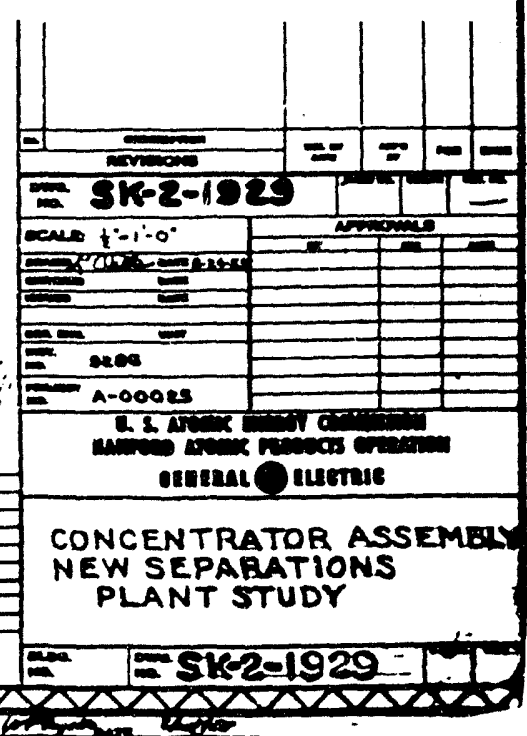


(c)
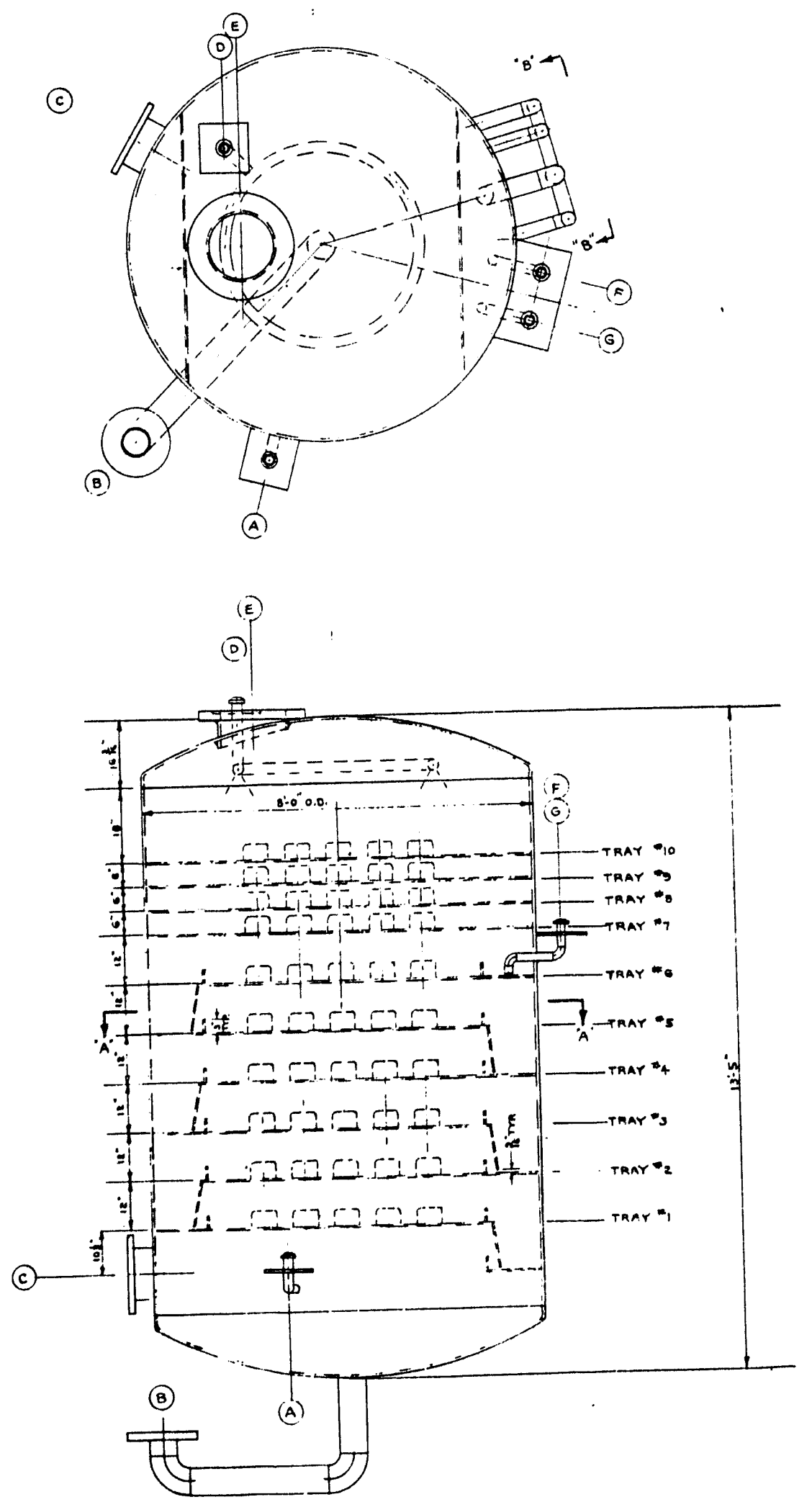

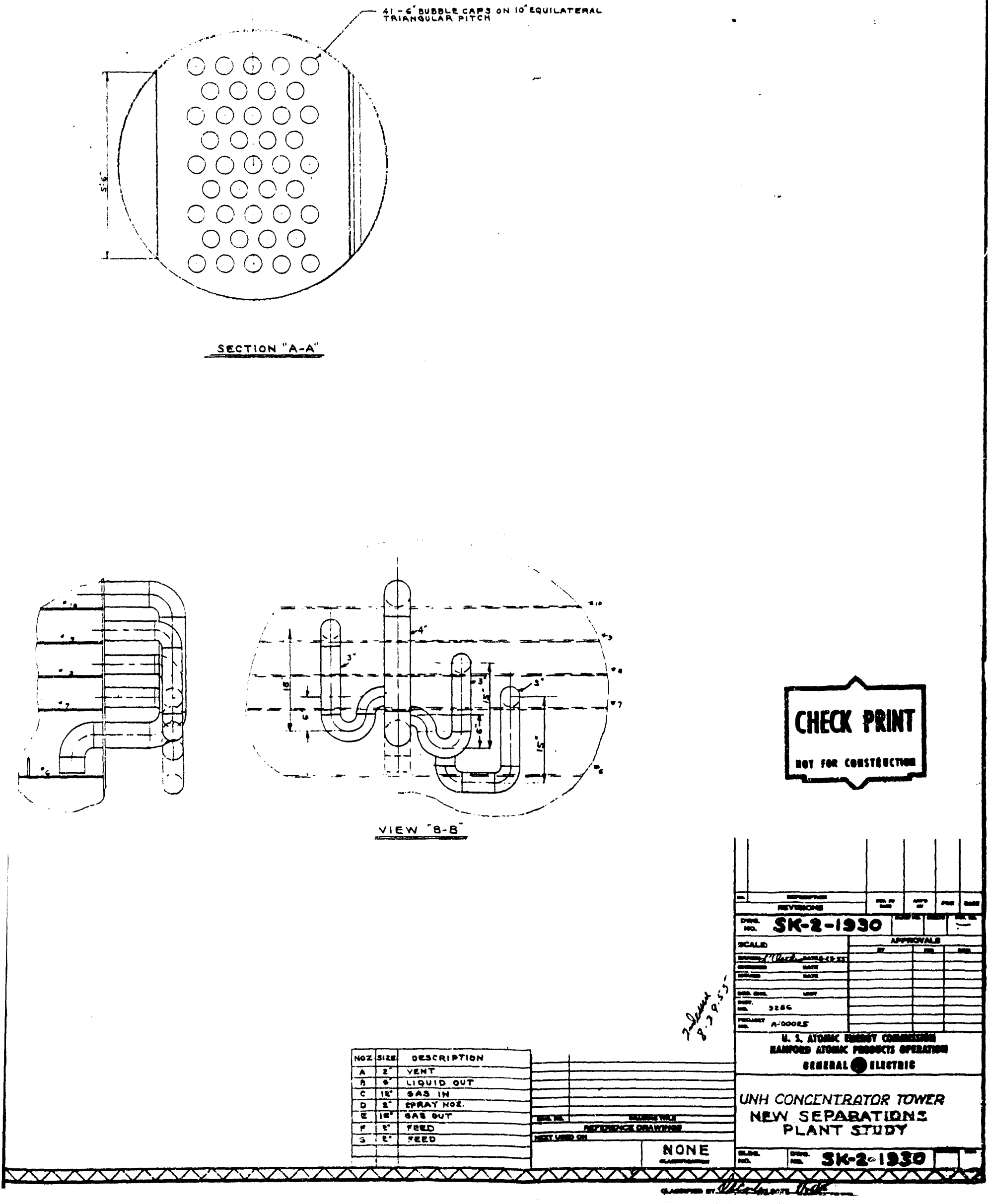


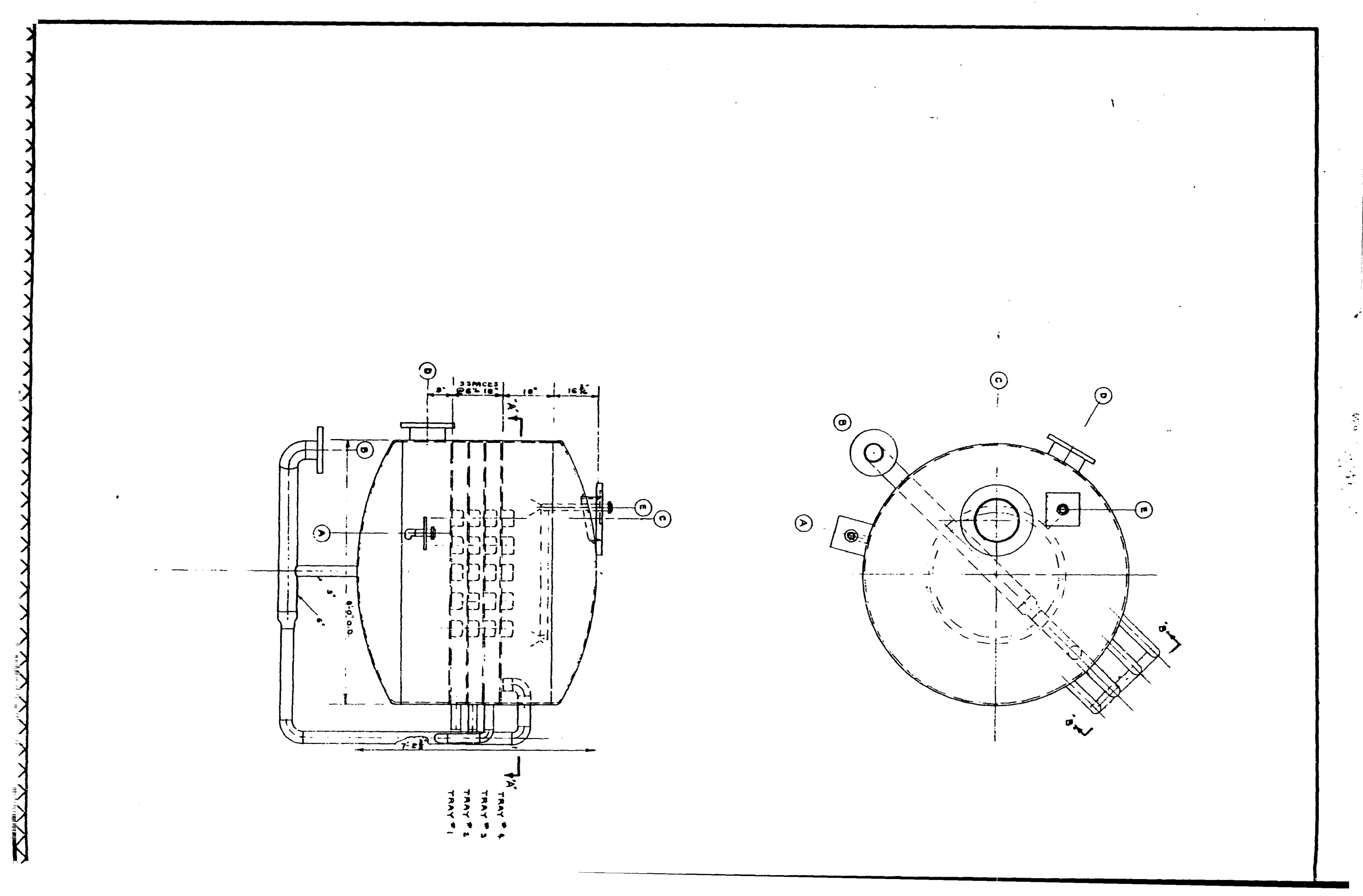




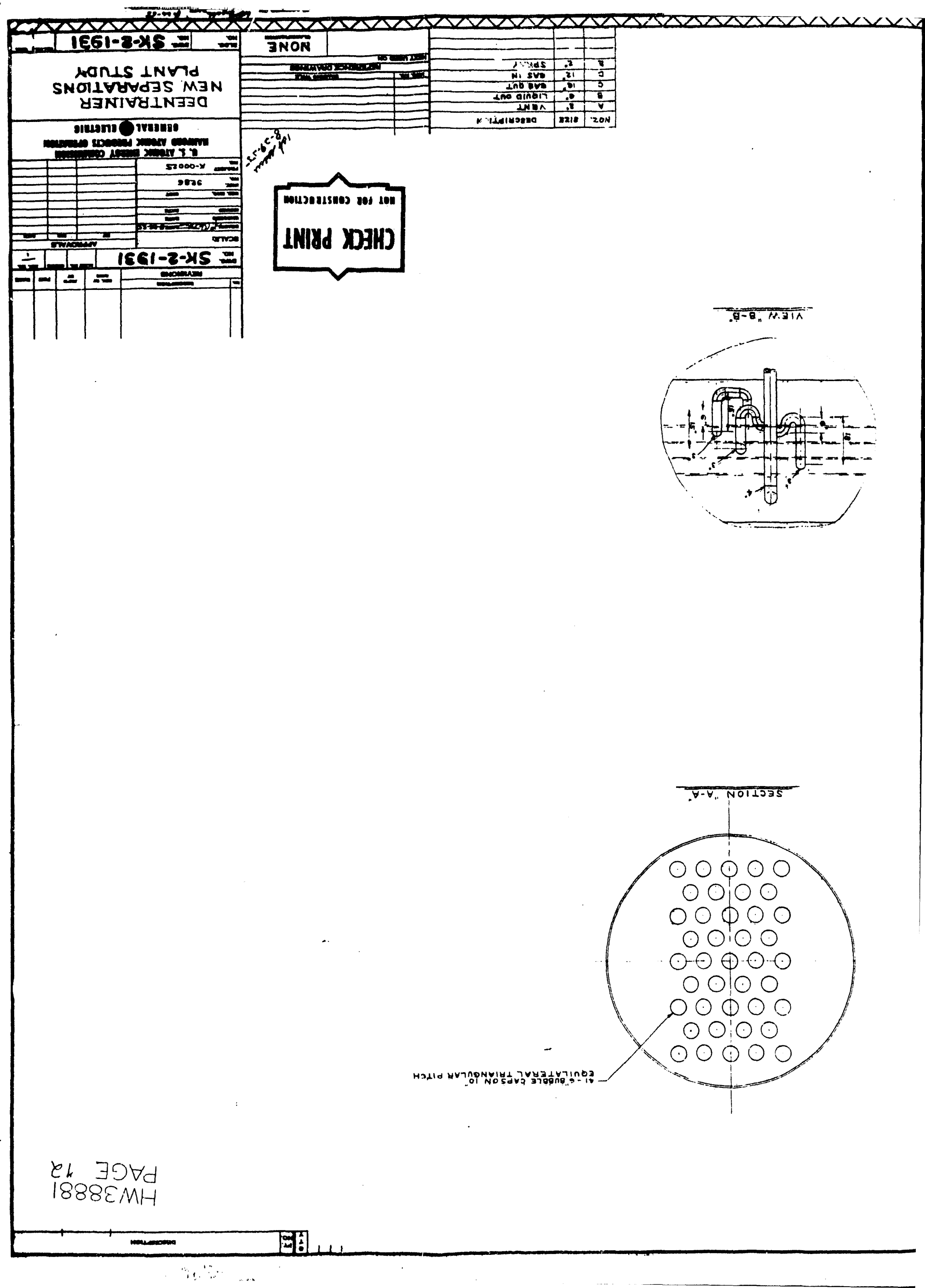



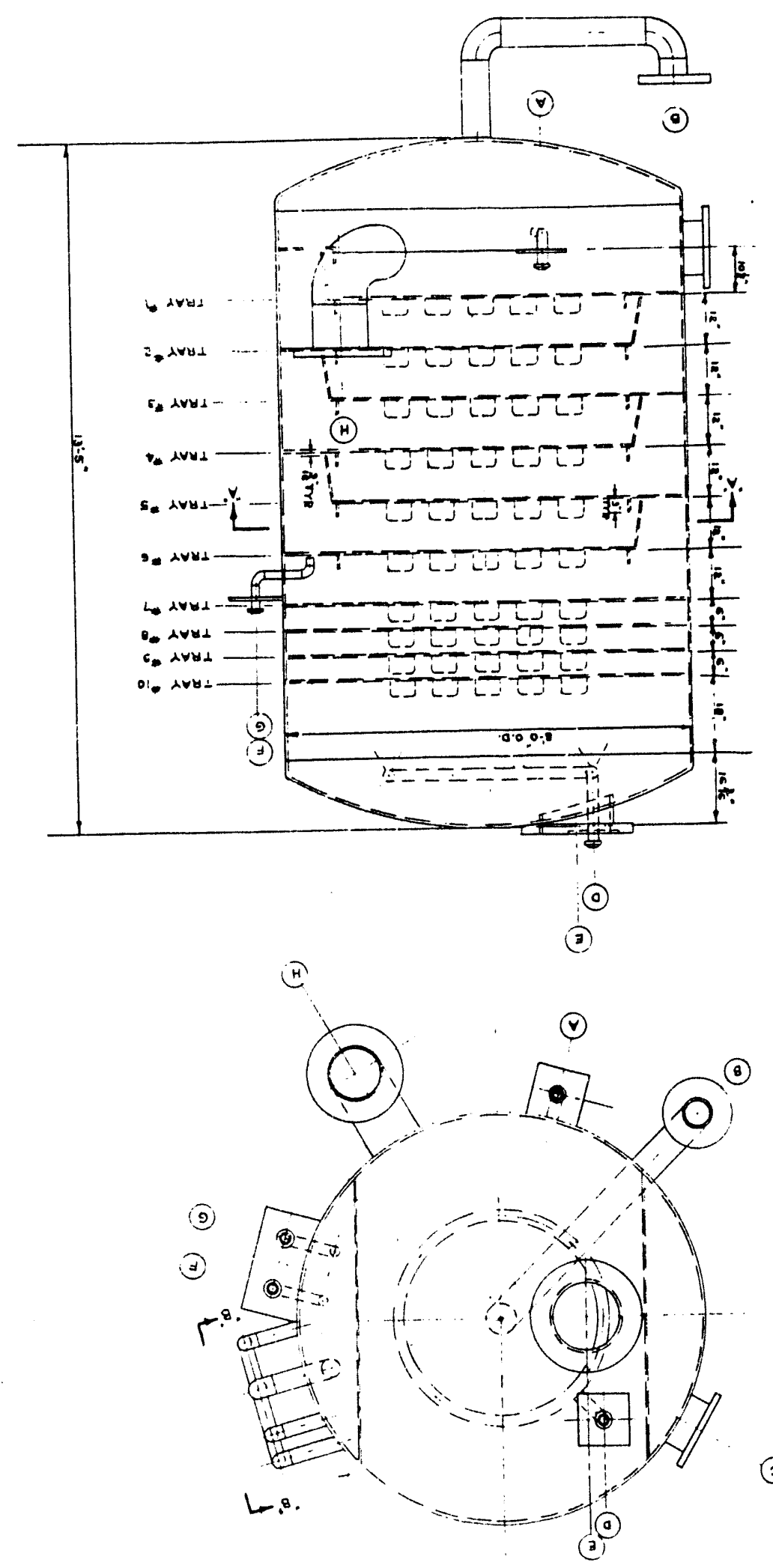
HW 38881

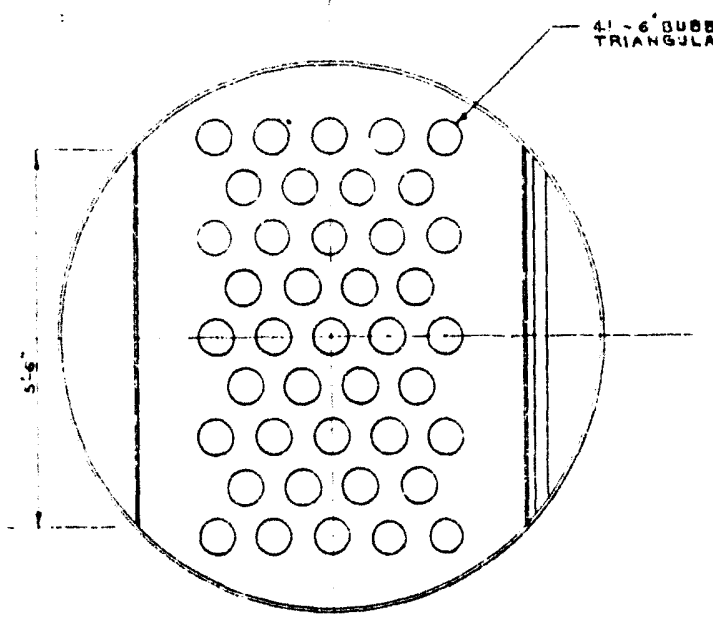

SECTION A-A"
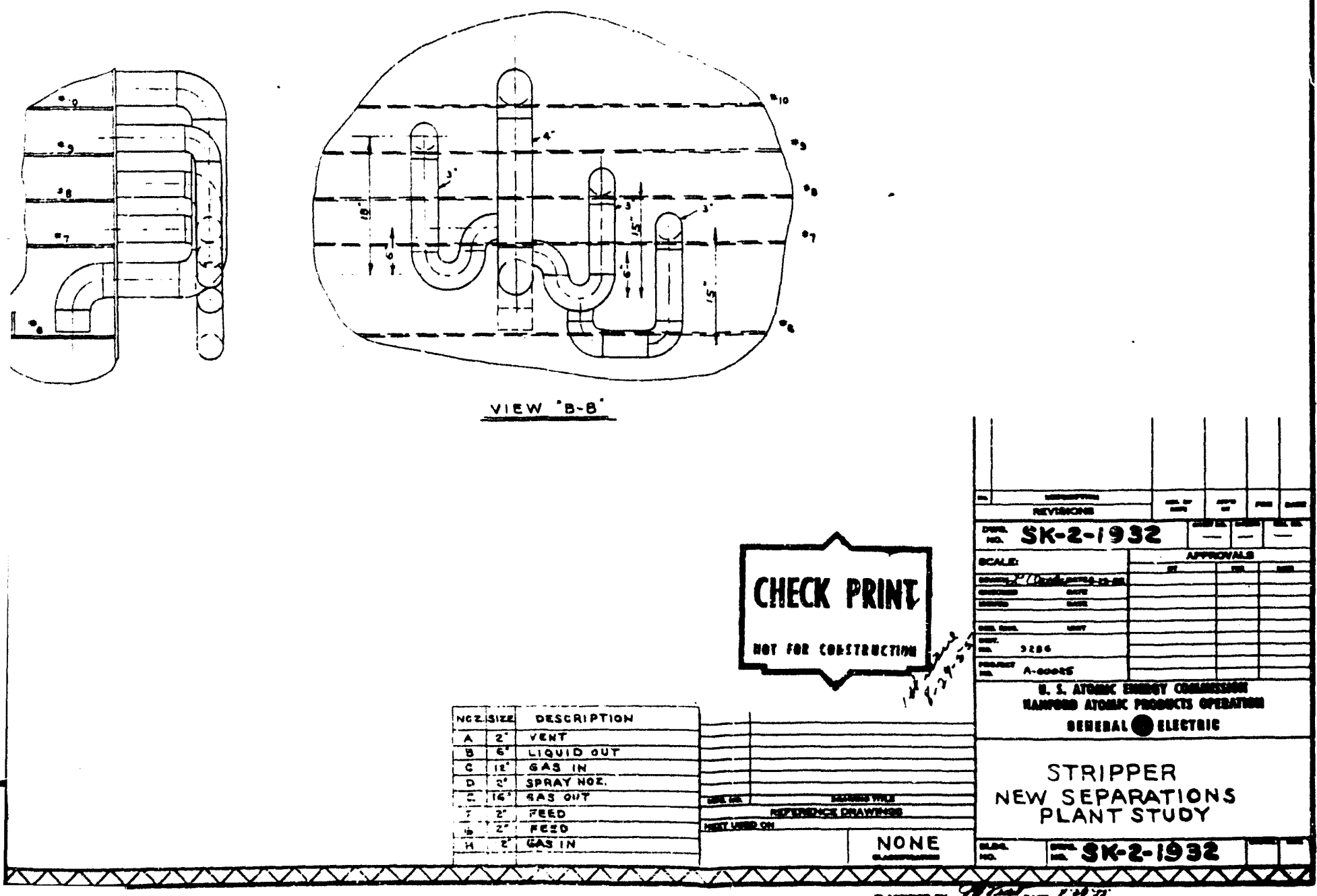


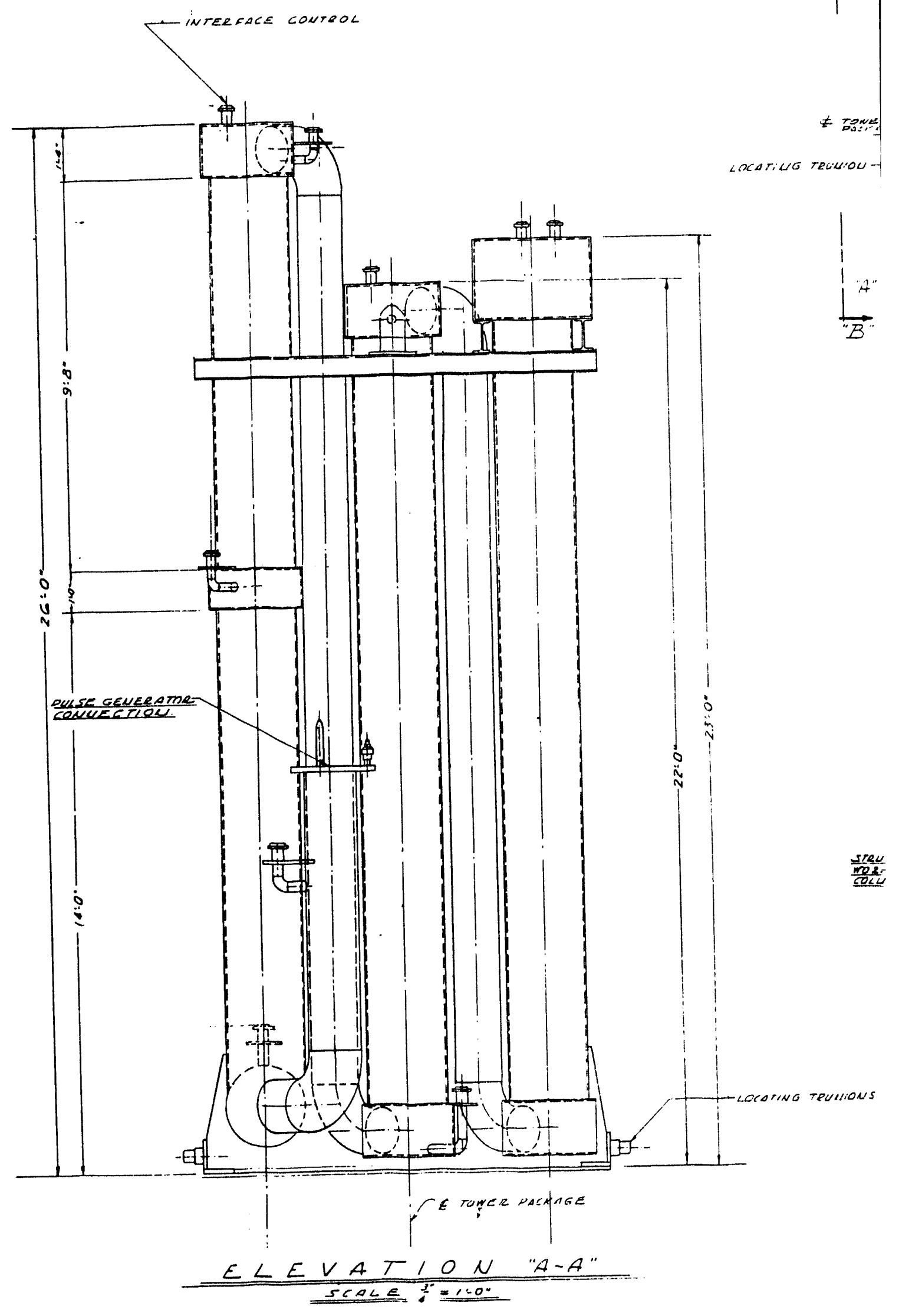




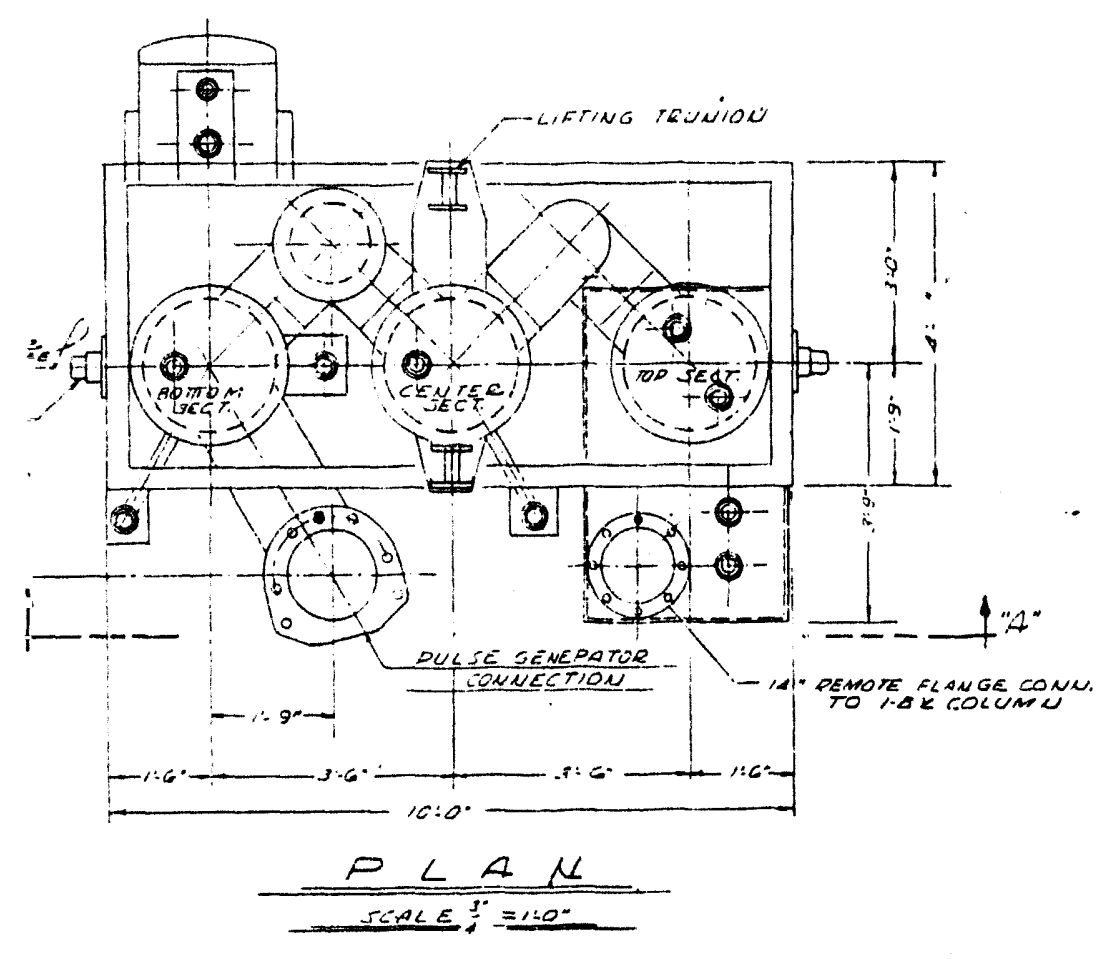

HiN 33881

PACE 74

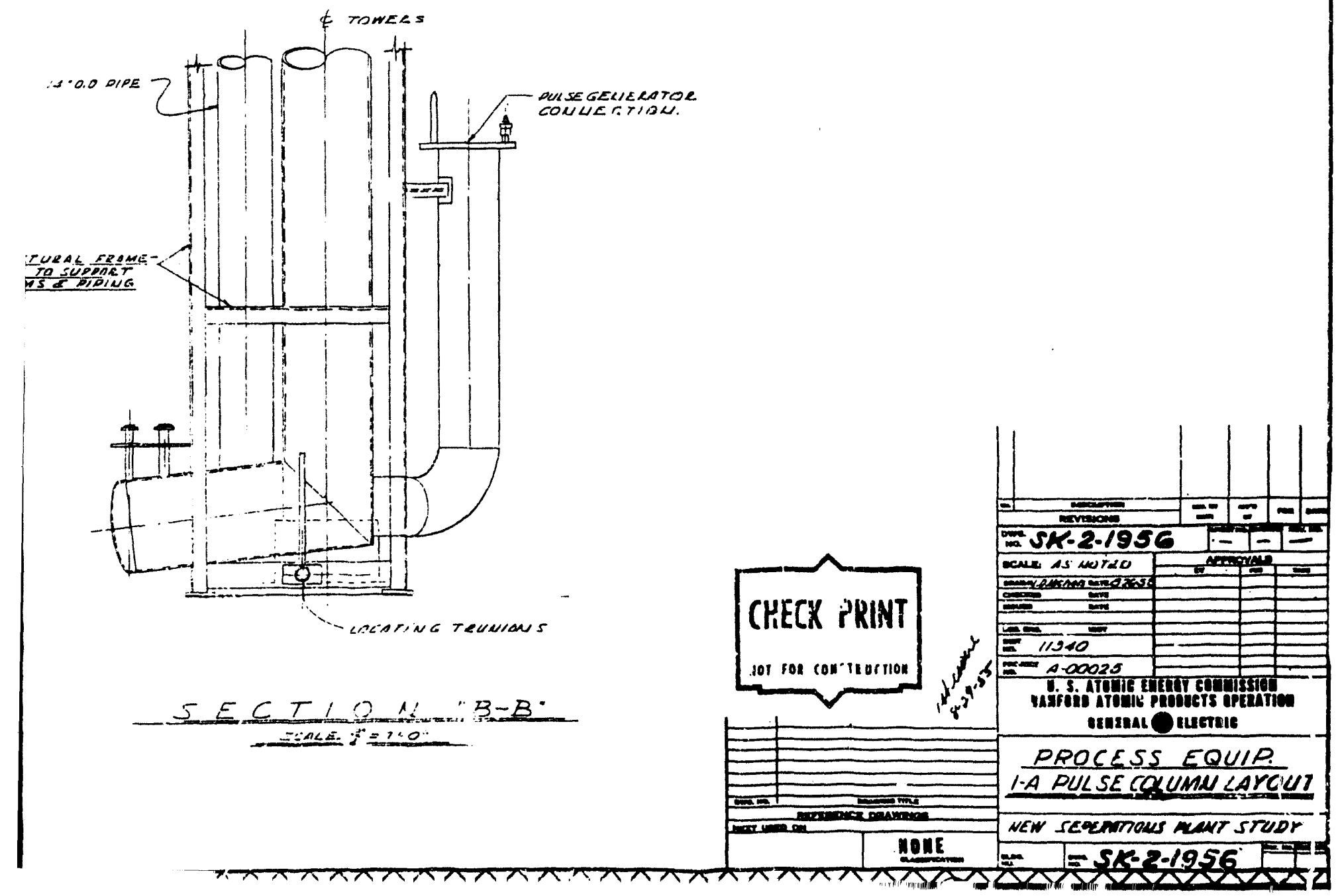



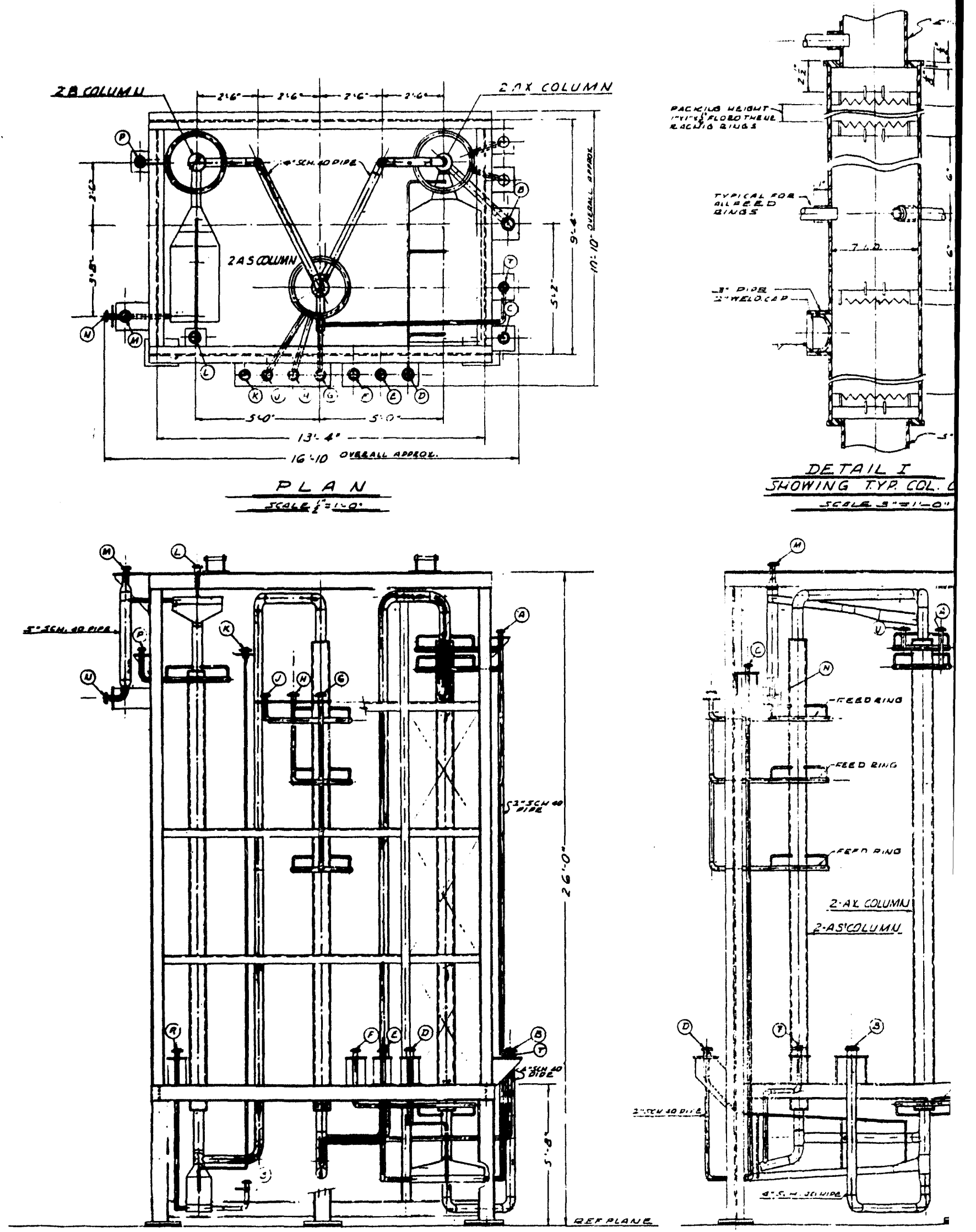

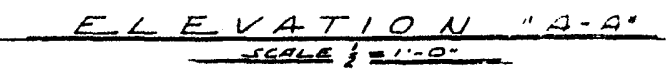

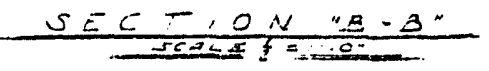




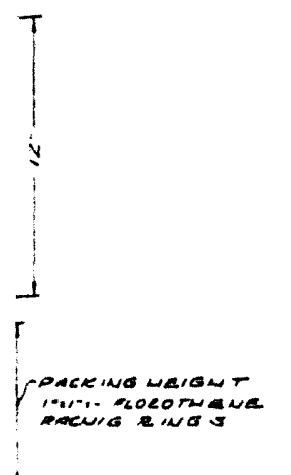

VOZRLE IOENTIFICATION

\begin{tabular}{|c|c|}
\hline \multicolumn{2}{|c|}{ VOZZLE IDENTIFICATION } \\
\hline $402: \ldots$ & Fucrion \\
\hline 2. & 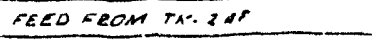 \\
\hline 3 & OULSE GENAR OTRE COLNACTOW \\
\hline$E$ & SETOUT TO I. AR TE. \\
\hline D & :AR COL I I COUTROL \& PNESS \\
\hline$\underline{E}$ & TOACIO STRIDOER \\
\hline 7 & FEOM DAENIC FEED TANK \\
\hline$G$ & 24 S:PUA \\
\hline 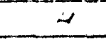 & zas (acternate sclua) \\
\hline$j$ & 2 AS (ALTERnATE SCRUAS) \\
\hline$\kappa$ & $2 B$ COL DOESS. \\
\hline$L$ & WTER FACE COWTEOL \\
\hline$M$ & resse vent \\
\hline$\sim$ & ro cos $1 . a$ \\
\hline 2 & $2 . B<F \in E D$ \\
\hline$R$ & TO 2.45 $=0 L U M N$ (VIA DUMA) \\
\hline 5 & DO 2.8 RECEIVER \\
\hline & $\dot{.}$ \\
\hline
\end{tabular}

QNSTRUCTION.
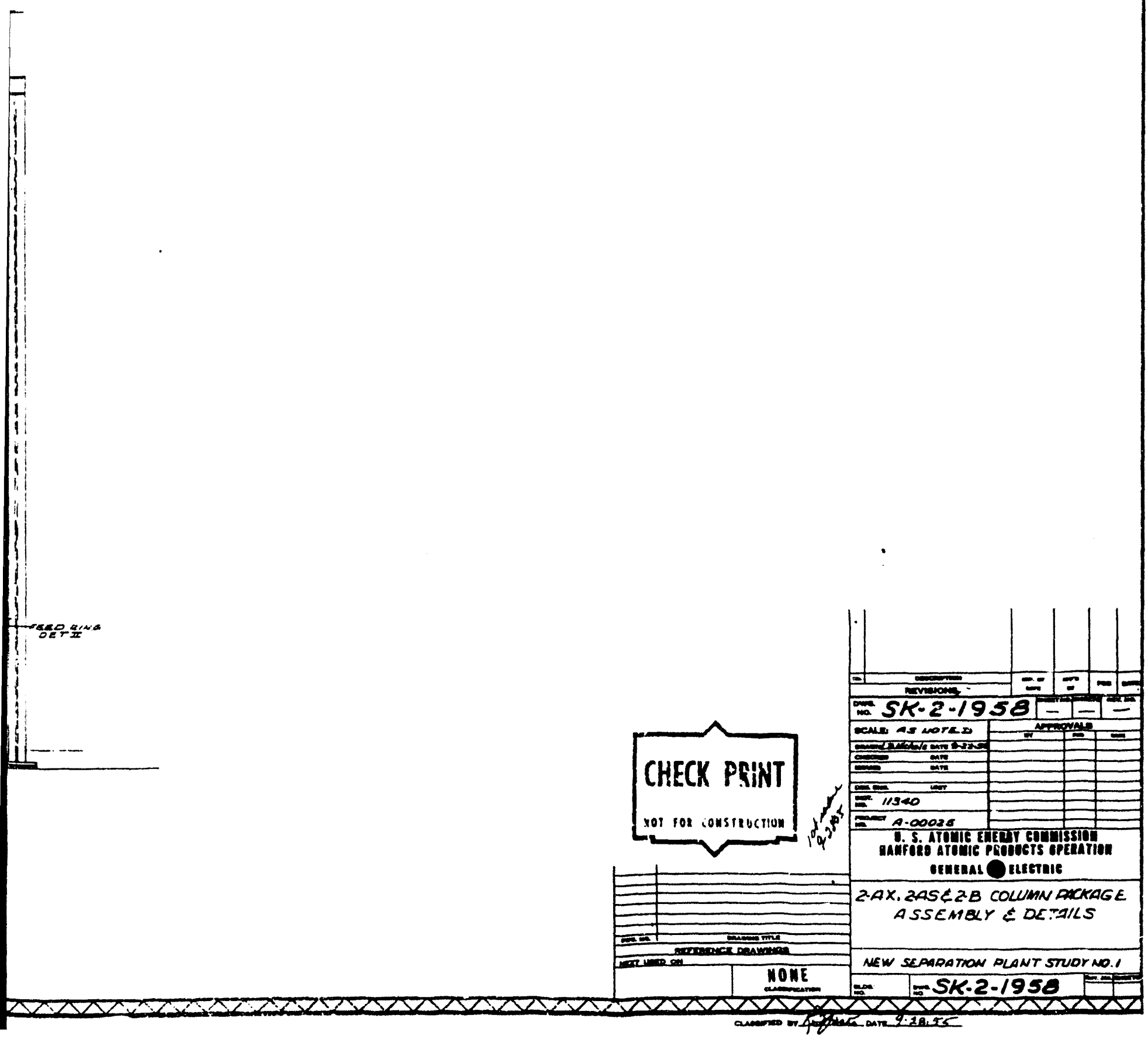

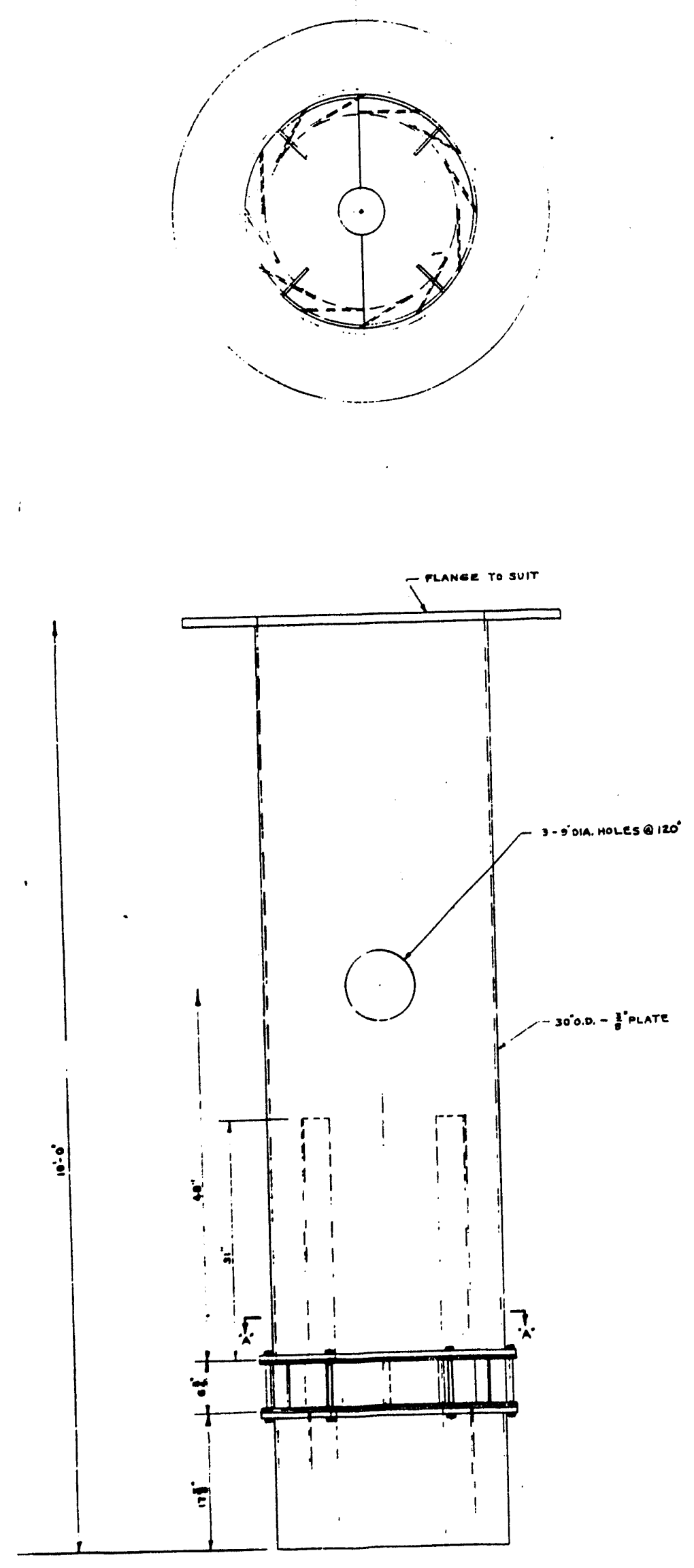


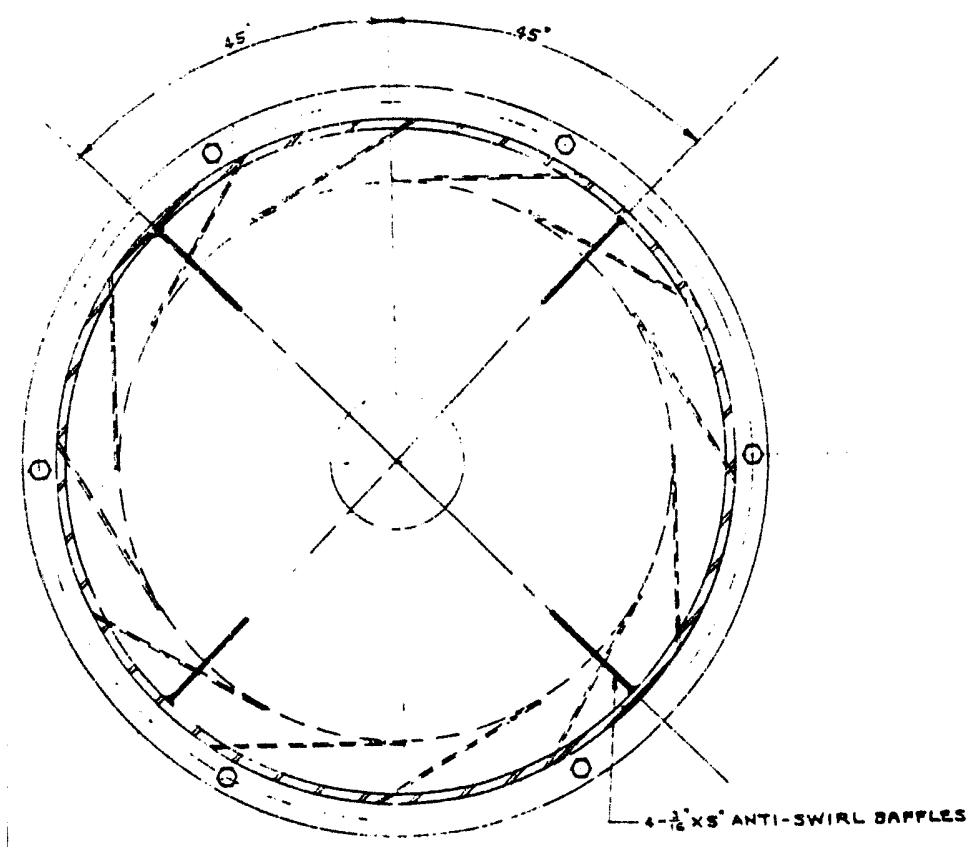

HW 38881

FAGE 16

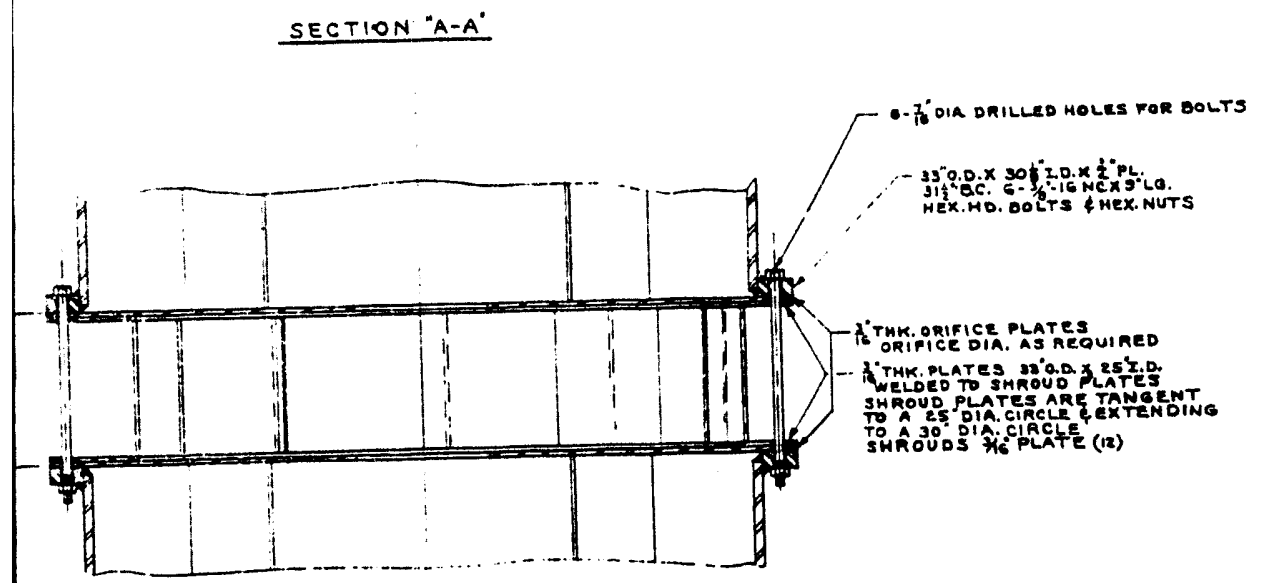

ELEVATION

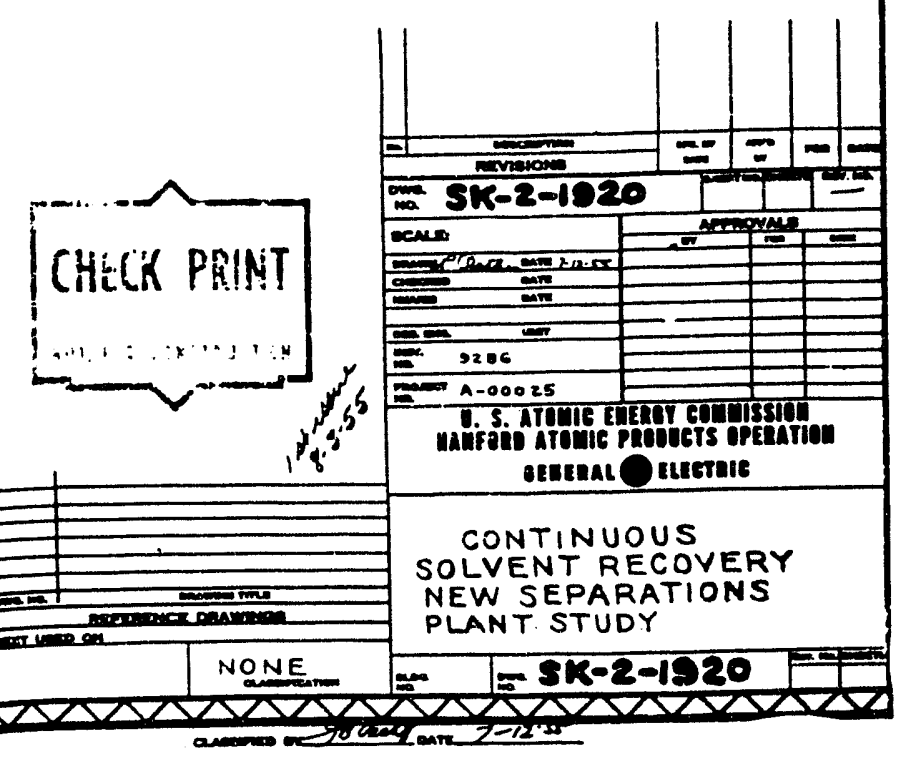




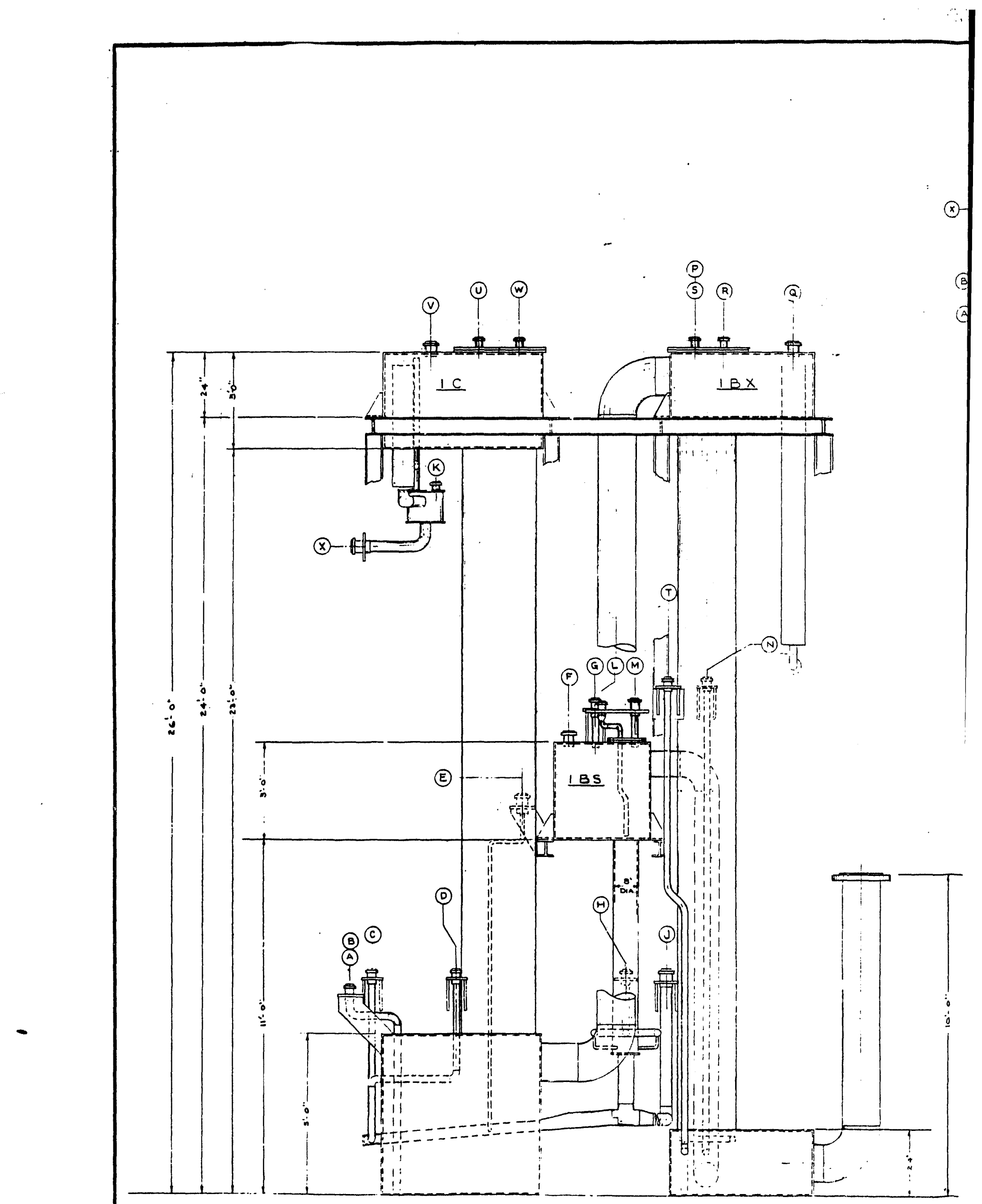



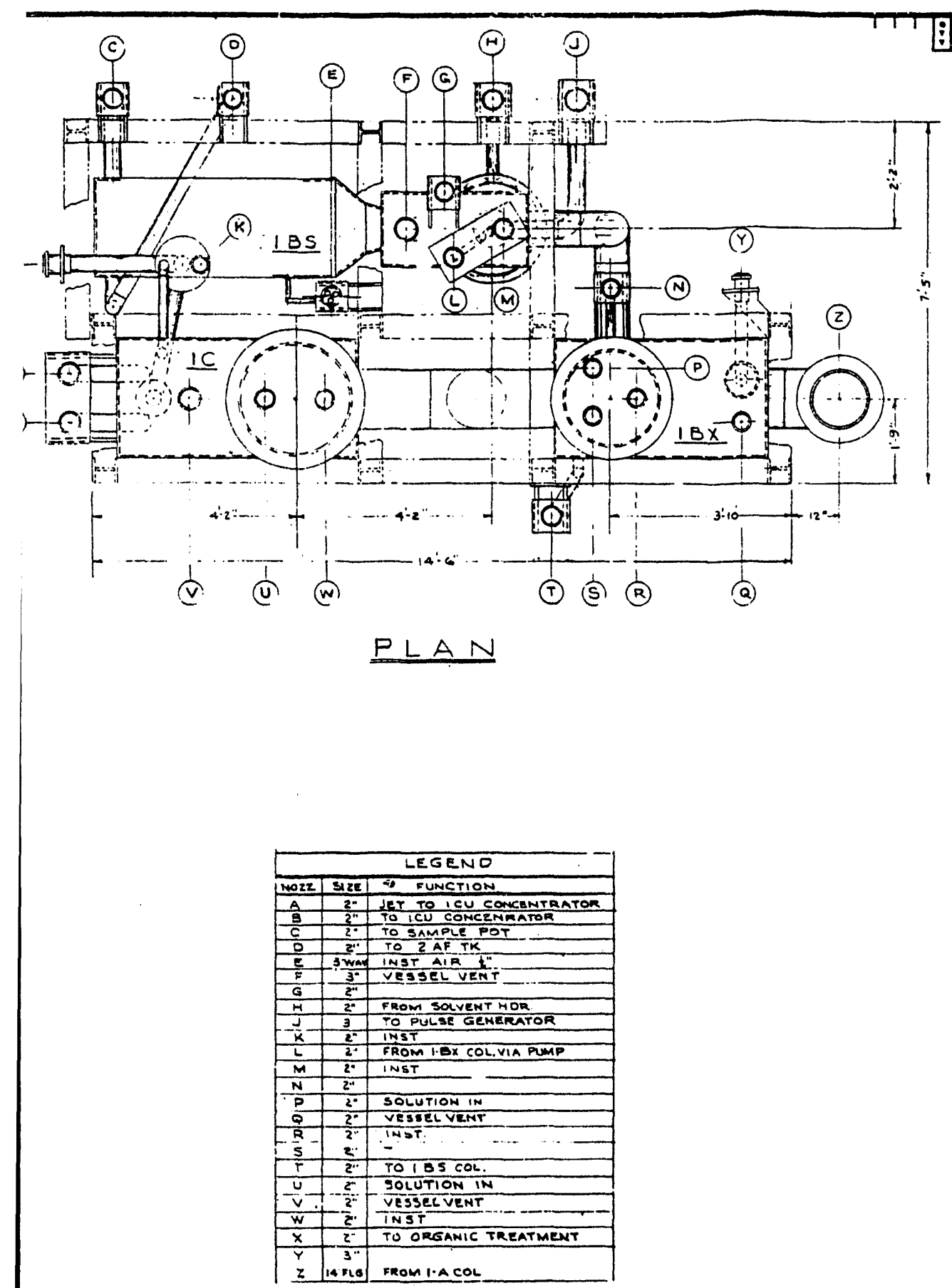

HW 38881

PAGE 11

\section{$P L A N$}




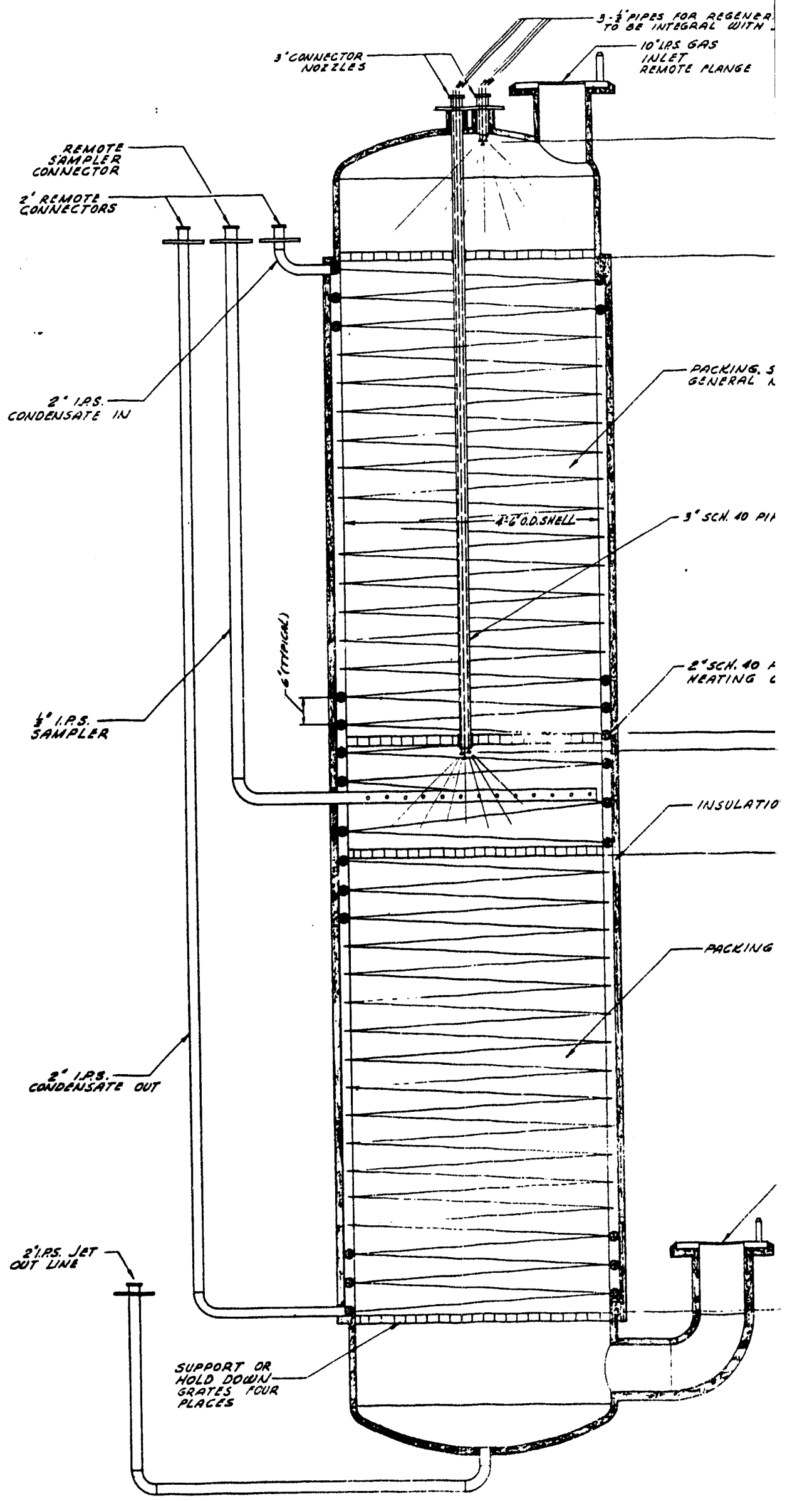




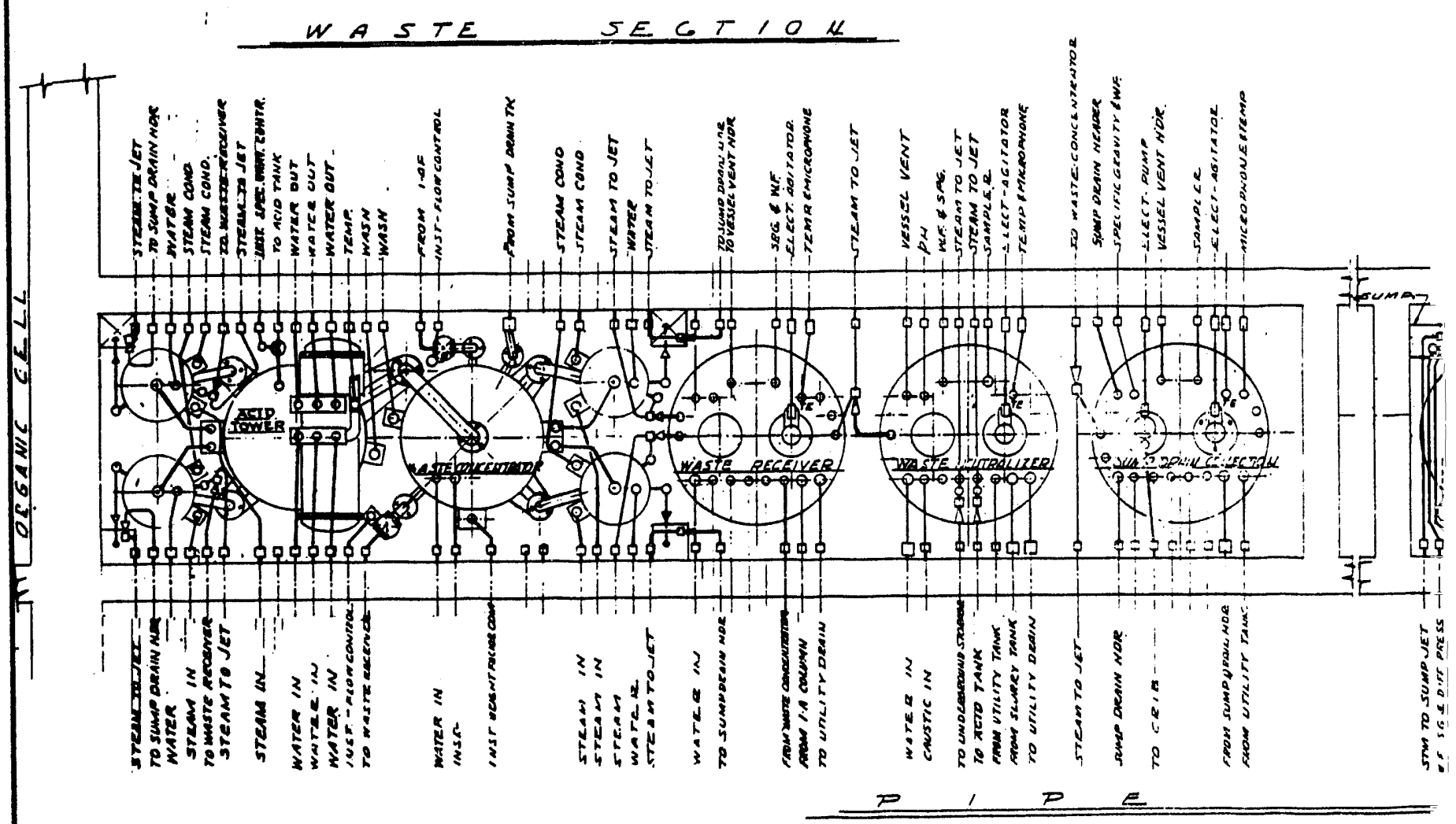




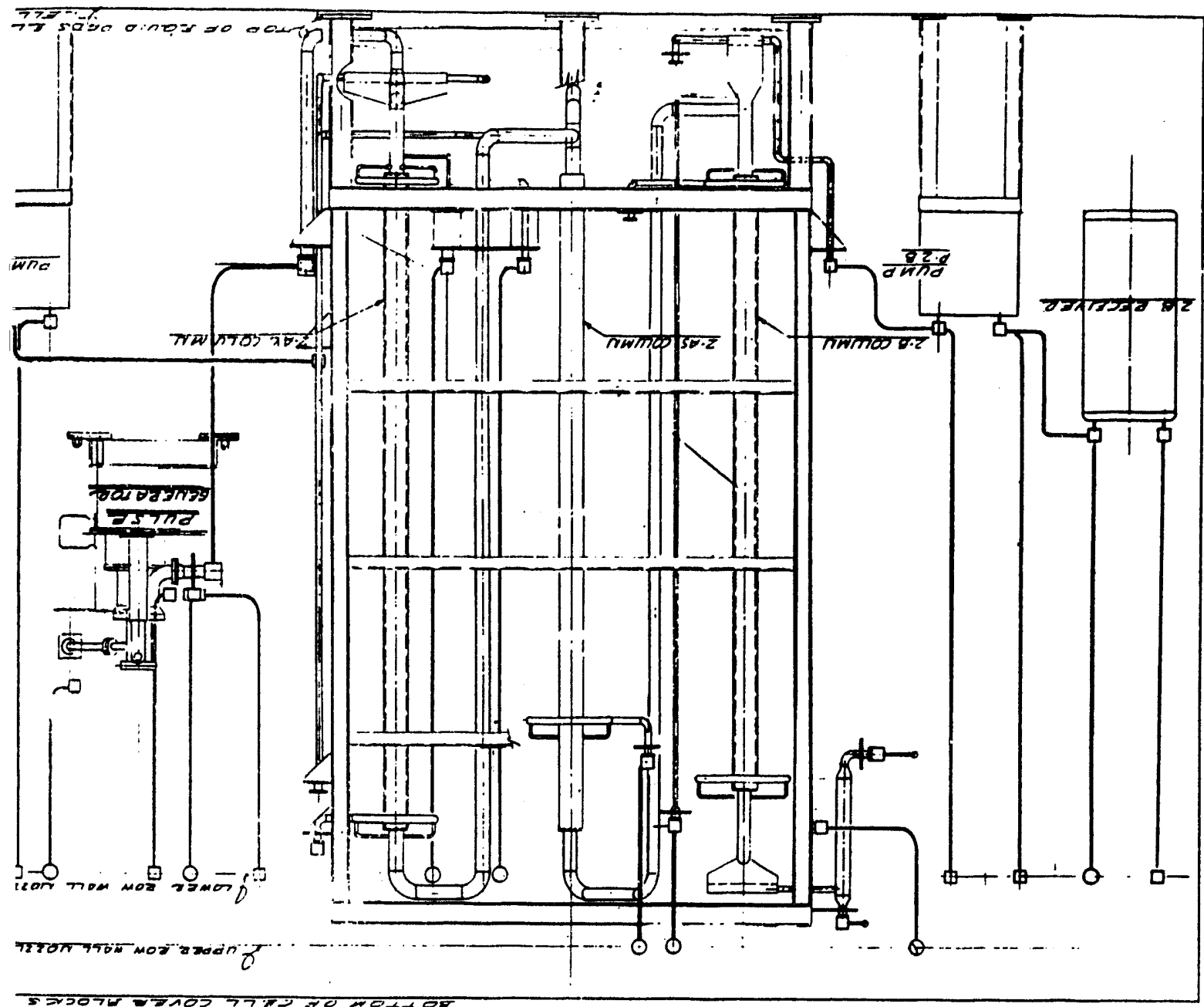

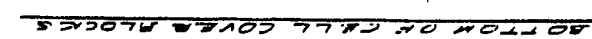

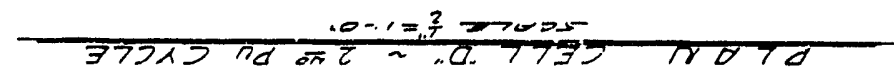

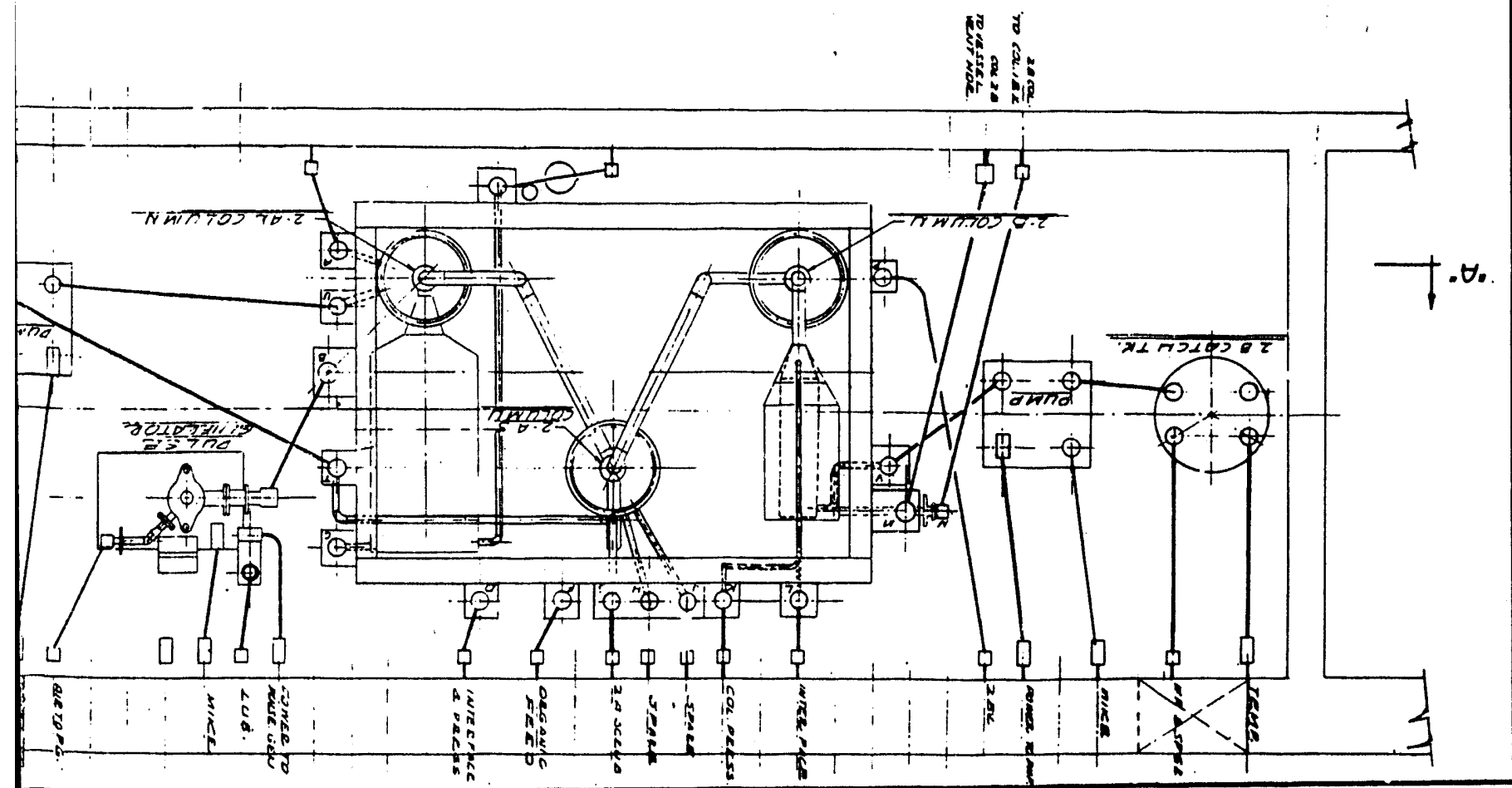




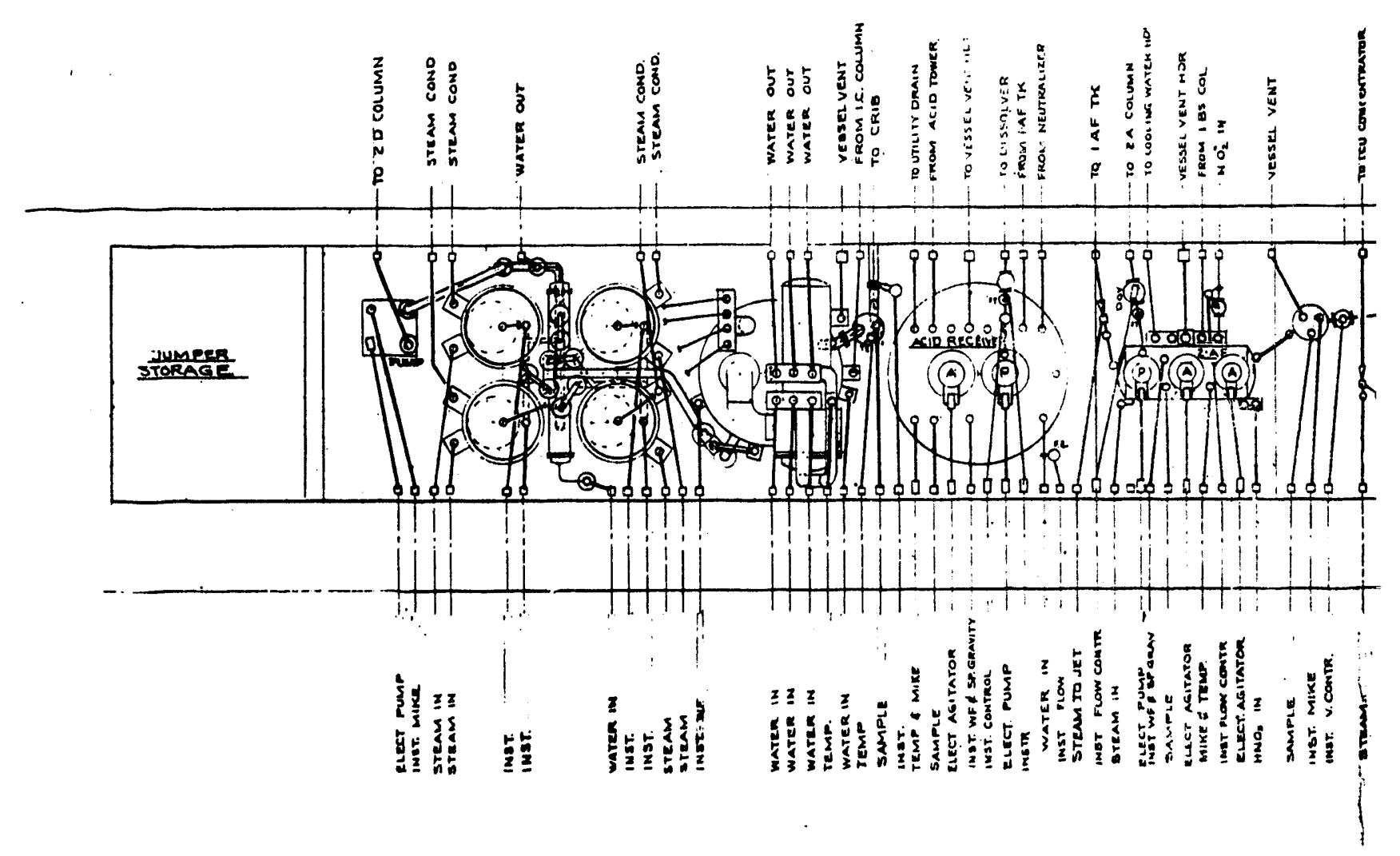





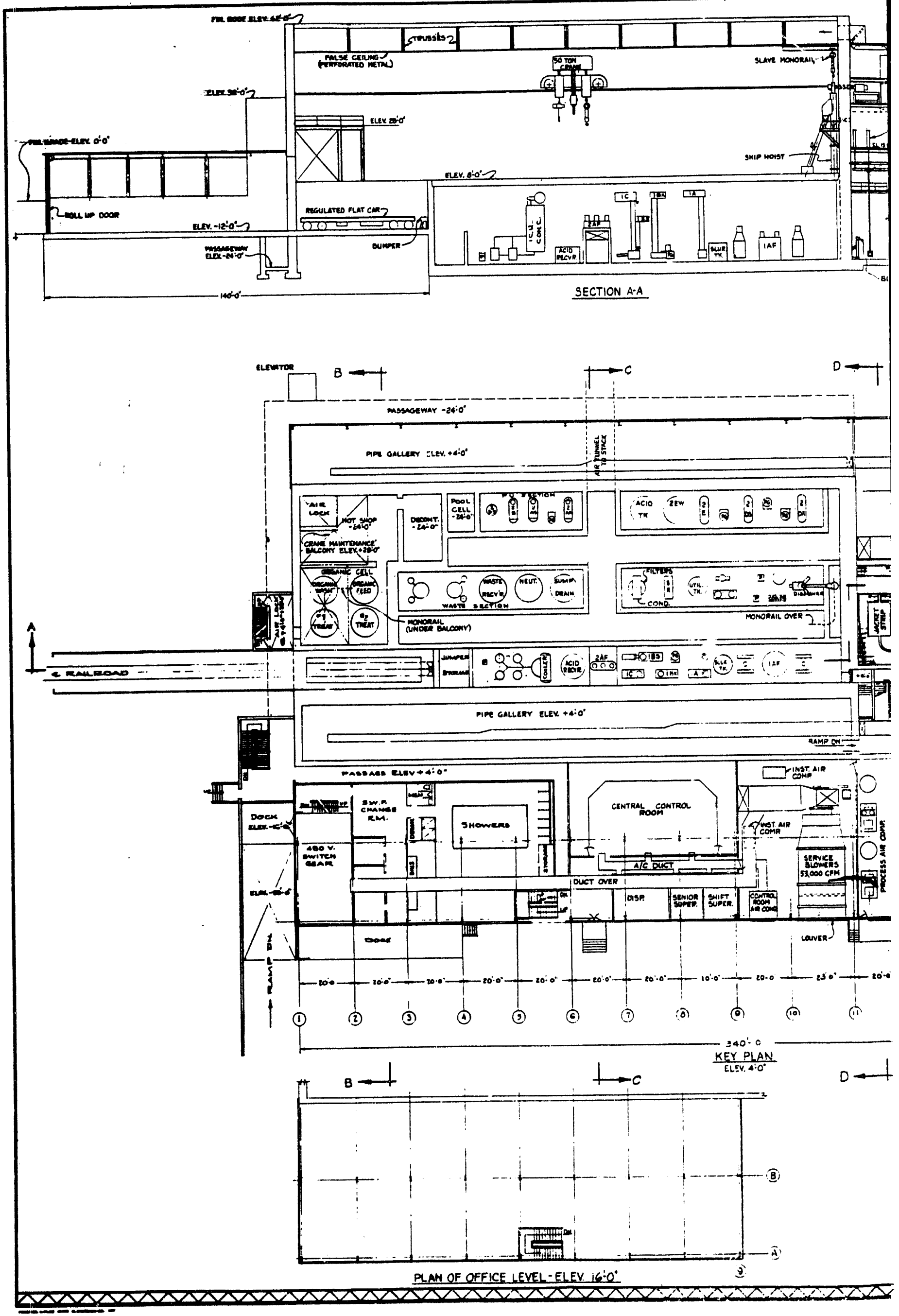


$\therefore \because 1$

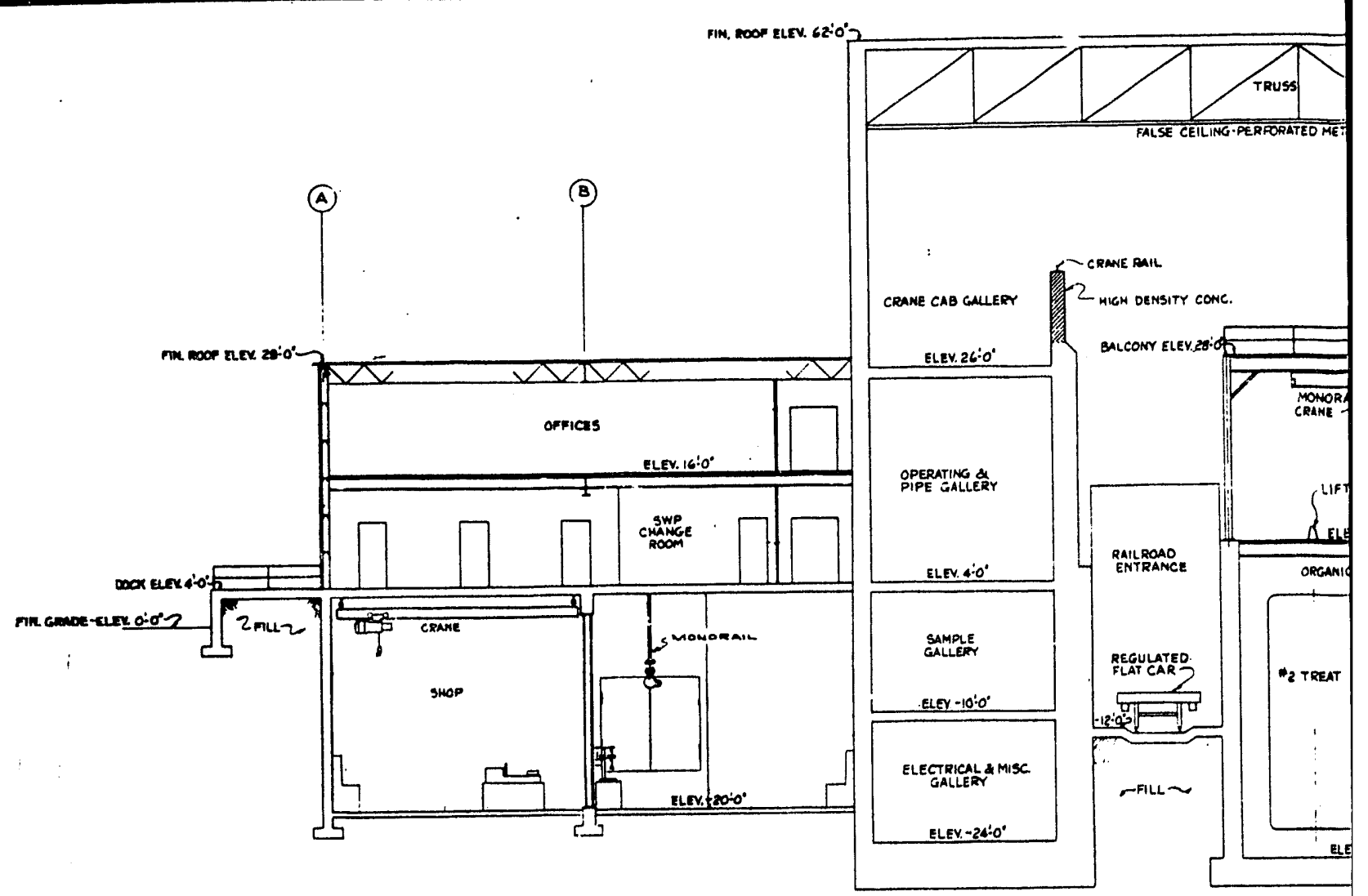

SECTION B.B

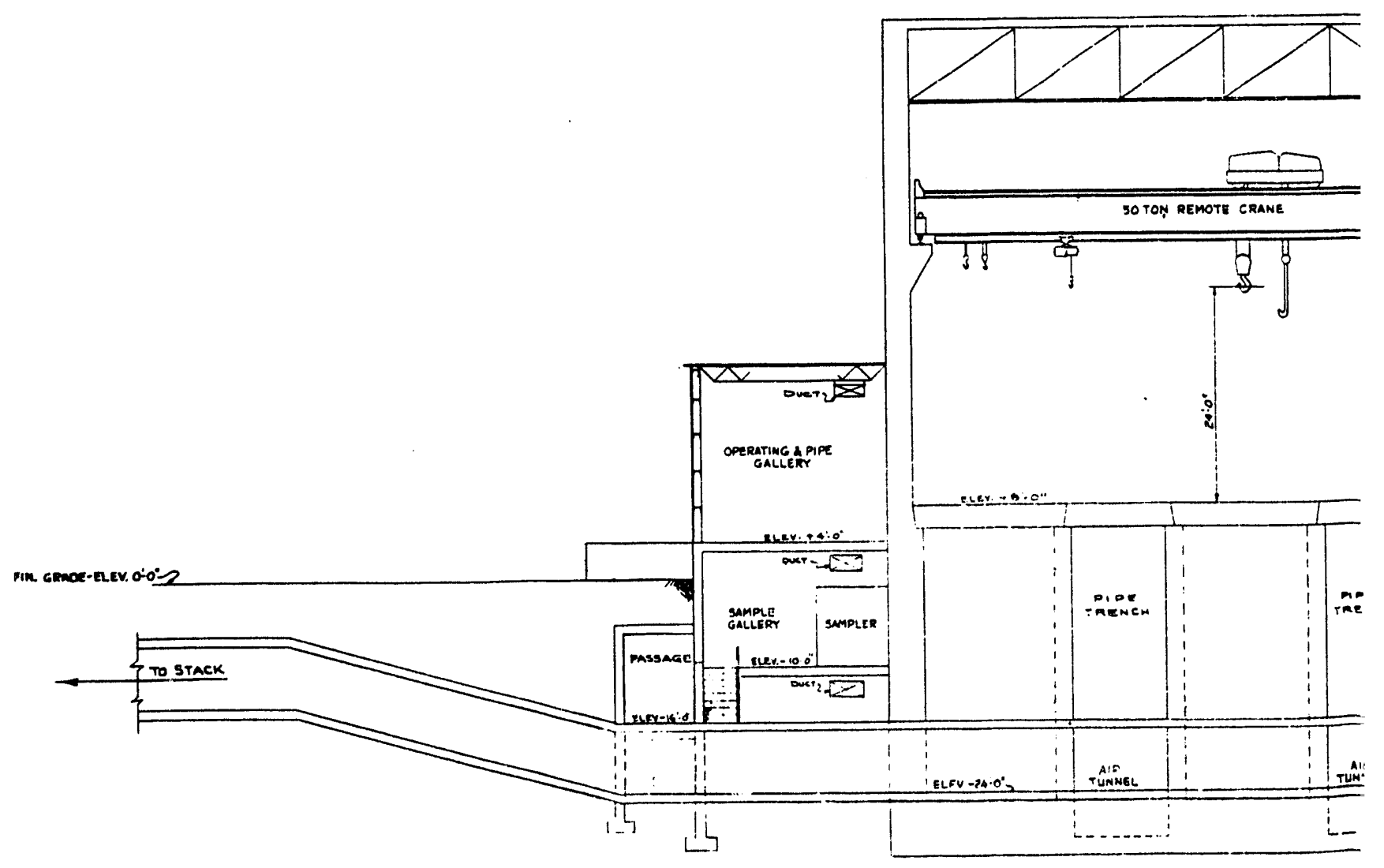

EECION C.C 


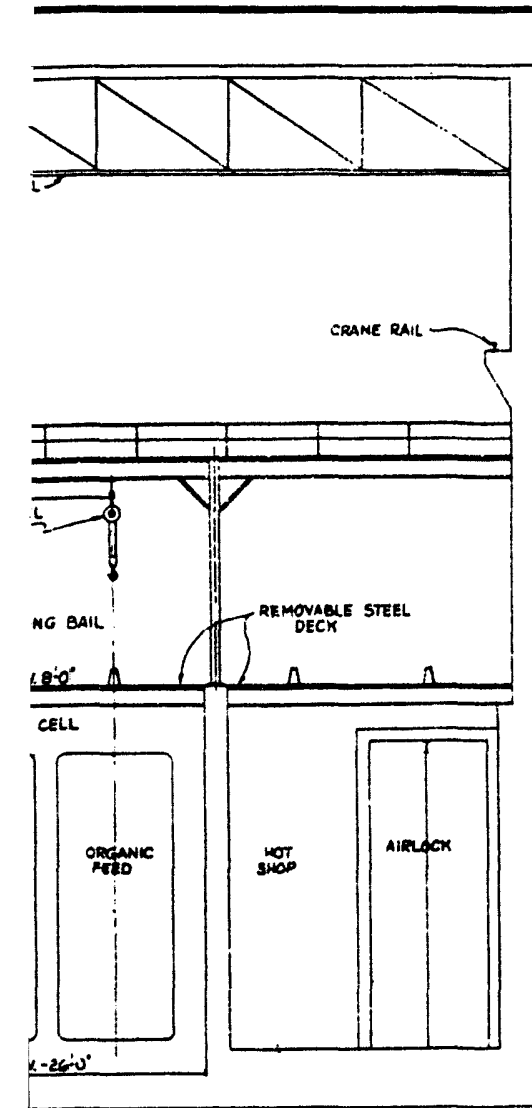

(ग)
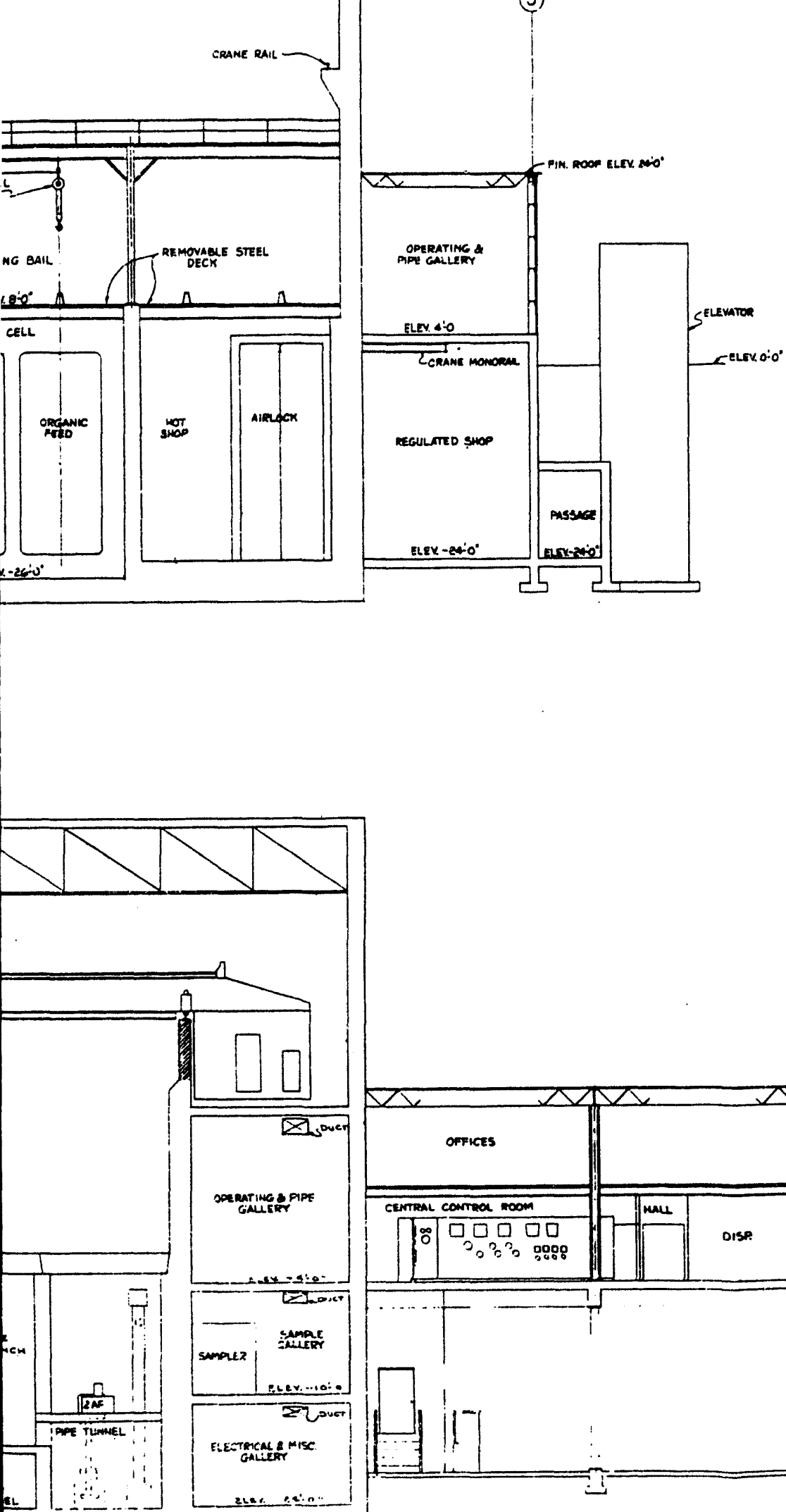
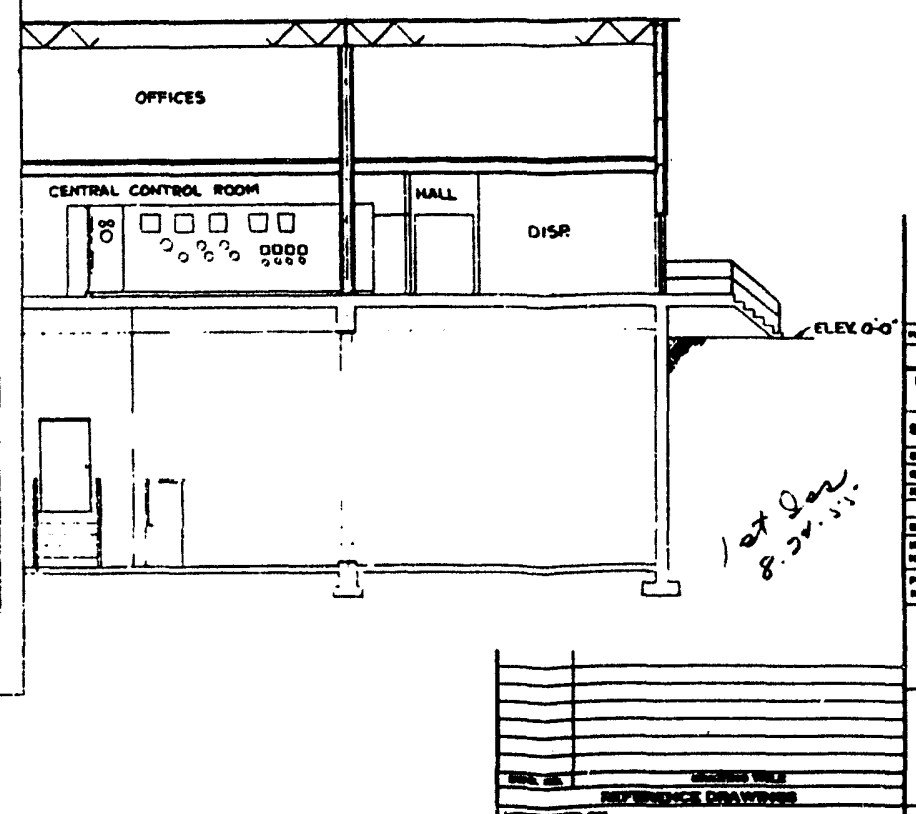

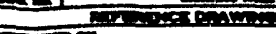

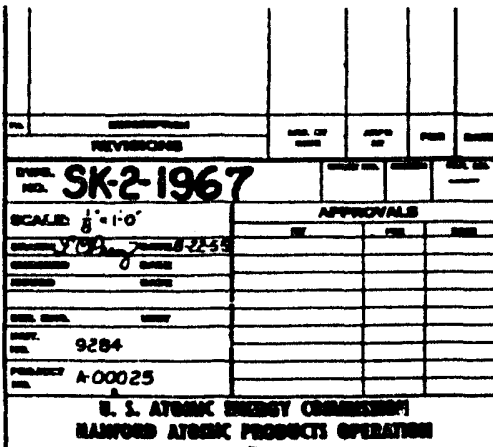
ezaknat tuetraie

\& PROCESS ARRANGEINENT SECTIONS 


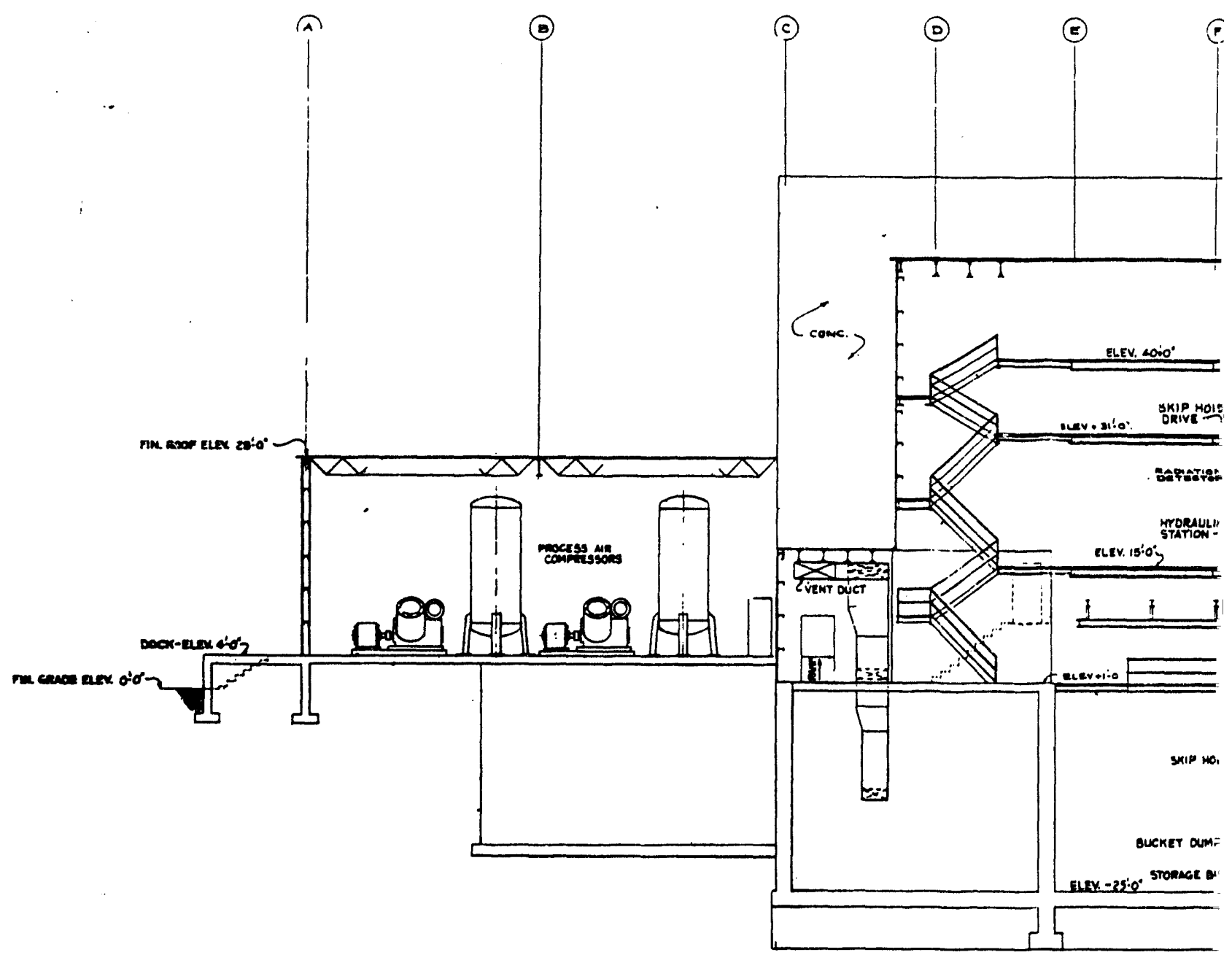

SECTION 


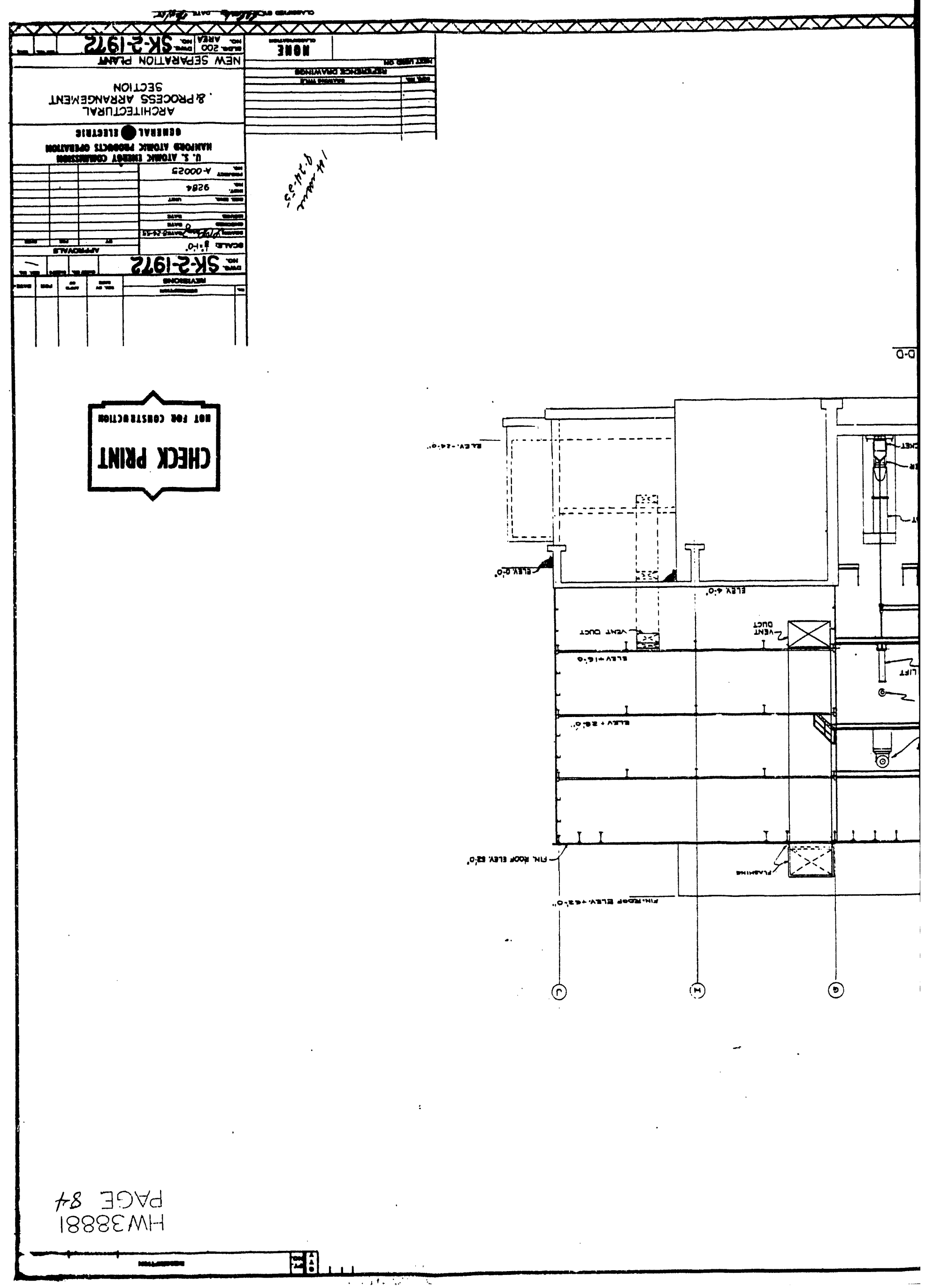




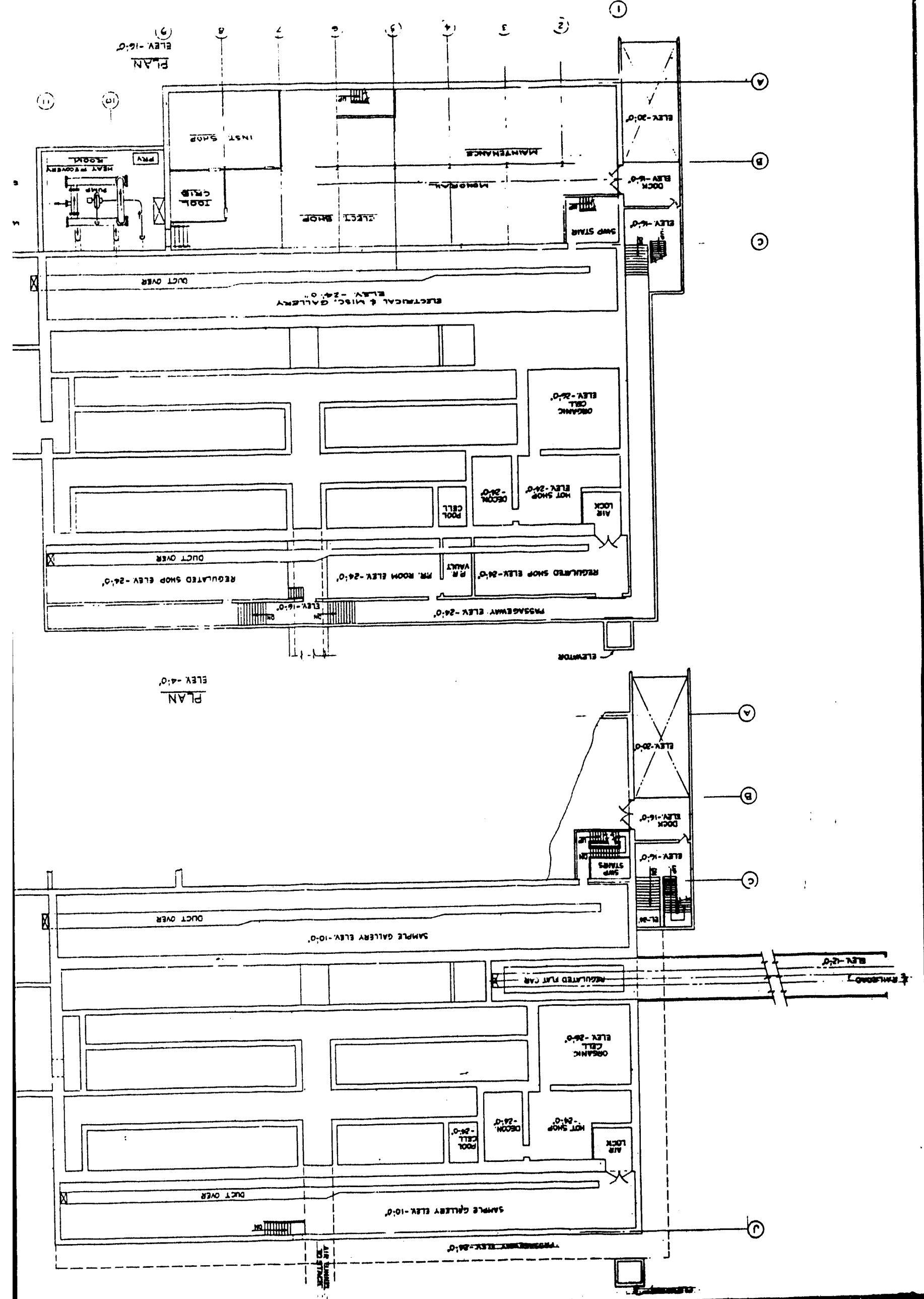




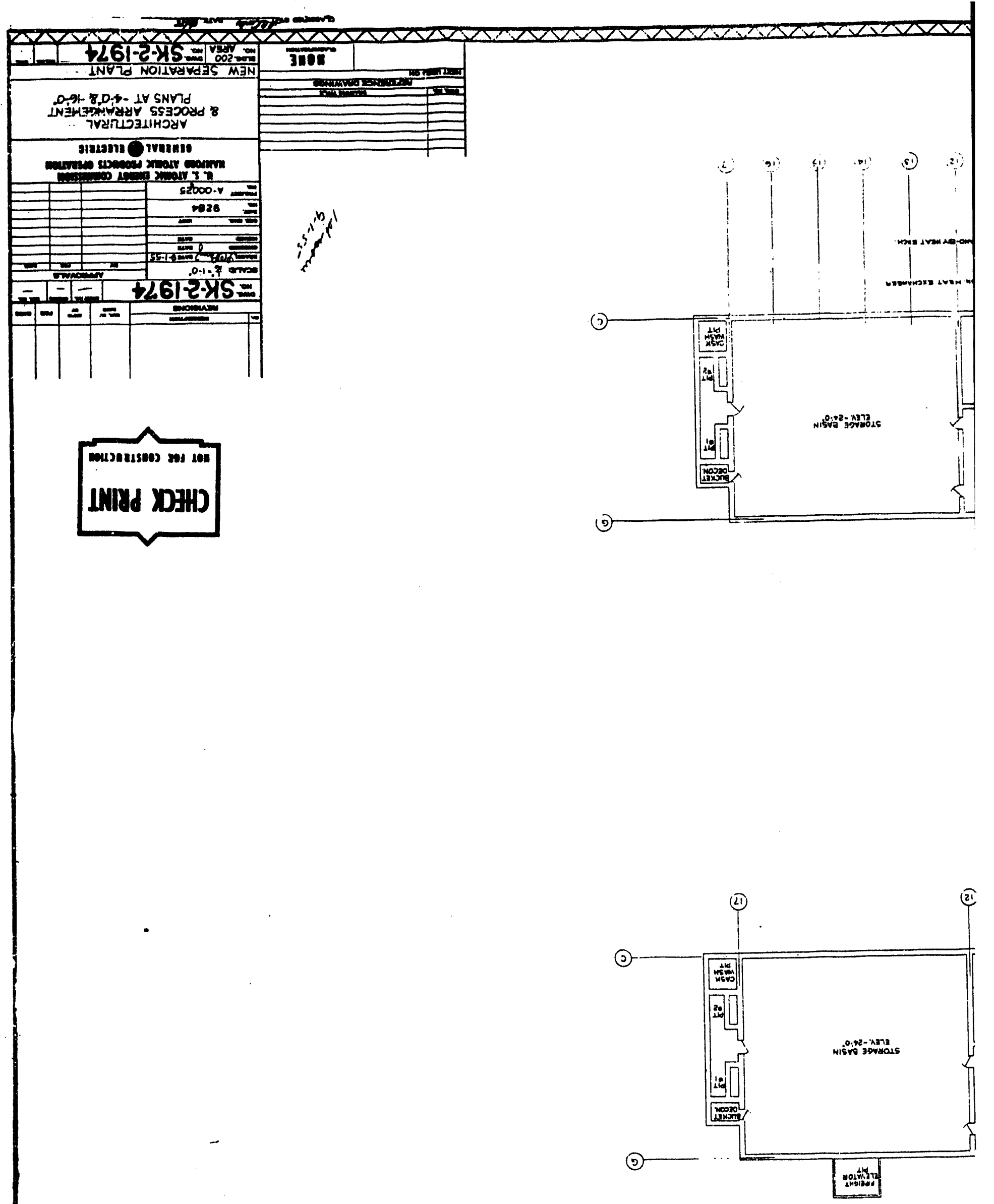

98 J9td 1888हMH 


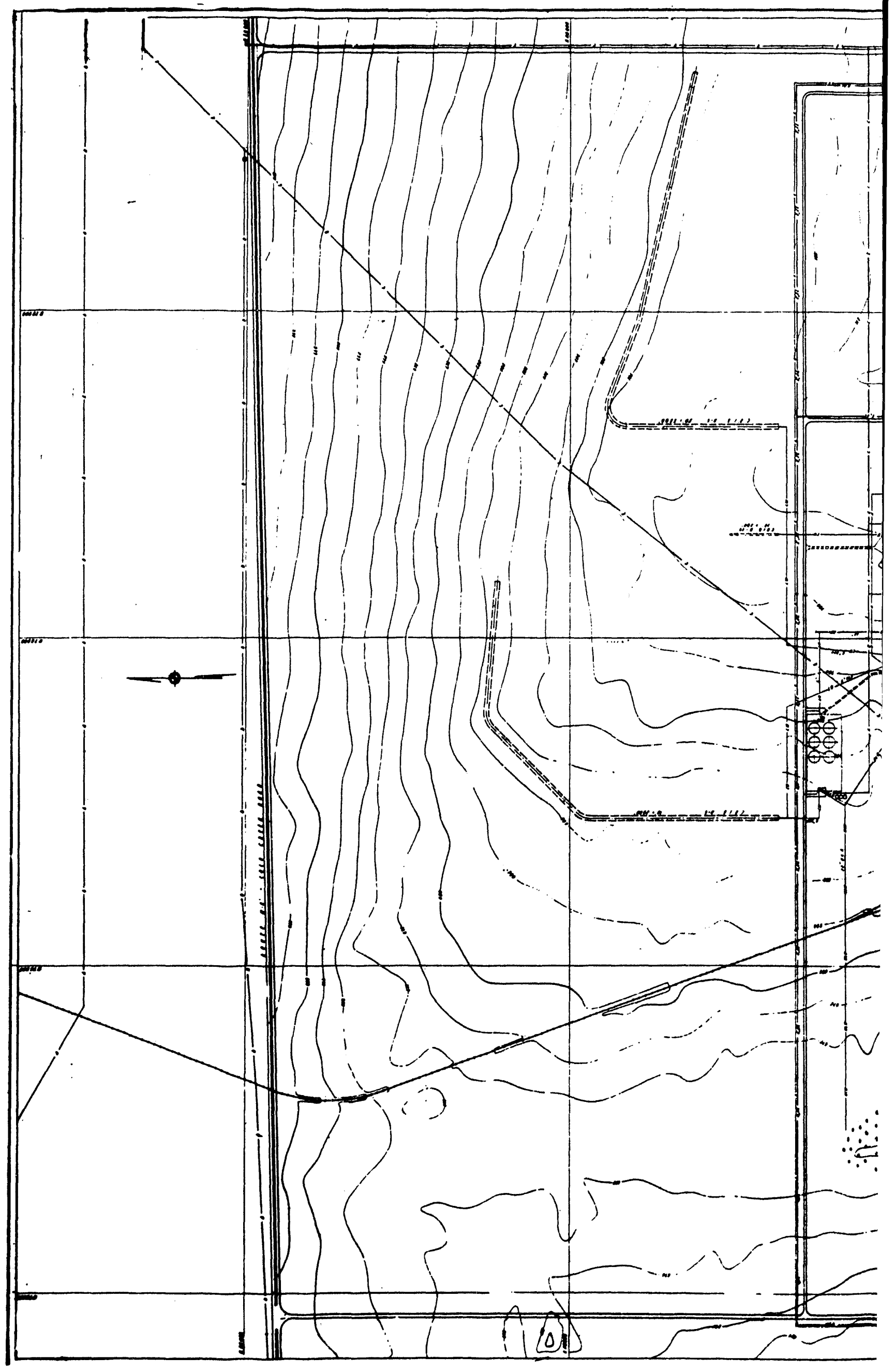


$H W-33881$

PAGE - 86

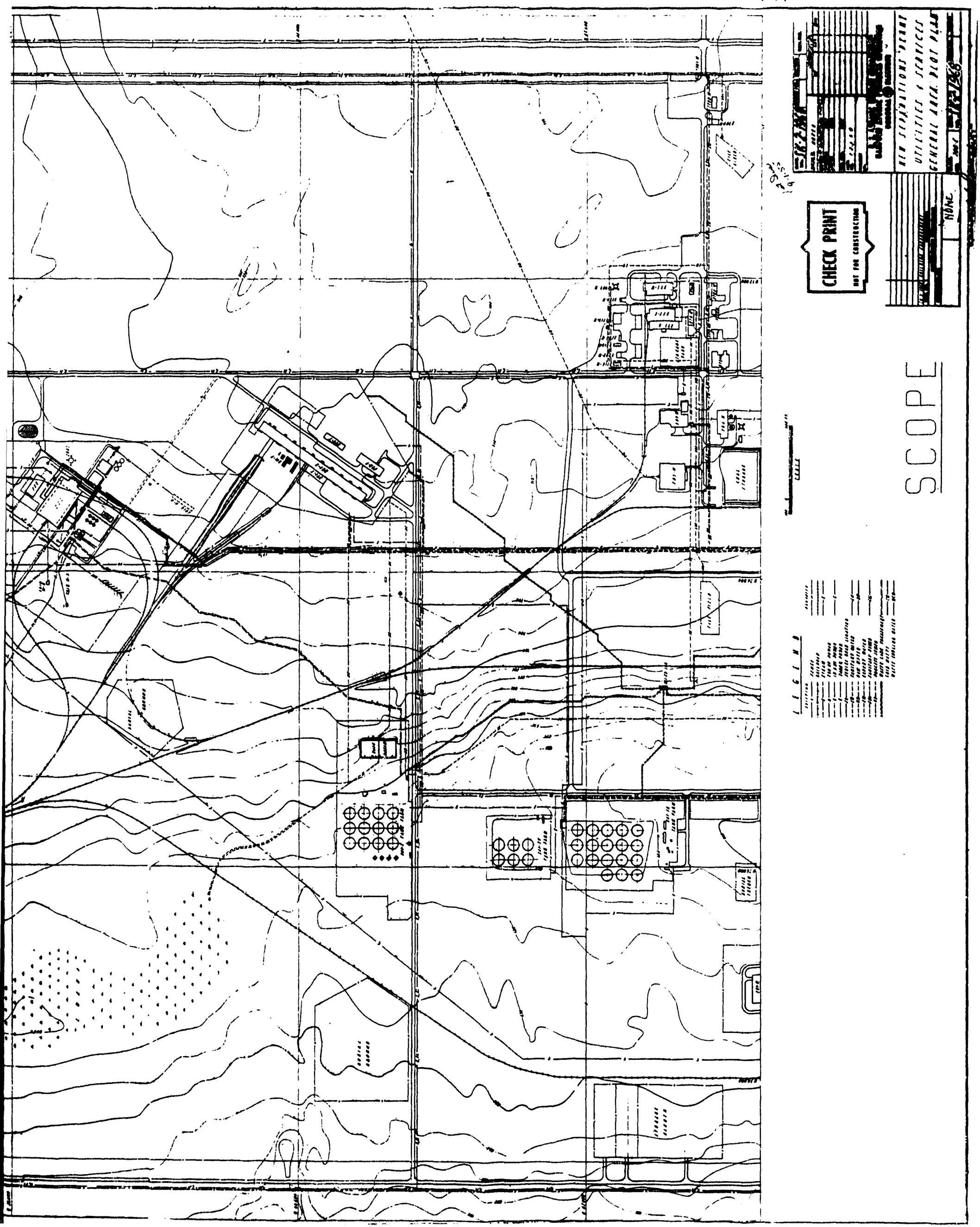




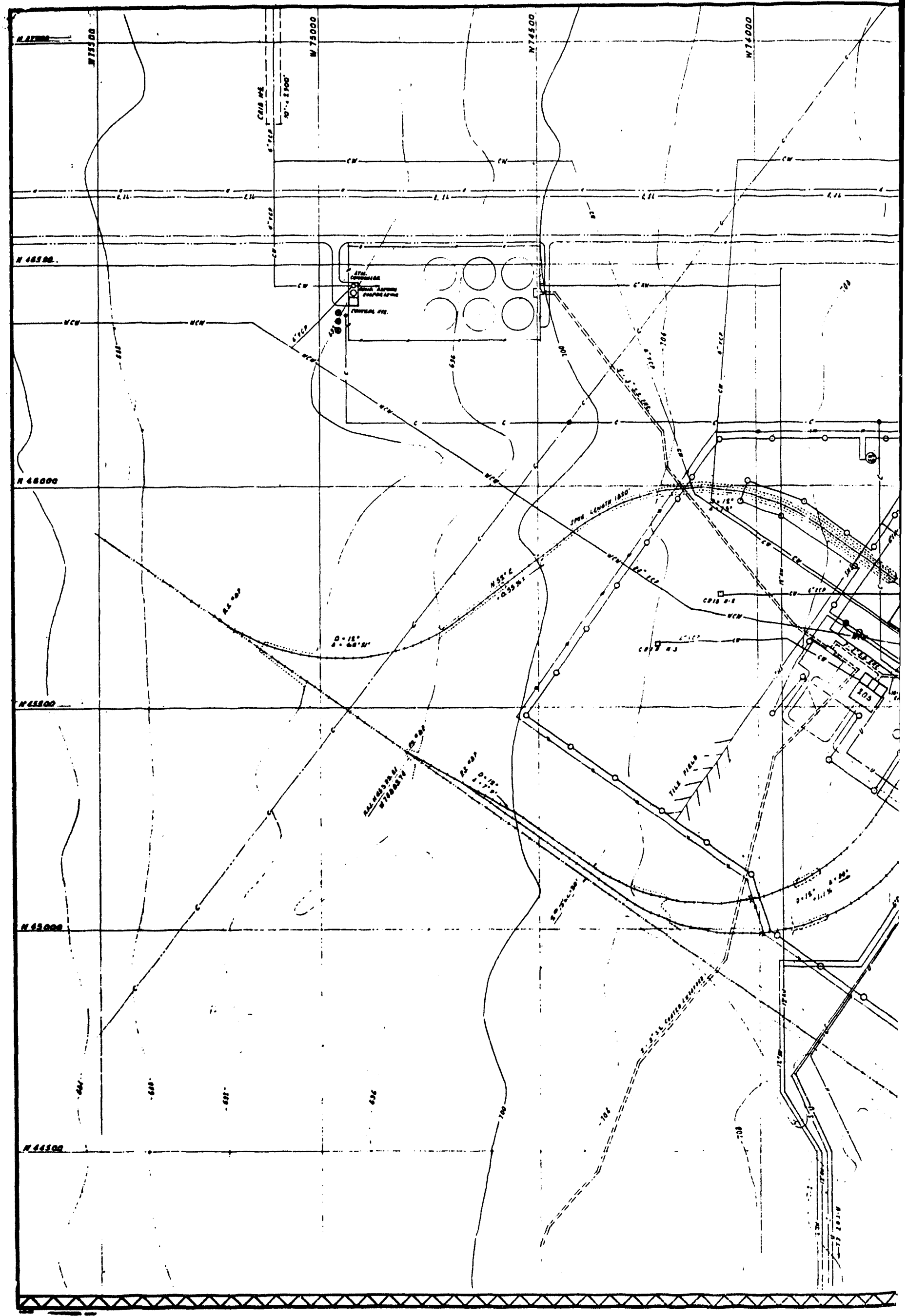




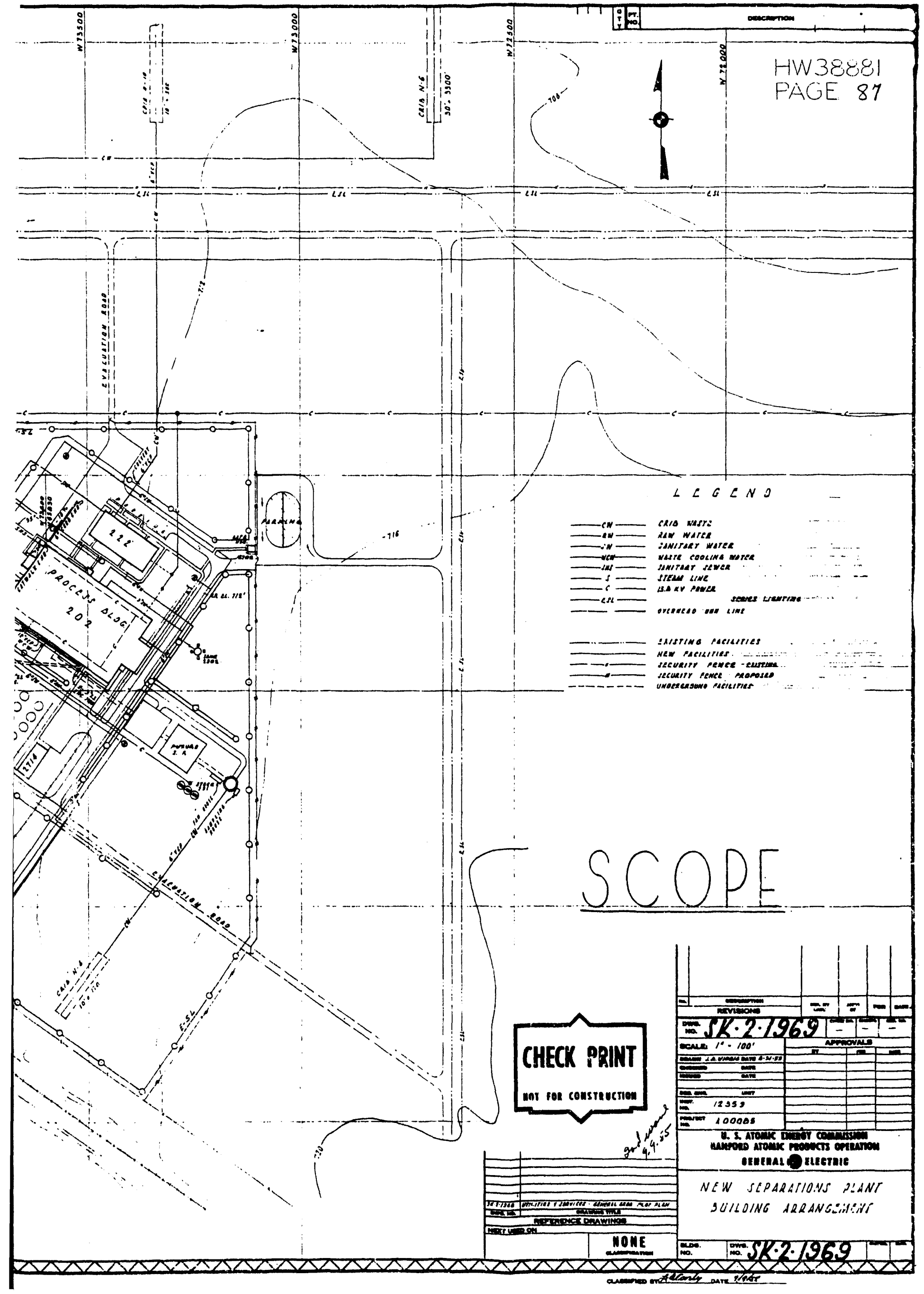



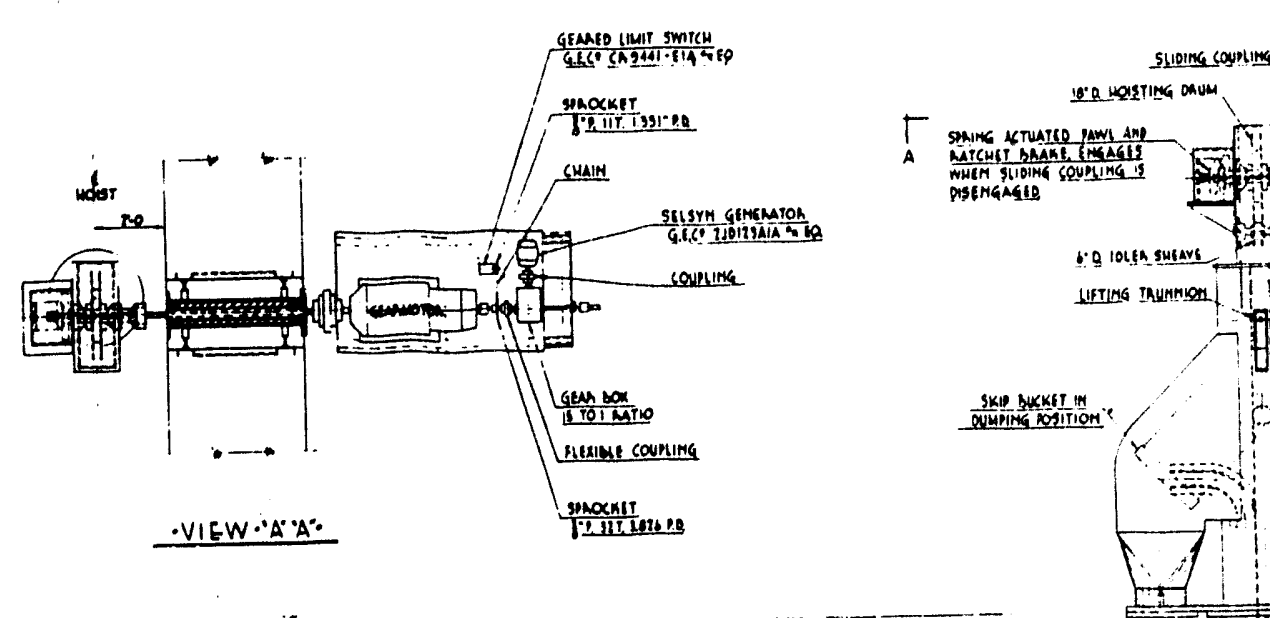

- Operation. Moteg.

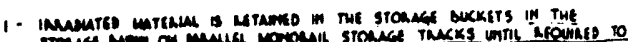

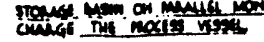

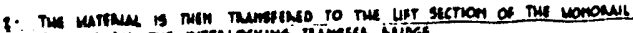

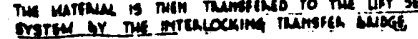

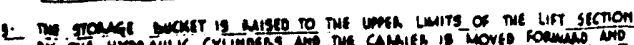

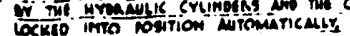

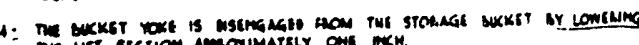

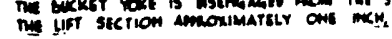

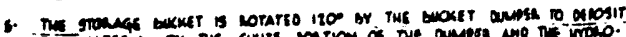

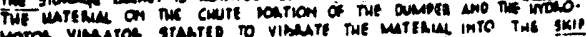
Eroptim

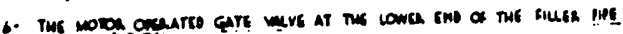
intion

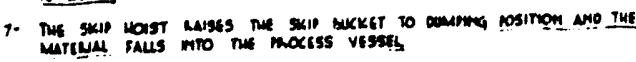

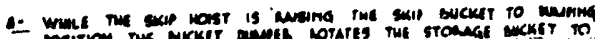

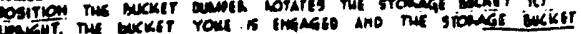
Annime io me srowal pis

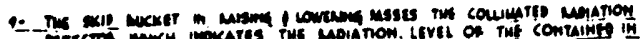

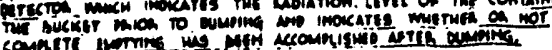

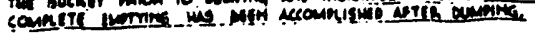

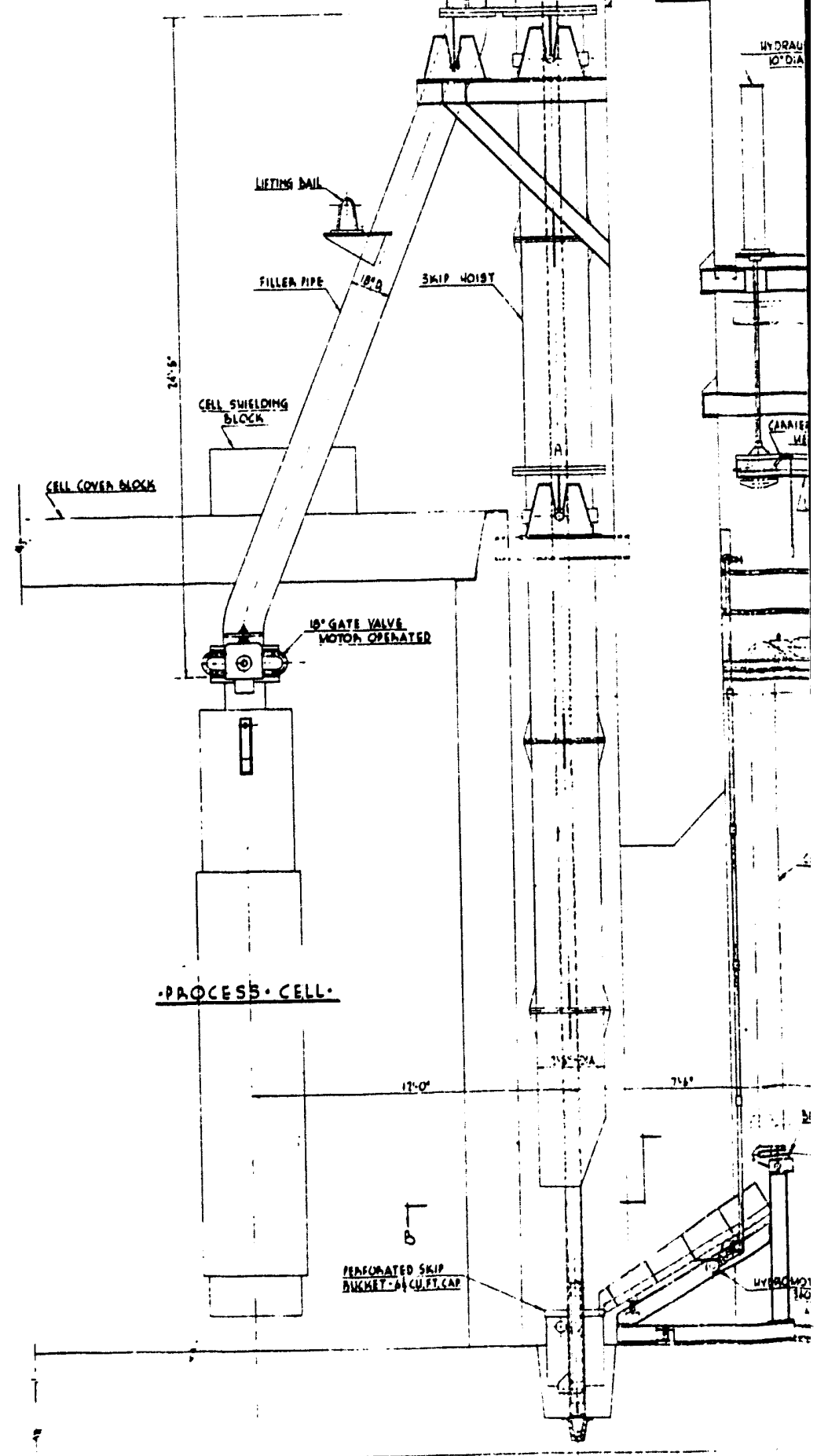



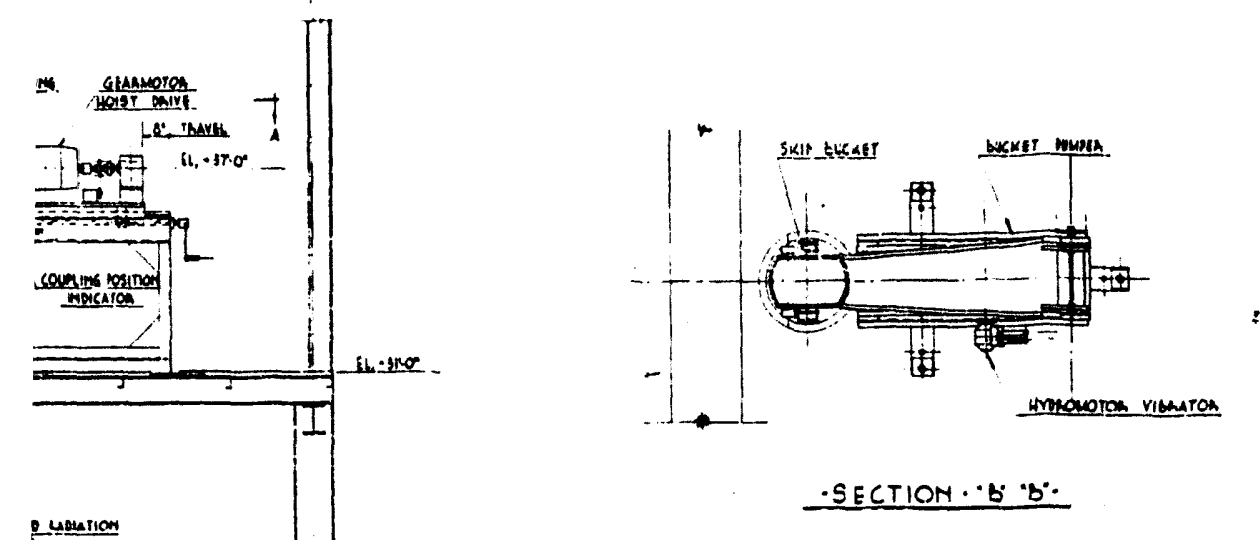

Ouserion
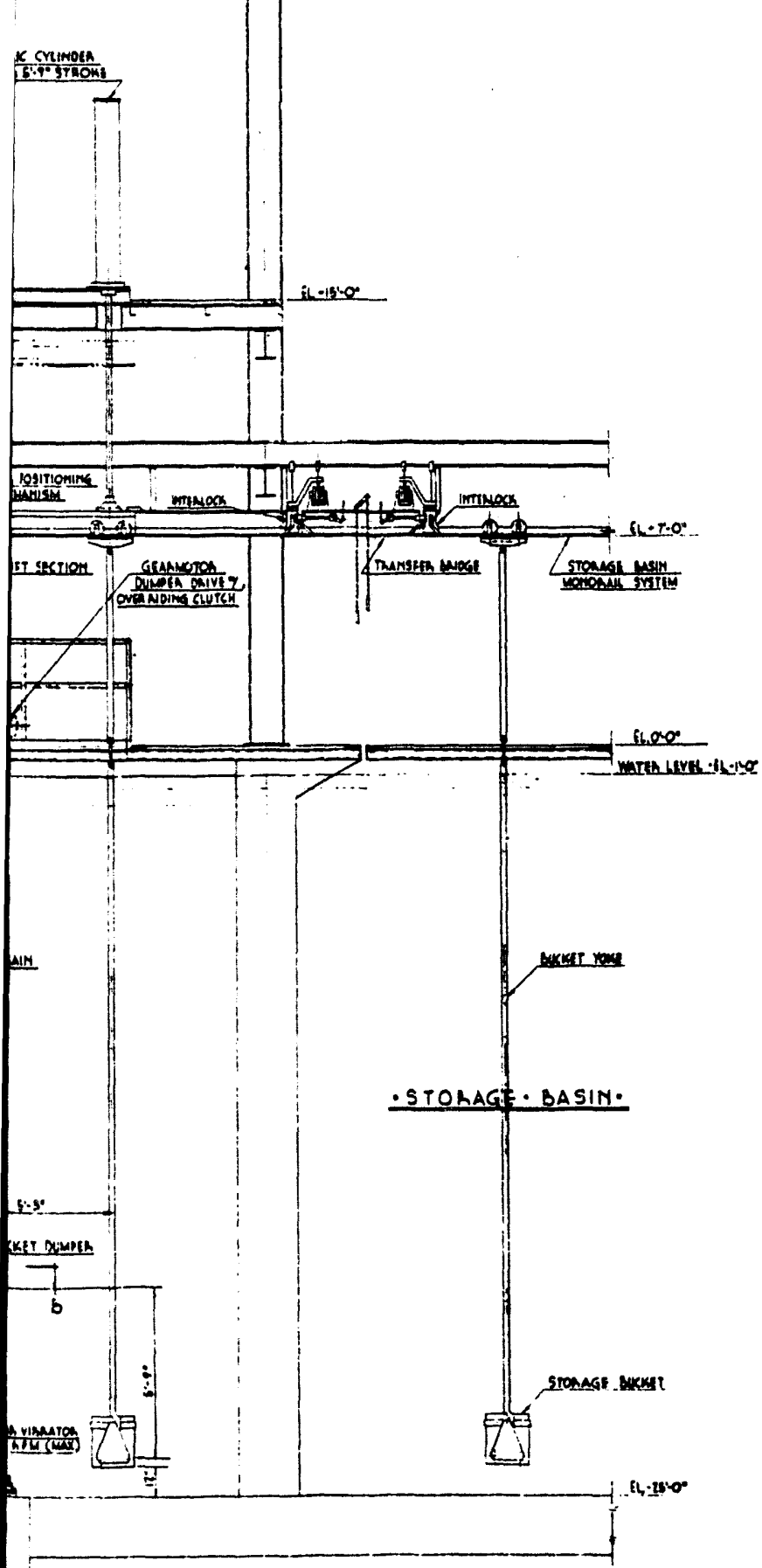

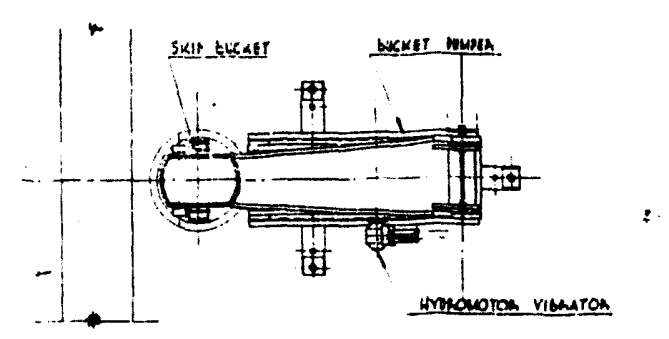

-SECTION " $B$ ' $B$ ".
HW 388381

FAGE 88
EDUIPMENT. NORAS.

1. STOAnge Bugset:

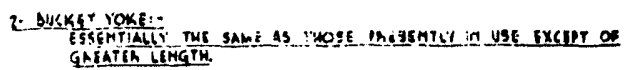

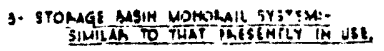

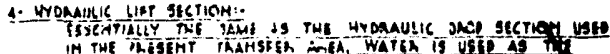
in THE Thistist Hionavilis :ivil

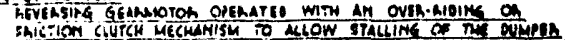

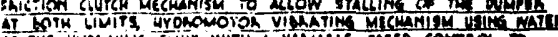

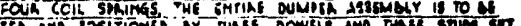

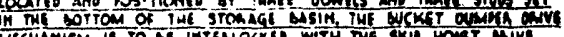
MEC ALA

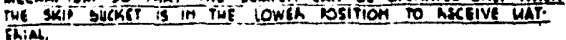

(c) - Skip vast-

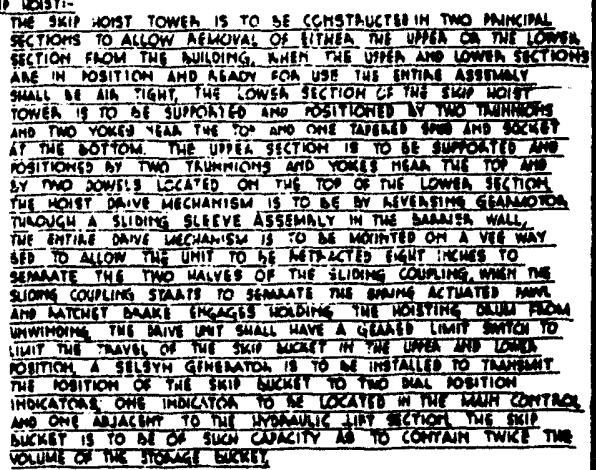




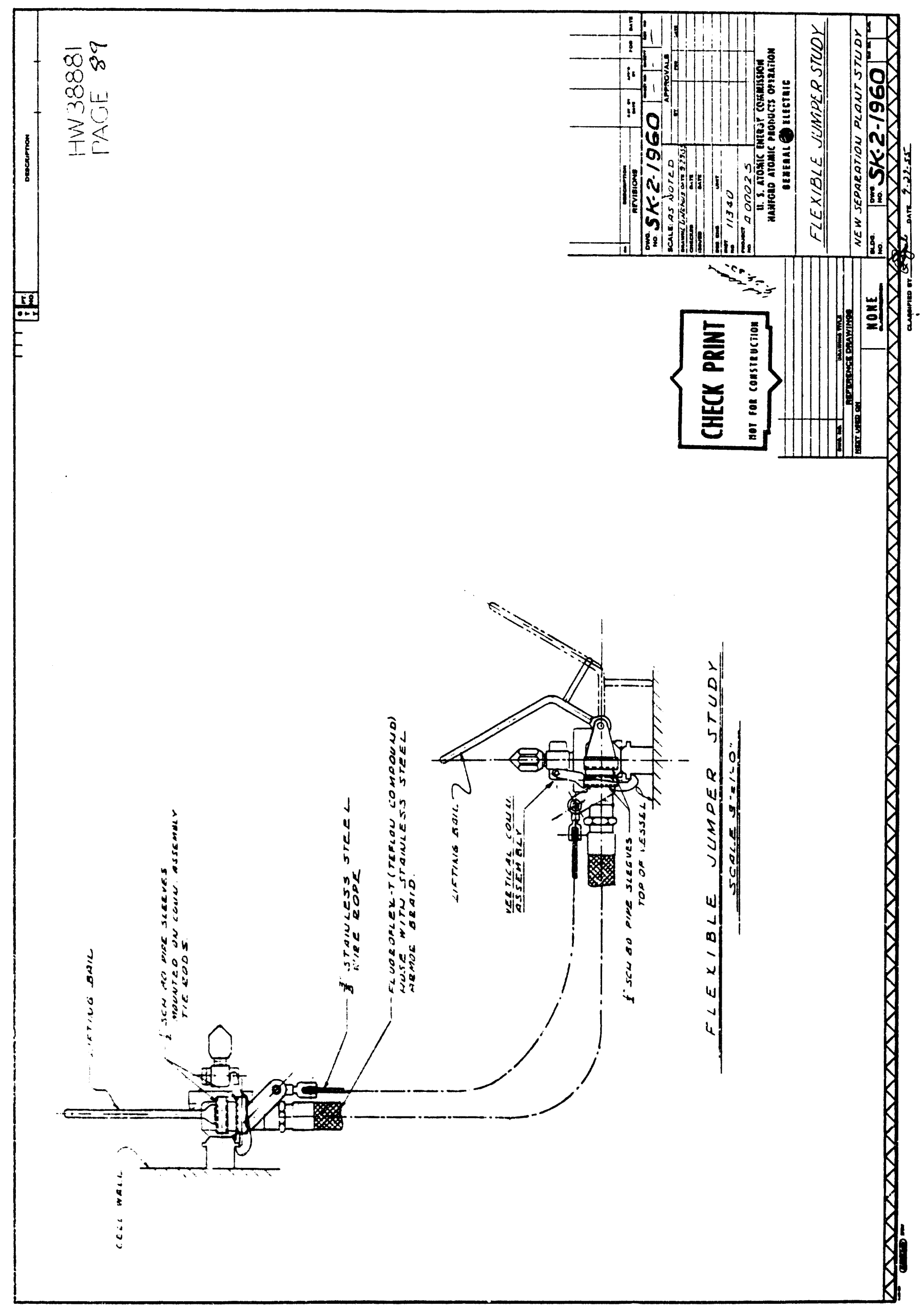




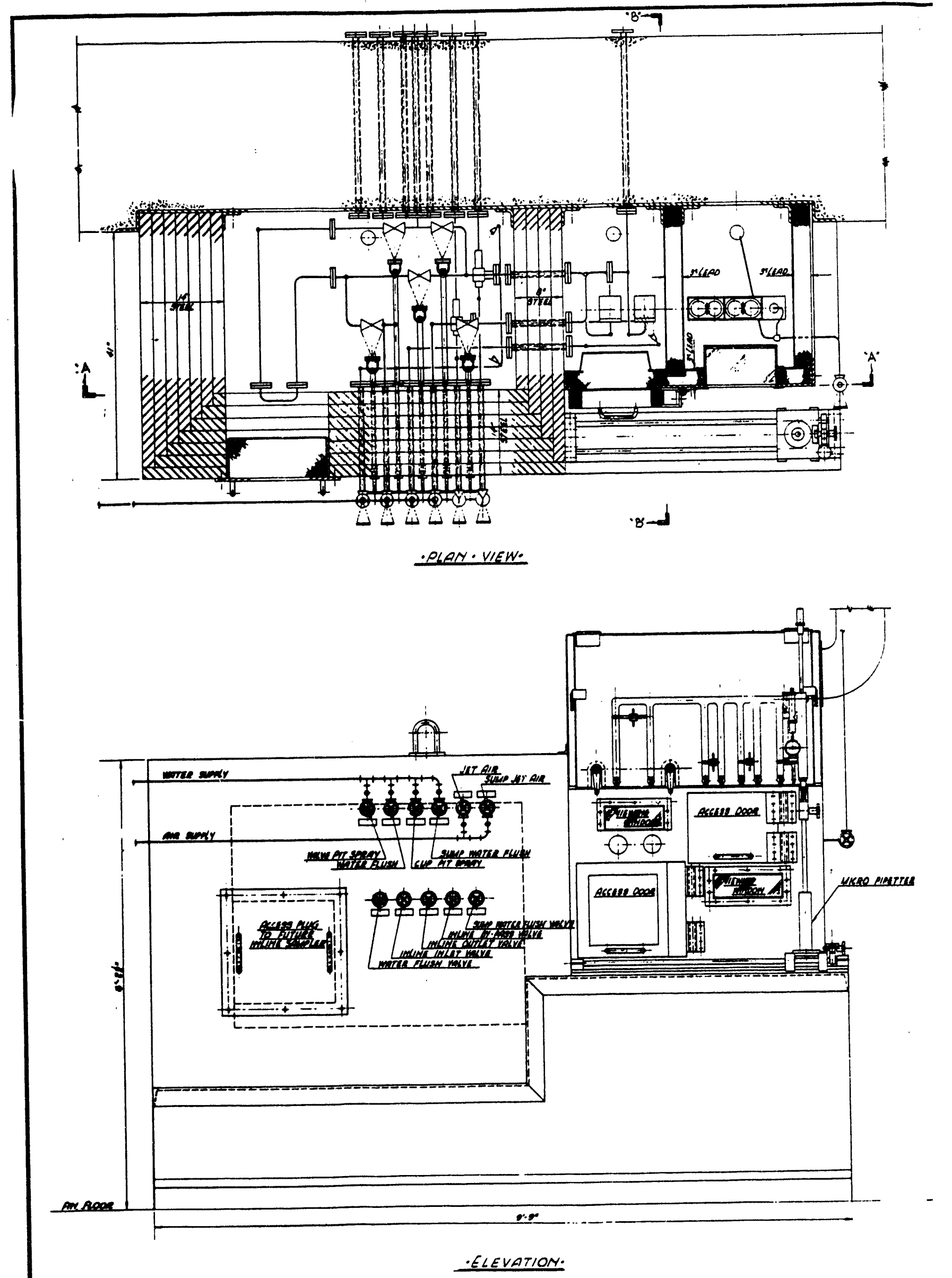




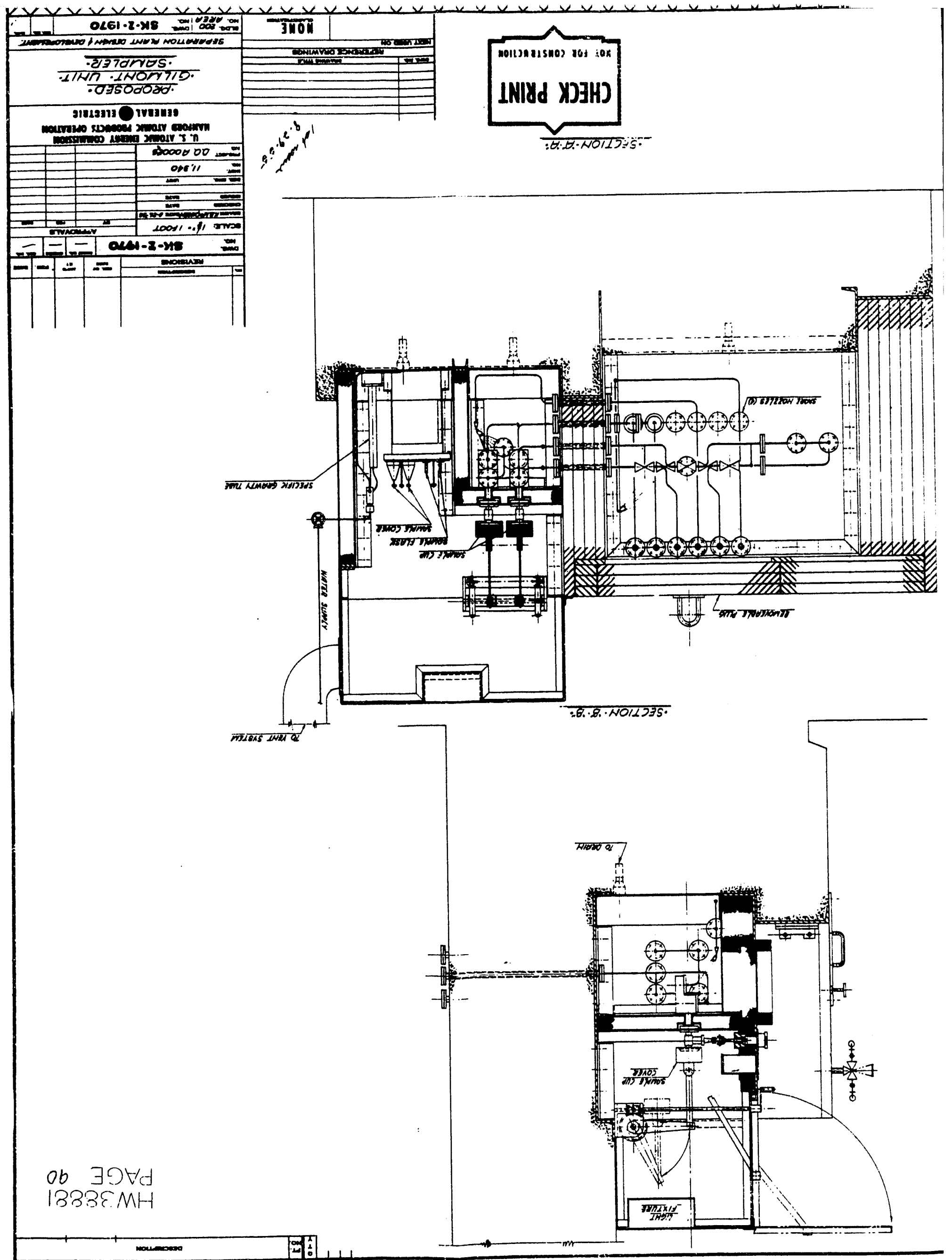


$H W-38881$

PAGE 91

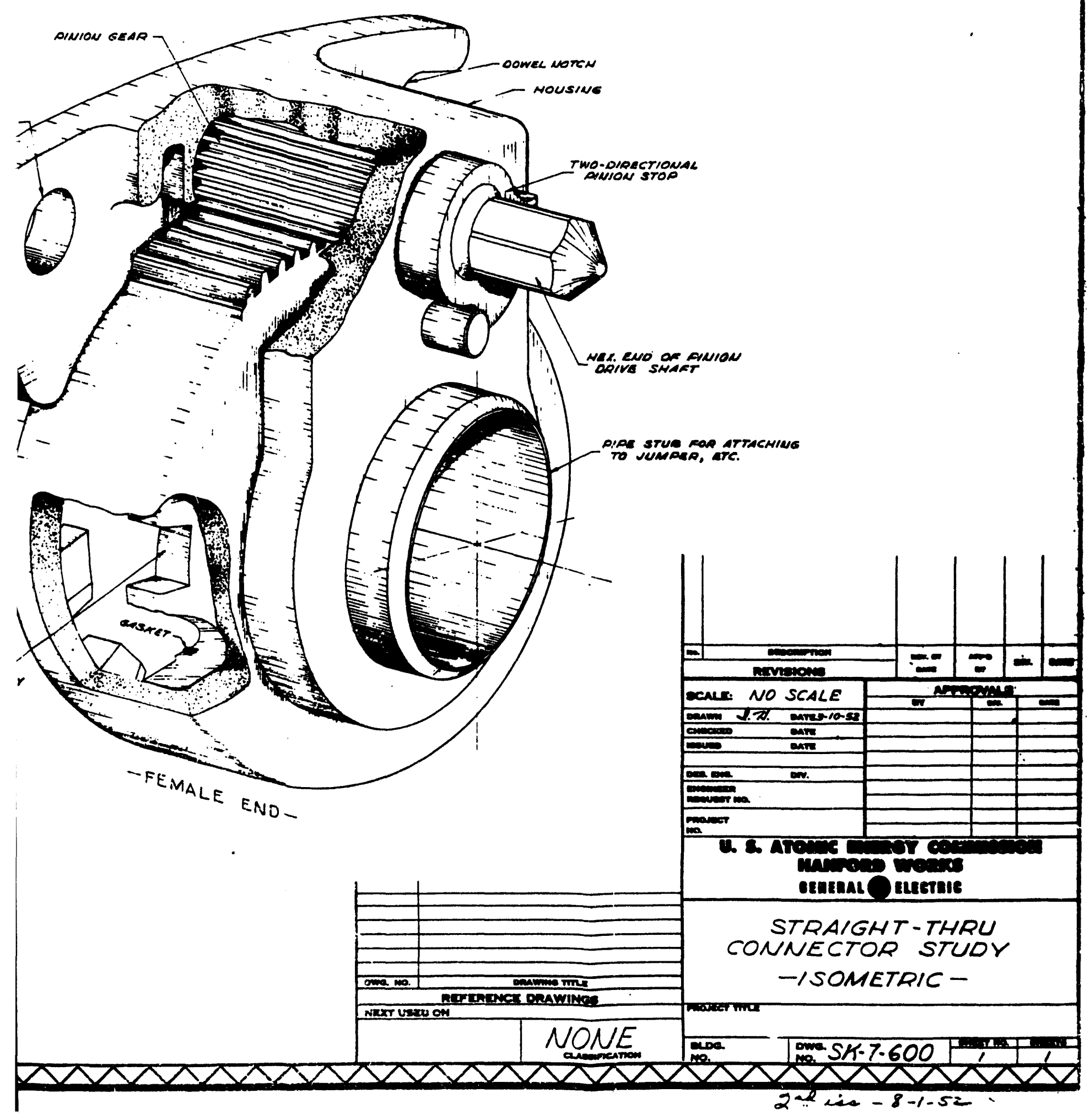




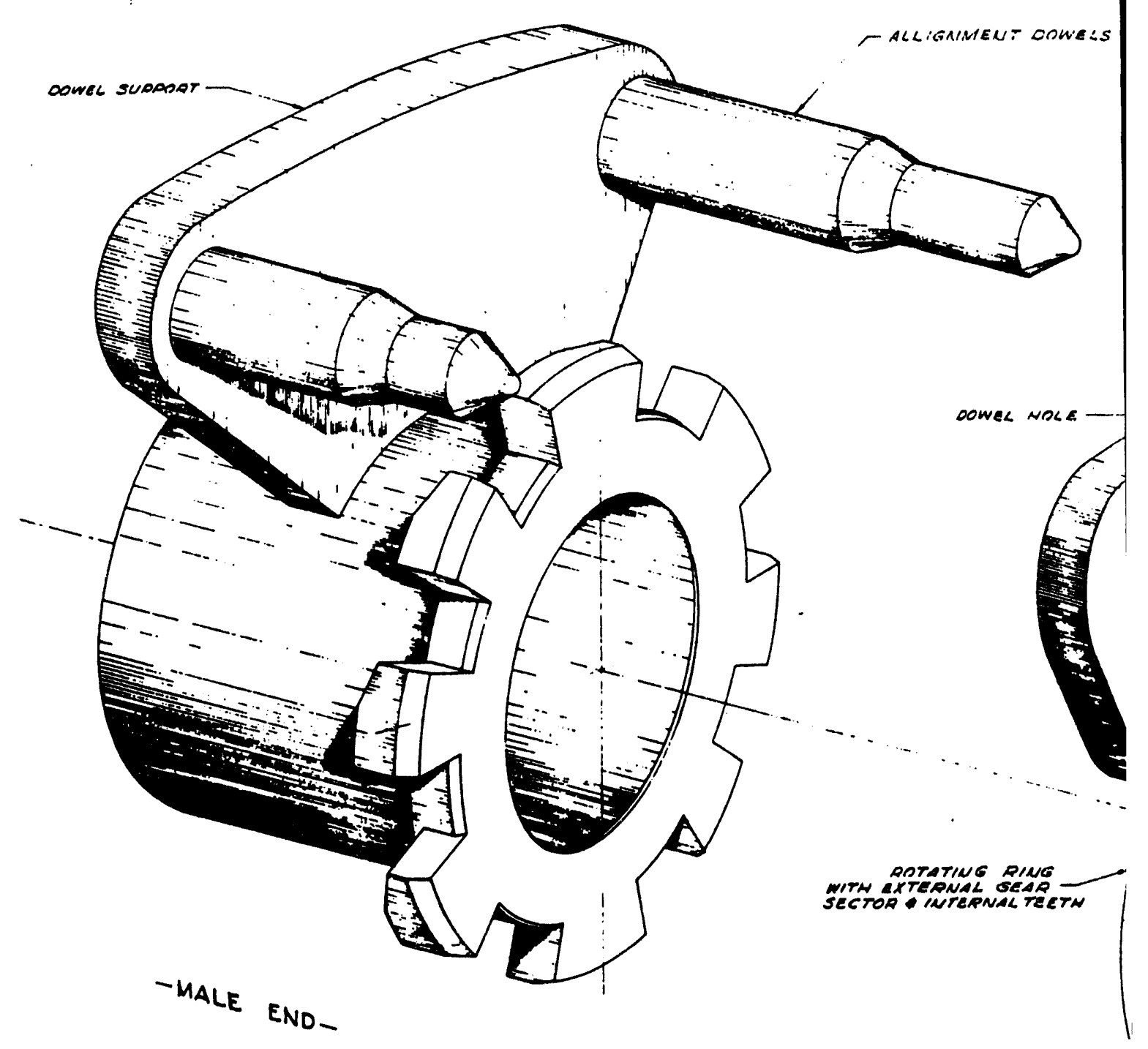

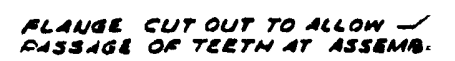



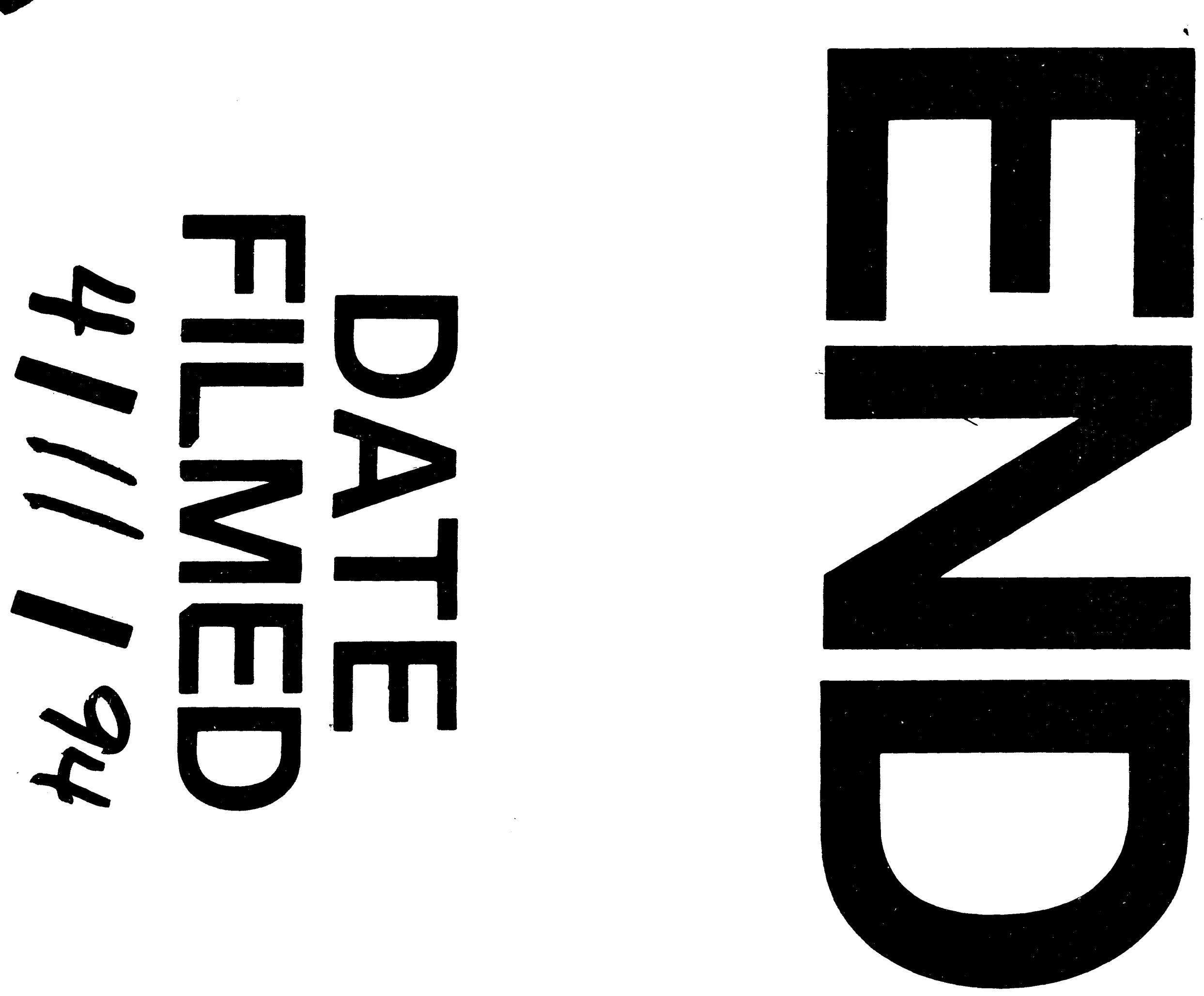
